1996

\title{
Jurisdiction in Cyberspace
}

Henry H. Perritt Jr.

Follow this and additional works at: https://digitalcommons.law.villanova.edu/vlr

Part of the Computer Law Commons

\section{Recommended Citation}

Henry H. Perritt Jr., Jurisdiction in Cyberspace, 41 Vill. L. Rev. 1 (1996).

Available at: https://digitalcommons.law.villanova.edu/vlr/vol41/iss1/1

This Symposia is brought to you for free and open access by Villanova University Charles Widger School of Law Digital Repository. It has been accepted for inclusion in Villanova Law Review by an authorized editor of Villanova University Charles Widger School of Law Digital Repository. 


\title{
VILLANOVA LAW REVIEW
}

VOLUMe 41

1996

NUMBer 1

\section{JURISDICTION IN CYBERSPACE*}

\author{
Henry H. Perritt, JR.**
}

\section{Table of Contents}

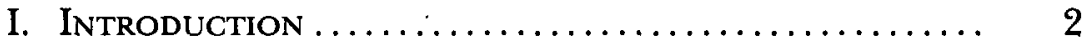

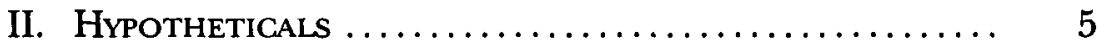

III. Relationship Among Personal Jurisdiction, Service of Process, Venue, Choice of Law, Enforcement of Judgments AND Discovery ................. 7

A. Introduction to Determinants of Judicial Power ....... 7

B. Historical Relationship Among Jurisdiction, Venue and Choice of Law......................... 9

IV. Personal Jurisdiction $\ldots \ldots \ldots \ldots \ldots \ldots \ldots \ldots \ldots \ldots . \ldots \ldots$

A. Personal Jurisdiction in Civil Cases............... 14

B. Obtaining Personal Jurisdiction over Publications ..... 17

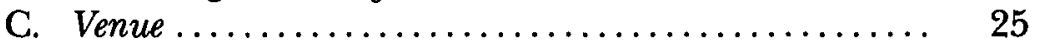

D. Service of Process and Attachment ............. 31

E. Personal Jurisdiction in Criminal Cases........... 35

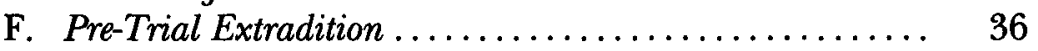

G. Extralegal Seizure..................... 39

H. Criminal Venue.......................... 42

V. Choice of Law ....................... 44

* This Article is available at the Villanova Law Review home page at http:// vls.law.vill.edu/academic/jd/journals/law-review/Volume_41/.

** Professor of Law, Villanova University School of Law. S.B. (Engineering), 1966, S.M. (Management), 1970, Massachusetts Institute of Technology;J.D., 1975, Georgetown Law Center; member of the bar: Virginia, Pennsylvania, District of Columbia, Maryland and United States Supreme Court. The author appreciates research assistance and brainstorming from his law clerks, Ryan Bornstein and Sean P. Lugg, Villanova Law School, Class of 1996, and good ideas from his friend, David R. Johnson, Esq. David Straite, also of the Class of 1996, had good ideas on organization and on new legal institutions. Some of the analysis developed in this Article appears in other forms in chapters 12 and 13 of the author's most recent book, LAW AND THE INFORMATION SUPERHIGHWAY (John Wiley \& Sons 1996), and in papers delivered at the September 22, 1995 meeting of the International Cryptographic Institute, on international search and seizure issues, and at the October 12,1995 , Open Days celebration of Oslo University, in Norway. 
A. Choice of Law in Civil Cases ................... 45

B. Extraterritorial Application of Criminal Statutes ...... 51

C. Enforcement of Foreign Criminal Law.............. 54

D. International Crimes........................ 55

VI. ENFORCEMENT OF JUDGMENTS .................. 58

A. Enforcement of Civil Judgments ................. 58

B. Geographic Scope of Injunctions .................. 64

C. Post-Conviction Extradition..................... 70

D. Forfeiture as Criminal Penalty ................. 71

VII. DiscoverY ................................. 72

A. Civil Discovery ......................... 73

B. Searches and Seizures of Electronic Materials ......... 79

C. Foreign Searches for Criminal Evidence ............ 82

D. Excluding Wrongfully Obtained Evidence ............ 90

VIII. New Legal Institutions $\ldots \ldots \ldots \ldots \ldots \ldots \ldots \ldots \ldots . . \ldots 9$

A. Arbitration ............................ 94

B. United States Court for Cyberspace............... 100

C. Development and Application of Private Rules for the GII .................................... 103

D. International Courts ....................... 106

E. Harmonizing International Search and Seizure Law.... 108

IX. Respective Roles of Civil and Criminal Law ........ 109

X. Conclusion ............................. 112

XI. ApPendix: International Computer Terrorism and THE INFORMATION INFRASTRUCTURE............... 116

\section{INTRODUCTION}

7 HE Global Information Infrastructure, also known as the "GII" or "Information Superhighway," links suppliers and users of electronic resources around the world, making it more difficult to localize wrongdoing for purposes of criminal or civil litigation. The same lack of localization makes it difficult to enforce judgments of criminal and civil courts, and to organize civil discovery and tools of criminal investigation, such as search warrants and subpoenas. Conduct with potentially serious legal consequences is difficult for traditional sovereigns to control in the GII because it is ephemeral, invisible and crosses geographic boundaries easily. Geographically based concepts of sovereignty must be squared with the nature of open networks, which are indifferent to geographic boundaries. Conventional doctrines of jurisdiction to prescribe, to adjudicate and to enforce legal decisions ${ }^{1}$ must evolve to handle new disputes

1. See Restatement (Third) of Foreign Relations Law $\S 8402-33$ (1987) (ex- 
in cyberspace.

Whose substantive legal rules apply to a defamatory message that is written by someone in Mexico, read by someone in Israel by means of an Internet server located in the United States, injuring the reputation of a Norwegian? Whose courts have jurisdiction to adjudicate claims of injury or violation of national rules? Must a Norwegian go to Mexico or to the United States to find a legal institution with power over one of the two potential sources of compensation? If not, and if jurisdiction exists in Norway, the most convenient forum for the victim, how is a favorable decision by a Norwegian tribunal ordering that the Mexican originator or the American intermediary pay damages to be enforced outside of Norway?

Similar questions, addressed by different rules, arise in the criminal context. Suppose the rnessage is criminal instead of defamatory, involving child pornography or indecency, or representing some sort of financial fraud, forgery or terrorism. Must the wrongdoer be tried only where he or she is physically found? If the answer is yes, how should the wrongdoer be apprehended and moved to the place of trial? Whose substantive criminal law should apply?

Arguably, in the hypothetical above, Norway has the greatest interest in punishing the conduct, while Mexico has only a weak interest, but legislatures usually focus on conduct occurring within the jurisdiction in defining crimes, and criminal courts rarely exercise power to prosecute for a crime against another jurisdiction's laws. While conflict of law jurisprudence has wrestled with problems like these for centuries, ${ }^{2}$ the transnational character of cyberspace will increase the frequency with which choice of law questions arise. Also, questions may arise as to the suitability of traditional choice of law formulations and their possible extension into the criminal context.

plaining three types of jurisdiction). Jurisdiction to prescribe implicates civil choice of law doctrines, and doctrines of universal crimes and extraterritorial application of criminal law. Id. $\$ \S 402-04$. Jurisdiction to adjudicate implicates personal jurisdiction and venue doctrines in the civil context, and extradition and trial in absentia doctrines in the criminal context. Id. $\$ \S 421-23$. Jurisdiction to enforce implicates judgment-enforcement doctrines and post-conviction extradition. Id. $\$ \S 431-33$.

2. See, e.g., Joseph Story, Commentaries on the Conflict of Laws ch. XIV (4th ed. 1852) (discussing conflict of laws jurisprudence); see also JOSEPH BEALE, Treatise on the Conflict of Laws (1916) (same); Brainerd Currie, Selected EsSaYs on the Conflict of Laws (1963) (same); Ulrich Huber, De Conflictum Legum Diversarum in Diversis Imperiis, in vol. II, Book I, title iii of Praelectrones JuRIS ROMANI ET HODIERNI (1689) (same). 
This Article explores how the legal system deals with information technology procedurally, beginning with well-recognized problems of civil and criminal jurisdiction, ${ }^{3}$ and discussing closely associated problems in choice of law, ${ }^{4}$ enforcement of judgments ${ }^{5}$ and discovery. ${ }^{6} \mathrm{Next}$, it explores new legal institutions designed to deal with the trans-border difficulties caused by the GII. ${ }^{7}$ Of the several jurisdictional problems, the problem of criminal jurisdiction is the most serious. In the civil sphere, personal jurisdiction and choice of law pose no insuperable difficulties, because there is growing agreement on the basic principles of both, which adequately accommodate most of the special circumstances of the GII.

Enforcement of civil judgments presents somewhat greater difficulty, because the international legal framework is not sufficiently comprehensive to allow parties confidence in enforcing a civil judgment in another country where assets may be located. Nevertheless, the availability of arbitration as an alternative dispute resolution forum, the decisions of which are nearly universally enforceable, provides a readily acceptable alternative to civil judgment enforcement. ${ }^{8}$

In contrast, the power of criminal courts is rigidly localized; they lack the flexibility afforded civil courts by the doctrine of personal jurisdiction supported by minimum contacts and choice of law. Criminal jurisdiction based on extradition treaties may not include computer crimes. Moreover, the power to conduct criminal searches and seizures across national boundaries is unevenly defined through the treaty process and foreign intelligence cooperative agreements, although the availability of civil discovery on the American model is similarly circumscribed.

The underlying transactions in the GII are not entirely new. International trade, international communications and international payments have been occurring for several hundred years. If changes in the legal system are needed to permit the GII to realize

3. For a discussion of civil and criminal jurisdiction problems, see infra notes 44-202 and accompanying text.

4. For a further discussion of choice of law issues, see infra notes 203-72 and accompanying text.

5. For a further discussion of enforcement of judgments, see infra notes 273355 and accompanying text.

6. For a further discussion of problems with civil and criminal discovery, see infra notes 356-477 and accompanying text.

7. For a further discussion of new legal institutions, see infra notes $478-530$ and accompanying text.

8. For a further discussion of the advantages and drawbacks of arbitration in cyberspace disputes, see infra notes $478-98$ and accompanying text. 
its potential, it must be because the new technologies for trade, communications and payments diminish the suitability of existing legal arrangements. The new technologies may make it more difficult to identify the time and place of legally significant events. Additionally, the new technologies may reduce the cost of transactions to the point where the cost of utilizing existing legal measures, including the cost of uncertainty with respect to outcomes, may become so important relative to the value of the transaction that they discourage commerce. Finally, the new technologies may open up international commerce to types of transactions that heretofore mostly occurred only within a single country. For these reasons; the GII will force the international legal community at least to modify the way in which it deals with transnational conflict.

\section{Hypotheticals}

A hypothetical illuminates the relationship between the various aspects of civil and criminal jurisdiction. Suppose someone in country $X$ operates a World Wide Web server on the Internet and intentionally makes false statements in Web pages accessible through this server for the purpose of inducing customers in Virginia to buy inferior merchandise through the server. The purposeful direction of the misleading statements to Virginia would, under World-Wide Volkswagen ${ }^{9}$ and $A s a h i,{ }^{10}$ support personal jurisdiction in a Virginia state court. ${ }^{11}$ Of course personal jurisdiction would not exist unless the actor were served with appropriate process, which probably would not include electronic notice alone under current rules. The doctrine of forum non conveniens, however, might lead to the dismissal of a Virginia action because witnesses and other evidence necessary to prove the mental state elements of the fraudulent misrepresentation are more likely to be found in country $X{ }^{12}$ Choice of law arguments would focus on the competing interests of country $X$ and Virginia. Virginia has legitimate interests in protecting its citizens from fraudulent misrepresentation, but country $X$ has an interest in discouraging fraudulent conduct by persons operating from within its territory while also allowing a sufficient ambit of legitimate or mistaken commercial

9. World-Wide Volkswagen Corp. v. Woodson, 444 U.S. 286 (1980).

10. Asahi Metal Indus. Co. v. Superior Court, 480 U.S. 102 (1987).

11. For a further discussion of personal jurisdiction, see Part IV, infra notes 44-202 and accompanying text.

12. There are also arguments, however, that evidence of injury in the reliance can be found in Virginia. 
activity. Virginia substantive law probably would be applied, although there is room for argument.

As to criminal prosecution, no court in Virginia would have personal jurisdiction over the actor unless the actor could be made physically available before the Virginia court. This could be accomplished through arrest while the actor is in Virginia, through extradition from country $X$, or from extra-legal physical seizure and transportation to Virginia followed by arrest there. Appropriateness of criminal venue in Virginia would depend on the commission of a crime in Virginia; the commission of a crime in country $X$ would be insufficient, unless the fraudulent misrepresentation through the Internet were viewed by Virginia law as an international "universal" crime like piracy. Most likely, a crime has been committed in Virginia only if the Virginia or federal criminal statutes against fraudulent misrepresentation of this sort (perhaps wire fraud or consumer fraud) have extraterritorial effect, in which case the Virginia targeting of the conduct in country $X$ probably would satisfy the effects test under international law and justify extraterritorial application of Virginia or federal criminal law to the conduct. Any civil discovery or search and seizure in country $X$ would depend on the cooperation of country $X$ officials in responding to U.S. requests.

Further, if there were less evidence that the purpose of the statement was to induce persons in Virginia, as opposed to persons in general, then there would be greater difficulty with personal jurisdiction in the civil case, and there also would be greater difficulty with substantive application of Virginia or federal law in the criminal case - the criminal equivalent of choice of law. Of course, the courts of country $X$ would have personal jurisdiction over the actor with respect to both civil and criminal litigation, but could entertain a prosecution only for violation of criminal laws of country $X$ (unless an international crime is involved as noted earlier in this section), or unless the criminal jurisprudence of country $X$ allows prosecution of a citizen of country $X$ for violating foreign law (a relatively unlikely prospect, though one that enjoys some case law support in France and Germany). In the civil case, the courts of country $X$ would apply country $X$ choice of law rules, which probably do not differ materially from those that would be applied by a court sitting in Virginia. If the actor were an American citizen, that would give the courts in Virginia a stronger basis to exercise personal jurisdiction in the criminal prosecution, but that citizen or she still could not be tried in absentia. 
Finally, the analysis would be essentially the same, if, for instance, the conduct involved intentional public distribution of pirated material, infringing the copyright of a citizen of Virginia, except that the civil action would be for copyright infringement instead of fraudulent misrepresentation, and the criminal prosecution would be for criminal copyright infringement. There is no reason that the outcome on any of the dimensions of civil or criminal jurisdiction would be different, although the availability of the many reported cases could make resolution of the civil personal jurisdiction and choice of law questions more certain. Also, congressional intent with respect to extraterritorial jurisdiction might be different as between the copyright crime and the wire fraud or consumer fraud crimes. These hypotheticals illustrate the problems created by the GII. The contours of these problems, as well as some possible solutions, are explored below.

III. Relationship Among Personal Jurisdiction, Service of Process, Venue, Choice of Law, Enforcement of JudGMENTS AND DiscoverY

Criminal and civil jurisdiction proceed from common concepts, although the detailed requirements are significantly different in modern law. The two sections in this part explain the conceptual relationship among different aspects of the power of courts over controversies, comparing and contrasting civil and criminal doctrines, historically and in modern law.

\section{A. Introduction to Determinants of Judicial Power}

Four procedural doctrines interact in circumscribing the power of any court to decide a controversy according to particular substantive rules: personal jurisdiction; notice by arrest, service of process or otherwise; choice of law; and venue. A fifth doctrine, enforcement of judgments, encompasses all of the other four. The res judicata effect of a judgment, and therefore its enforceability, ${ }^{13}$ depends on the court rendering the judgment having personal jurisdiction, being the appropriate venue and giving appropriate notice to those bound by the judgment. Inappropriate choice of law

13. There may be other limitations on enforceability, based, for example, on the absence of a procedural scheme for enforcing foreign judgments (such as with Sweden). Recognition remains a threshold requirement, however, for enforcing foreign judgments, and is available only for final judgments, in other words, those with res judicata effect. 
also is a basis for challenging the efficacy of a judgment, albeit a much weaker one.

The four doctrines were not particularly distinct in early English procedure, ${ }^{14}$ but later diverged in nineteenth century and early twentieth century American jurisprudence. Now, they are beginning to converge again in civil procedure (though not in criminal procedure) ${ }^{15}$ The fair play and substantial justice test for personal jurisdiction ${ }^{16}$ requires interest analysis similar to that used to resolve choice of law disputes. It also overlaps considerably with forum non conveniens analysis used to determine venue. More

14. Blackstone explains that the first process for personal writs for injuries not against the peace was a summons. 3 WiLliam Blackstone, COMMENTARIES *279. If the defendant disobeyed "this verbal monition," the next process was by writ of attachment, followed in turn by a writ of distress. Id. at $* 280$. If the defendant still failed to respond, he would be "gradually stripped of . . . all [property] by repeated distresses, till [sic] he rendered obedience to the King's writ; and, if he had no substance, the law held him incapable of making satisfaction, and therefore looked upon all further process as nugatory." Id. at *281. For cases of injury accompanied by force, the law also provided for process against the defendant's person if he neglected to appear on the process of attachment, through capias ad respondendum. $I d$. In addition, for cases of peaceable but fraudulent injuries, capias also was allowed, gradually expanding until "a capias might be had upon almost every species of complaint." Id. at *282. Because this process was served by the sheriff's deputies called "summoners," there is every reason to infer that process could not be served beyond the territorial limits of that particular sheriff. If process could not be served, there was no way to bring the defendant within the jurisdiction of courts. As to arrest, Blackstone says that a warrant from a justice of the court of King's bench "extends all over the kingdom... . But the warrant of a justice of the peace in one county, [such] as Yorkshire, must be backed, that is, signed, by a justice of the peace in another, [such] as Middlesex, before it can be executed there." 4 William Blackstone, Commentaries *291-92.

15. See generally Harold G. Maier \& Thomas R. McCoy, A Unifying Theory for Judicial Jurisdiction and Choice of Law, 39 Ам. J. CoMP. L. 249, 280-90 (1991) (finding that constitutional limits on personal jurisdiction can also serve as appropriate limits on choice of law, but only if general jurisdiction is abolished); Linda J. Silberman, Reflections on Burnham v. Superior Court: Toward Presumptive Rules of Jurisdiction and Implications for Choice of Law, 22 RutGers L.J. 569, 584-85 \& nn.75-80 (1991) (noting that relaxed personal jurisdiction rule leads to uncertainty because of relatively few constitutional limitations on choice of law rules). In Judge Silberman's view, the choice of forum in many cases determines the outcome because courts tend to prefer their own substantive law or because their choice of law rules are different. Id. at 585 n.76. See also Allan R. Stein, Forum Non Conveniens and the Redundancy of Court-Access Doctrine, 133 U. PA. L. REv. 781, 784-85 (1985) (stating that relaxation of personal jurisdiction and venue rules has led to greater reliance on forum non conveniens as unpredictable and essentially unreviewable way of limiting forum choice). Professor Stein argues that the distinctions among subject matter jurisdiction, personal jurisdiction, venue and forum non conveniens are not sufficiently clear to justify current differences in doctrine. He urges decreased reliance on forum non conveniens as a means of allocating political authority and proposes a return to jurisdictional rules "that reflect the policy choices currently made in the guides of forum non conveniens dismissals." Id. at 786.

16. For a further discussion of the fair play and substantial justice test, see infra notes 45-61 and accompanying text. 
flexible rules for personal jurisdiction necessitate an expansion of the types of notice that are acceptable. ${ }^{17}$ Venue rules also interact with choice of law rules. Choice of law analysis usually begins with the forum's choice of law rule; thus, venue may determine the outcome of choice of law. 18

As commerce, and therefore litigation, becomes more international in character, American personal jurisdiction, venue, choice of law and notice rules must be reassessed and perhaps harmonized with corresponding rules in other countries. ${ }^{19}$ Analysis and harmonization can be simplified if the convergence eventually results in the atrophy of independent personal jurisdiction inquiry, replaced by stronger forum non conveniens rules and clearer limitations on choice of law. ${ }^{20}$ International reassessment and harmonization of criminal jurisdiction must take place in the context of ongoing efforts to define codes of international crimes and to develop concepts for international criminal courts.

\section{B. Historical Relationship Among Jurisdiction, Venue and Choice of Law}

The prospects for unifying personal jurisdiction, venue and choice of law rules are influenced by the historical separation of the rules, and their historical links to private international law concepts. Historically, venue rules not only determined where a suit

17. When the limits of jurisdiction are the physical boundaries of a sovereign entity, notice can be confined to in-hand service of process. When the limits of personal jurisdiction cross physical boundaries, mail service and constructive service by publication become necessary.

18. Moreover, in the federal system where forum non conveniens analysis may result in the transfer of a case to another district court under 28 U.S.C. $\$ 1404$ (1994), the choice of law rule of the original court must be used by the transferee court. See Ferens v. John Deere Co., 494 U.S. 516 (1990) (extending \$1404(a) rule to transfer initiated by plaintiff).

19. See generally Linda J. Silberman, Developments in Jurisdiction and Forum Non Conveniens in International Litigation: Thoughts on Reform and a Proposal for a Uniform Standard, 28 TEx. INT'L L.J. 501 (1993) (noting that procedural idiosyncracies attract international litigants to U.S. courts, and substantive rules in antitrust and products liability areas attract plaintiffs, requiring frequent application of personal jurisdiction and choice of law rules in marginal cases, and also challenging judgment enforcement rules except when foreign defendants have assets in United States).

20. See id. at 584-90 (acknowledging proposals and implementation in Australia, as well as objective basis for rejecting transient jurisdiction, but expressing concern that limited review of venue decisions and lack of clear constitutional restraints on choice of law would make nationwide service of process undesirable) (citing Russell J. Weintraub, An Objective Basis for Rejecting Transient Jurisdiction, 22 RutGers L.J. 611 (1991)). 
could be brought, subsuming personal jurisdiction inquiries, ${ }^{21}$ but also determined what law would be applied. Until Pennoyer $v$. Neff, ${ }^{22}$ territorial limitations were imposed mostly by state (or national) venue statutes. Venue, in turn, depended on whether the cause of action was "local" or "transitory." Local causes of action had only one acceptable venue, while transitory causes of action might have several. All crimes except piracy were local. Choice of law meanwhile was hardly an issue; it was assumed that any court would apply its own substantive law. Choice of venue thus determined choice of law. ${ }^{23}$ There was, under these early formulations, little difference between criminal and civil jurisdiction and venue. For both civil and criminal cases, courts exercised jurisdiction only over those physically before the court. ${ }^{24}$ Once a court had jurisdiction over the defendant, it applied its own substantive law.

One of the best explanations of the original relationship among venue, personal jurisdiction and enforcement is found in Livingston $v$. Jefferson, ${ }^{25}$ a trespass action against Thomas Jefferson. The alleged trespass occurred in New Orleans, and Jefferson was found in Virginia. The Virginia circuit court dismissed the action, finding that it was local and therefore could be brought only where the trespass occurred. ${ }^{26}$ Jefferson was not found in that district and

21. Of course, service of process also was necessary. Sir John Fortesque describes the English jury process as involving a kind of reference from the common law courts to the sheriff of a particular county who assembles a jury from the "where the fact is suppose to be." Sir John Fortesque, De Laudibus Legum ANGLAE 85 (Francis Gregor trans., 1847). In chapter 26, he explains that the jury heard evidence presented by the parties and then retired to agree on a verdict. Id. at 91-93. But see Stein, supra note 15, at 781, 788 (distinguishing venue from personal jurisdiction; noting that venue relates to appropriate place for trial within given jurisdiction, while personal jurisdiction represents allocation of judicial power among different sovereign jurisdictions). Professor Stein acknowledgesindeed he argues - that sharply distinguishing venue as involving private privilege from jurisdictional rules involving political power is misplaced. Id. at 793. Professor Stein also acknowledges that the distinction at common law between venue and jurisdiction was not altogether clear. Id. at 798.

22. 95 U.S. 714 (1877). Pennoyer constitutionalized personal jurisdiction by making it clear that the U.S. Constitution imposes territorial limits on the exercise of judicial power by state courts. Id. at 722-30.

23. See A.E. Anton \& Paul R. Beaumont, Private International Law 18 (2d ed. 1990) (stating assumption that choice of judge determined law had to be relaxed as trade spanned boundaries of traditional sovereigns, while intellectual justifications had to be developed for applying foreign law).

24. This was true only in the earliest days of English procedure. See XVI INternational. EnCyclopedia of Comparative Law Civil Procedure ch. 2 (1982) (noting English preoccupation with obtaining presence of defendant in civil cases, reinforced by sophisticated essoins).

25. 15 F. Cas. 660 (C.C.D. Va. 1811) (No. 8,411).

26. Id. at 662 . 
therefore could not be sued there. Under the prevailing analytical framework, he apparently could not be sued anywhere. Nevertheless, both John Marshall, sitting as Circuit Justice, and Judge Tyler agreed that the rule was long established that trespass actions were local rather than transitory, thereby limiting venue to Louisiana. ${ }^{27}$

As important as the holding is, the explanations offered by Chief Justice Marshall and Judge Tyler are even more illuminating. In trespass actions, Marshall explained, the title and bounds of land might come into question, and only a jury from the vicinage of the land could appropriately determine such facts. ${ }^{28}$ Judge Tyler reasoned that a judgment for the plaintiff would potentially necessitate execution by the sheriff and his posse to remove the trespasser, if necessary: "And suppose the sheriff and jury should deny the power of the court, could they be coerced?" 29 In other words, the power of the court should be circumscribed by the court's power over the officer that must execute the court's judgment. ${ }^{30}$ If execution could be had only in one place, then only the court of that place had the power to try the case. ${ }^{31}$ Judicial power was limited both by convenience analysis (proximity to the subject matter of suit), the focus of modern venue analysis, and also by considerations of judgment enforceability.

Transitory actions were different. For them, venue existed more or less wherever the defendant could be found. Contract was the archetypal transitory action, based on a legal and moral obligation in the person to perform his promises, and such actions thus were not tied to any particular place. ${ }^{32}$ There was a loose correspondence between real actions and local actions, and between personal actions and transitory actions. When enforcement required

27. Id. at 662-65; see also Reasor-Hill Corp. v. Harrison, 249 S.W.2d 994, 995-96 (Ark. 1952) (reviewing rationale for Livingston $v$. Jefferson and concluding that basis for distinguishing local and transitory actions no longer made sense, in part because courts easily could obtain knowledge of legal rules applicable in jurisdictions where land lies). Tax claims were another prominent example of purely local claims. The courts in England, for example, would not entertain a claim by France for taxes due in France. But by the mid-1950s, the rule had begun to erode, at least with respect to interstate jurisdiction within the United States. See Oklahoma v. Neely, 282 S.W.2d 150, 152 (Ark. 1955) (explaining why rule originally may have made sense, but did not any longer).

28. Livingston, 15 F. Cas. at 663 (Marshall, J.). Early juries used their own knowledge of the facts as well as testimony adduced from witnesses.

29. Id. at 662 (Tyler, J.).

30. Similar issues of control arise in the extraterritorial enforcement of injunctions. For a further discussion of these issues, see infra notes 307-45 and accompanying text.

31. Livingston, 15 F. Cas. at 662 (Tyler, J.).

32. Id.; accord, id. at 664 (Marshall, J.). 
doing something with respect to a res, only the local sheriff could do it. Conversely, when enforcement involved a person who might move around, enforcement could occur wherever the person was found, through imprisonment for debt, or simply through a "capias ad satisfaciendum"33 or "capias ad respondendum." 34

These limitations, however, were purely common-law limitations. ${ }^{35}$ The distinction between real and personal actions achieved constitutional status in Pennoyer ${ }^{86}$ some sixty-six years later, in which an action proceeded as though it were personal when the remedy sought was in rem. ${ }^{37}$ In Pennoyer, the United States Supreme Court reasoned that the territorial limits on the power of state courts are like the territorial limits on the power of courts in nation-states. If a sovereign purported to decide a personal action when it lacked the power to serve process on the person of the defendant, its judgments were not entitled to recognition or enforcement in other states. $^{38}$ Conversely, the same court could exercise power over a real action because it had de facto power over the res located within its territorial limits. ${ }^{39}$ Of course, an important feature of this distinction was that an in rem judgment could be enforced only to the limits of the value of the thing. ${ }^{40}$ The Pennoyer Court held that purporting to decide cases against persons not within the personal jurisdiction of the court violated due process under the Fourteenth Amendment. ${ }^{41}$

33. A capias ad satisfaciendum is a writ of execution calling for the arrest of a judgment debtor in order to compel him to satisfy the judgment. See Perlmutter v. DeRowe, 274 A.2d 283, 286 (N.J. 1971).

34. A capias ad respondendum is a judicial writ directing the sheriff to arrest the defendant and bring him into court to answer a complaint filed against him. See Vermont Nat'l Bank v. Taylor, 445 A.2d 1122, 1124 (N.H. 1982) (quashing ex parte capias procedure used to initiate civil contempt proceeding).

35. Livingston, 15 F. Cas. at 663-65 (Marshall, J.) (emphasizing role of English common law in Virginia).

36. Pennoyer v. Neff, 95 U.S. 714 (1877).

37. See id. at 720 . The Court commented:

[T] he property here in controversy sold under the judgment rendered was not attached, nor in any way brought under the jurisdiction of the court. Its first connection with the case was caused by a levy of the execution. It was not, therefore, disposed of pursuant to any adjudication, but only in enforcement of a personal judgment, having no relation to the property, rendered against a nonresident without service of process upon Id. him in the action or his appearance therein.

38. Id. at 729-30.

39. Id. at 730-31.

40. Id. at 731-32 (citing Kilboum v. Woodworth, 5 Johns. 37 (N.Y. 1809) (holding judgment and action for jurisdiction obtained by attachment of bedstead could not exceed value of bedstead)).

41. Id. at 733. But see id. at 734-35 (exempting status decisions such as divorce 
The distinctions between personal and real actions and between local and transitory actions have largely disappeared from personal jurisdiction analysis for civil actions. Further, the inherently non-local nature of information technology might seem to make the distinction entirely irrelevant in analyzing civil procedure issues for the GII, but that is not so. The traditional distinction between local and transitory actions appropriately sought to conform doctrine to practical limits on judicial power. The rationale used by Judge Tyler in Livingston is a good example. Even though interests analysis is the centerpiece of the law of personal jurisdiction ${ }^{42}$ and choice of law analysis, ${ }^{43}$ the pragmatic power dimension, along with an assessment of efficiency and convenience, becomes more important in deciding, as a practical matter, where a lawsuit over electronic conduct should be litigated and where judgments resulting from such a lawsuit can be enforced practicably. The simple answer, as in Livingston and Pennoyer, is that judicial power may be exercised over the GII wherever a human defendant may be found and wherever some assets are located. The GII may span geographic boundaries, but its human actors are present in some traditional jurisdiction, and the hardware, software and financial assets used to operate each part of the GII are located in some traditional jurisdiction. Lawsuits will be efficacious in those jurisdictions. The practical interaction between judicial power and electronic actors and assets appropriately guides application of modern personal jurisdiction, choice of law, venue and enforcement doctrines considered in the next several sections.

\section{Personal Jurisdiction}

Personal jurisdiction in both the criminal and civil context is the basic precondition of jurisdiction to adjudicate. Personal jurisdiction refers to the power of a court over the defendant. As the historical sections of this Article explain, personal jurisdiction originally derived from physical control or custody over the defendant. It has been relaxed in the civil context to allow power to be asserted over persons with certain connections with the forum state who are given formal notice through service of process. In the criminal context, however, personal jurisdiction still signifies physical custody.

and requirements that nonresidents consent to jurisdiction and appoint agents for service of process).

42. For a further discussion of personal jurisdiction, see infra notes 44-202 and accompanying text.

43. For a further discussion of choice of law, see infra notes 203-72 and accompanying text. 
Exploring application of personal jurisdiction concepts in cyberspace requires review of the "minimum contacts" and "fair play and substantial justice" concepts of civil personal jurisdiction, initially articulated in International Shoe, ${ }^{44}$ an understanding of the forum non conveniens doctrine that sometimes pretermits exercise of personal jurisdiction when it exists; and the various techniques, including extradition and extralegal obtaining of custody that extend into the international sphere, involved in criminal personal jurisdiction.

\section{A. Personal Jurisdiction in Civil Cases}

Personal jurisdiction of an American court, state or federal, depends on the interaction of an affirmative statutory or common law source of jurisdiction and limitations imposed by constitutional due process. Traditionally, as the preceding section explains, state courts asserted jurisdiction over persons physically present within their territorial boundaries and served with process while they were there, and asserted jurisdiction over things found within their territorial boundaries and attached while they were there. ${ }^{45}$

These affirmative bases of jurisdiction are constitutionally permissible merely because they are traditional under the Supreme Court's decision in Burnham v. Superior Court. ${ }^{46}$ But states, in addi-

44. International Shoe Co. v. Washington, 326 U.S. 310 (1945).

45. STORY, supra note 2 , $\$ \$ 532-38$, at 900-05. Personal jurisdiction in Roman law, for example, was limited to the domicile of the defendant except for in rem actions which could be brought where personal or real property was situated. Id. Jurisdiction also existed in the place where the contract was made or was to be fulfilled, if the defendant or his property could be found there, even if it was not the place of his domicile. Id. "Considered in an international point of view, jurisdiction, to be rightfully exercised, must be founded either upon the person being within the territory, or upon the thing being within the territory; for, otherwise, there can be no sovereignty exerted." Id. $\$ 539$, at 905 . Story noted questions about quasi in rem jurisdiction. Proceeding against nonresidents by attaching property found within the jurisdiction is not personally binding on the party as a judgment in personam; "it only binds the property seized or attached ... and is in no just sense a decree or judgment, binding upon him beyond that property. In other countries, it is uniformly so treated, and is justly considered as having no extraterritorial force or obligation." Id. $\$ 549$ at 921-22. See, e.g., 28 U.S.C. $\$ 1655$ (1994) (federal in rem jurisdiction); Colo. R. Crv. P. 4(e), (f) (1), (f) (2) (personal jurisdiction); Colo. R. Crv. P. 4(f) (3) (in rem jurisdiction); IowA R. Crv. P. 56.1 (personal jurisdiction); see also Stein, supra note 15, at 798-99 (describing early British practice as contemplating worldwide power of King's court, but limited by inability to enter default judgment against persons not present, which in turn was mitigated by distraint of property; venue was determined initially by location of King, and later by need for jury familiar with facts and controversy). Professor Stein also explains the early distinction between transitory and local causes of action. Id.

46. 495 U.S. 604 (1990). There is some doubt about the effect of the Burnham case, because the rationale stated in the text was embraced by only four justices. Id. Therefore, one must be careful in characterizing the holding of Bumham. The Scalia opinion, emphasizing the traditional basis of physical pres- 
tion to asserting jurisdiction over persons or things found within the forum state, also frequently assert jurisdiction in other cases under long arm statutes. ${ }^{47}$ Typical of long arm statutes are the provisions of the Uniform Interstate and International Procedure Act, ${ }^{48}$ which authorizes jurisdiction over persons served (usually by mail ${ }^{49}$ ) out-of-state when they have certain connections with the forum state. Long arm statutes typically authorize the exercise of jurisdiction to the extent permitted constitutionally $y^{50}$ under a line of Supreme Court cases beginning with International Shoe. 51

Under this line of cases, jurisdiction over a person or a corporation not served with process within the jurisdiction is permissible, but only when the defendant has minimum contacts with the forum state ${ }^{52}$ and only when the assertion of jurisdiction satisfies considerations of fair play and substantial justice. ${ }^{53}$ Within this analytical

ence, enjoyed the support of four justices: Justice Scalia, Chief Justice Rehnquist, Justice Kennedy and Justice White. Id. The competing view that would have validated jurisdiction based on minimum contacts analysis, without any particular weight given to the traditional character of the jurisdictional basis, similarly only enjoyed the support of four justices: Justices Brennan, Marshall, Blackmun and O'Connor. Id. at 606. See Silberman, supra note 19, at 569 (characterizing "two competing views that predominated" following Bumham).

47. See Unif. Interstate \& Int'l Procedure Act, 13 U.L.A. 355 (1986) (adopted by Arkansas, District of Columbia, Massachusetts, Michigan, Pennsylvania and Virgin Islands).

48. Id.

49. The growing use of digital information technologies introduces the possibility of electronic service of process, including telex, fax and e-mail, although these methods of service are not yet countenanced widely. For a further discussion of electronic service of process, see infra notes 134-39 and accompanying text.

50. The Constitution is a limit on personal jurisdiction, while long arm statutes affirmatively grant jurisdiction. The Constitution influences drafters of long arm statutes because they want to draft a statute that does not go beyond what the Constitution allows and thus be vulnerable to constitutional attack.

51. 326 U.S. 310 (1945).

52. See id. at 316; see also Shaffer v. Heitner, 433 U.S. 186, 204 (1977) (assessing defendant's minimum contacts by focusing on "the relationship among the defendant, the forum, and the litigation").

53. See, e.g., Asahi Metal Indus. Co. v. Superior Court, 480 U.S. 102 (1987) (explaining interaction of minimum contacts and fair play and substantial justice). The best way to combine the two considerations is to realize that when minimum contacts analysis results in a close question, fair play and substantial justice factors should have greater weight. The fair play and substantial justice part of the inquiry sometimes is called the Gestalt inquiry. It considers five factors:

(1) the burden on the defendant;

(2) the forum state's interest in adjudicating the dispute;

(3) the plaintiff's interest in obtaining the most efficient resolution of the controversy;

(4) the interstate judicial system's interest in the most efficient resolution; and

(5) the shared interest of the several states in furthering fundamental substantive social policies. 
framework, contacts such as sending goods into the forum state or permitting instrumentalities that cause injury to enter the forum state count as minimum contacts only if they are purposeful; mere foreseeability of contact with the forum state is not enough. ${ }^{54}$ Also, entering into a contract with someone in the forum state may satisfy minimum contacts requirements when the contract provides for a repetitive series of transactions with the forum state. ${ }^{55}$

Personal jurisdiction analysis in Europe places less emphasis on service of process while a defendant is physically present and greater emphasis on factors that fit comfortably within the minimum contacts concept in American jurisprudence. ${ }^{56}$ Thus, a defendant always may be sued where he or she lives, and nonresident defendants also may be sued when they have intentionally engaged in transactions with someone in the forum state..$^{57}$ Beyond that, some European jurisdictions, such as France and Scotland, assert what is known as "exorbitant bases of jurisdiction." 58 One exorbitant basis permits courts in the plaintiff's place of residence to hear suit against nonresident defendants, at least when the claim has some relationship to the jurisdiction. Another allows what Americans would call quasi in rem jurisdiction. A third allows jurisdiction over anyone served with process while temporarily present within the forum-so-called "tag" jurisdiction. ${ }^{59}$

The Constitution permits in rem jurisdiction when a civil defendant has property located in the forum state and the dispute relates to the property. Quasi in rem jurisdiction-when a defendant has property in the forum state but the dispute is unrelated to the property-probably is permissible only when the plaintiff can show exigent circumstances, such as a practical inability to effect

Burger King Corp. v. Rudzewicz, 471 U.S. 462, 477 (1985) (citing World-Wide Volkswagen Corp. v. Woodson, 444 U.S. 286, 292 (1980), and identifying factors); see also Madara v. Hall, 916 F.2d 1510, 1517 (11th Cir. 1990) (citing Burger King, 471 U.S. at 477 , and listing factors).

54. See World-Wide Volkswagen, 444 U.S. at 295-96 (setting forth foreseeability principle); Asahi, 480 U.S. at 109-12 (same).

55. See Burger King, 471 U.S. at $479-80$.

56. See generally Friedreich Juenger, Judicial Jurisdiction in the United States and in the European Communities: A Comparison, $82 \mathrm{MrCH}$. L. Rev. 1195 (1984).

57. The Brussels Convention binds signatory states-the members of the European Union-to rules for jurisdiction and enforcement roughly corresponding to the rules under International Shoe and its progeny. See A.E. ANTON \& PAUL R. Beaumont, ANTon \& Beaumont's Civil Jurisdiction in Scotland ch. 5, at 90-124 (1995) (explaining bases of jurisdiction under Convention).

58. Id. $\S 1.10$, at 6-7 (explaining exorbitant bases of jurisdiction with examples).

59. Id. 
personal service on the defendant. ${ }^{60}$ While it may be tempting to suppose that quasi in rem or in rem jurisdiction could be used expansively to obtain meaningful relief by a wrongdoer by computer, Internet technologies decrease, rather than increase, the likelihood of valuable assets being located in the jurisdiction of the plaintiff. Even if an argument could be sustained that an Internet server used to disseminate the harmful information is vicariously "present" in the forum state, turning the property into money requires the practical exercise of dominion and control over something that can be sold, and vicarious presence is not sufficient. If the server is a SPARC station and is located in Luxembourg, the plaintiff and judgment creditor will get money only if the SPARC station can be sold and that requires obtaining control over it in Luxembourg. Vicarious presence of that computer in Virginia because it is easily accessible from Virginia is not enough to permit it to be sold in Virginia.

Longarm jurisdiction in civil cases knows no real counterpart in criminal personal jurisdiction because of the rule that persons may not be tried in absentia. Thus, while it is tempting to compare the service of process in another jurisdiction with extralegal acquisition of custody, the resources required to do the latter are substantially greater than those required for the former, and the affront to the sovereignty of the place of service or acquisition of custody is much greater for the latter. On the other hand, the effect of the apparent difference is narrowed by similarities in the problems of judgment enforcement. ${ }^{61}$

\section{B. Obtaining Personal Jurisdiction over Publications ${ }^{62}$}

A number of cases apply the minimum contacts and fair play and substantial justice factors to print publications. These cases are helpful in applying personal jurisdiction doctrine to the GII because print publications, like electronic ones, spread out and come in contact with a multiplicity of jurisdictions, based on conduct that is concentrated at the place of the author or publisher. A publication usually satisfies the minimum contacts analysis if it has a sub-

60. See Shaffer v. Heitner, 433 U.S. 186, 208-12 (1977) (noting that presence of property in state "does not automatically confer jurisdiction over the owner's interest in that property").

61. For a further discussion of enforcement of judgments, see Part VI, infra notes 273-355 and accompanying text.

62. The research and initial drafting of this section was done by Andrew J. Vella, Villanova Law School Class of 1996, law clerk to the author. 
stantial circulation in the jurisdiction ${ }^{63}$ or if the defendant publisher intended to cause injury in the jurisdiction. ${ }^{64}$

Similar minimum contacts analysis applies when the defendant makes an allegedly tortious statement which is later published by another, although the maker of the statement may have less responsibility for where circulation occurs. In Madara v. Hall, ${ }^{65}$ the plaintiff, a California resident, brought suit in a Florida district court against the defendant for an allegedly libelous statement made by the defendant in California during a telephone interview with a magazine reporter. ${ }^{66}$ The statements were later published in a magazine which was circulated in Florida. ${ }^{67}$ The United States Court of Appeals for the Eleventh Circuit applied the traditional minimum contacts analysis in considering whether the defendant had sufficient contacts with Florida to warrant personal jurisdiction over him. ${ }^{68}$

The court determined that the defendant was "not subject to personal jurisdiction in Florida." 69 First, the forum was not convenient to either of the parties. ${ }^{70}$ Second, Florida had little interest in adjudicating the dispute because neither party resided in the state. ${ }^{71}$ Finally, "neither the interstate judicial system's interest in obtaining the most efficient resolution of controversies nor the interest of the states in furthering fundamental social policies would be served by subjecting Hall to the jurisdiction of Florida courts."72

In Ticketmaster-New York, Inc. v. Alioto, ${ }^{73}$ the plaintiff brought a defamation action in the United States District Court for the Dis-

63. See Keeton v. Hustler Magazine, Inc., 465 U.S. 770, 781 (1984) (holding that defendant "continuously and deliberately exploited the New Hampshire market" by circulating its magazine in that jurisdiction).

64. See Calder v. Jones, 465 U.S. 783, 789 (1984) (holding that California's exercise of jurisdiction was proper over Florida defendants in libel action arising out of article written and edited by defendants in Florida which was intended to cause injury to plaintiff in California).

65. 916 F.2d 1510 (11th Cir. 1990).

66. Id. at 1513.

67. Id.

68. Id. at 1514-17.

69. Id. at 1519 (distinguishing Keeton and holding no personal jurisdiction present). In distinguishing Keeton, the court stated that "[s]imply giving an interview to a reporter is not enough to cause Hall to anticipate being haled into court in Florida. Hall was not the magazine's publisher and did not control its circulation and distribution; thus, he is in a qualitatively different position than the defendant in Keeton." Id.

70. Id.

71. $I d$.

72. Id.

73. 26 F.3d 201 (1st Cir. 1994). 
trict of Massachusetts against the defendant, a California resident, for statements he made during a telephone interview which were later published in a Massachusetts newspaper. ${ }^{74}$ The court held that two factors determine purposeful availment: foreseeability and voluntariness. ${ }^{75}$ It stated that if "the source of an allegedly defamatory remark did not initiate the pivotal contact, and the in-forum injury is not reasonably foreseeable, jurisdiction may not be asserted over the source based on the comment." ${ }^{\prime 6}$ The defendant did not make the initial contact, but the in-forum injury was foreseeable. ${ }^{77}$ But then the Court of Appeals "evaluate[d] the fairness of asserting jurisdiction in the totality of the circumstances"78 and found that it would be fundamentally unfair to assert personal jurisdiction over the defendant, ${ }^{79}$ in part because of the burden on the defendant of defending in Massachusetts. Requiring "a California resident to appear in a Massachusetts court is onerous in terms of distance, and there are no mitigating factors to cushion that burdensomeness here." ${ }^{80}$ It would not be fair "on the strength of a single remark uttered in the course of a single unsolicited telephone call from a Massachusetts-based journalist, to compel a California resident to defend a tort suit in a court 3000 miles away." 81

The touchstones of personal jurisdiction analysis drawn from print publication cases are appropriate for GII cases. An electronic publisher should be subject to personal jurisdiction in any place to which the electronic publisher intentionally sends its publication. Thus, subscription-based commercial systems like CompuServe or America Online should be subject to personal jurisdiction in places

74. Id. at 203-04. The court framed the issue by asking "whether an individual who merely answers a telephone call, but, having done so, knowingly directs his comments into the forum state, ... purposefully avail[s] himself of the privilege of conducting activities in the state." Id. at 207.

75. Id.

76. Id. at 208.

77. Id.

78. Id. at 209.

79. Id. at 210. But cf. Dion v. Kiev, 566 F. Supp. 1387 (E.D. Pa. 1983). In Dion, the defendant was contacted by a Philadelphia Inquirer reporter and gave statements to that reporter during a telephone interview. $I d$. at 1388-89. The court asserted personal jurisdiction over the defendant, reasoning that:

[T] he defendant was fully aware that the reporter was from the Philadelphia Inquirer and that it was a major metropolitan newspaper in Pennsylvania with a major distribution in the Philadelphia area. It was readily foreseeable to [the defendant] that his statement about plaintiff could be published in the Philadelphia area and result in harm to plaintiff.

Id. at 1390.

80. Alioto, 26 F.3d at 210.

81. Id. at 212. 
where significant numbers of their subscribers reside. The residence of subscribers is known to these services; they derive revenue from those subscriptions, and there is little reason to distinguish between the electronic subscriber and the print subscriber. If an electronic publisher (including an individual poster) publishes a statement intended to injure someone, the publisher should be subject to personal jurisdiction in the place where the injured party is located, under the precedent represented by Calder $v$. Jones, ${ }^{82}$ although the Gestalt factors might be brought into play and lead to a different result as in Madara.

There are many conceivable GII cases in which publication does not support the exercise of personal jurisdiction so strongly. For example, one might post a message to a list. The list causes dissemination to all those subscribed to the list. But the poster usually has no knowledge of the extent of the list and thus the dissemination of this posting to a particular person is usually neither purposeful nor foreseeable, unless other facts indicate specific knowledge of a particular recipient of messages posted to that list. Absent such special facts, the exercise of personal jurisdiction is not appropriate merely based on the dissemination of messages through the list. An even weaker case for the assertion of personal jurisdiction arises from placement of material on servers connected to the Internet or Internet-like open architectures. Then, the act resulting in the receipt of the message in a particular place is the act, not of the publisher, but of the retriever. Publication in these circumstances should not subject the publisher to personal jurisdiction in places where the information is retrieved, under the rationale of Hansen v. Denckla. ${ }^{83}$

The Internet, and especially its World Wide Web application, creates a publishing infrastructure in which responsibility for "sending" information depends on the particular technological configuration. Many of them, unlike print publishing, rely on the consumer to come to the publisher and to trigger the transmission to that particular consumer. An exchange the author had online through one of the Counsel Connect (CC) electronic seminars with another participant fairly frames the characterization issue. The other CC participant said that the system operator in cases like the one shown in Figure 1 below is like someone who leaves a number of objects

82. 465 U.S. 783 (1984). For a further discussion of Calder, see supra note 64 and accompanying text.

83. 357 U.S. 235 (1958). Hansen held that the unilateral acts of others cannot subject a defendant to personal jurisdiction based solely on minimum contacts. Id. at $250-54$. 
on the floor. The requester is like someone who uses a vacuum cleaner to pick the objects up. The vacuum cleaner bag is like the

Figure 1

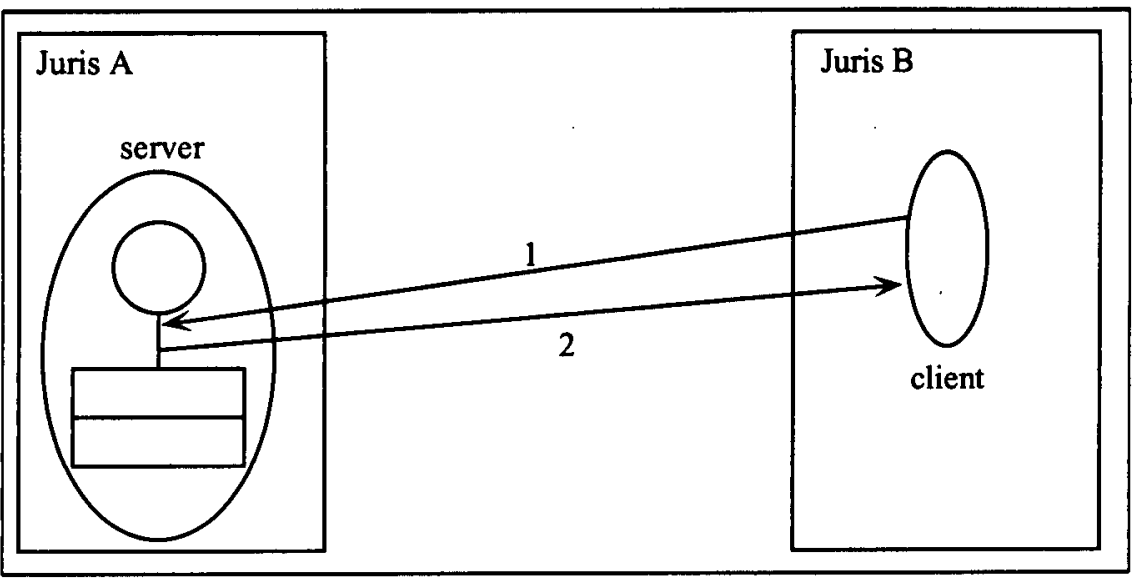

jurisdiction in which the effect of the information is felt. No sensible person, he said, would assert that the person leaving the objects on the floor had placed them in the bag of the vacuum cleaner.

The author preferred a different metaphor, comparing the electronic service to a vending machine in which the operator had placed different types of items in particular compartments for customer selection. The electronic customer is then like the vending machine customer, who selects a particular type of item, inserts money if necessary, and pulls the handle or pushes a button causing that type of item to be delivered. The vending machine comparison lends support to the fairness of treating the operator as a seller of that particular item, subject to regulation by whomever has jurisdiction over the vending machine compartments. That is so even though the vending machine operator was in some sense passive, and the actual delivery of the item occurred only when the customer acted to cause it to be delivered. Of course both metaphors involve conscious placement of items in a place from which they will be retrieved. Both metaphors recognize that determining who causes the content in question to enter a particular jurisdiction seeking to regulate the content is important in determining 
whether that jurisdiction may regulate it. ${ }^{84}$

The typical bulletin board/electronic publisher concept is illustrated in Figure 1. The server not only provides pointers and other finding and retrieval value, represented by the rectangles below the circle; it also publishes content, represented by the circle. The client has dealings only with the server, which looks like a conventional publisher, except that the publisher does not send anything (or even make a copy) until the client requests it.

FIGURE 2

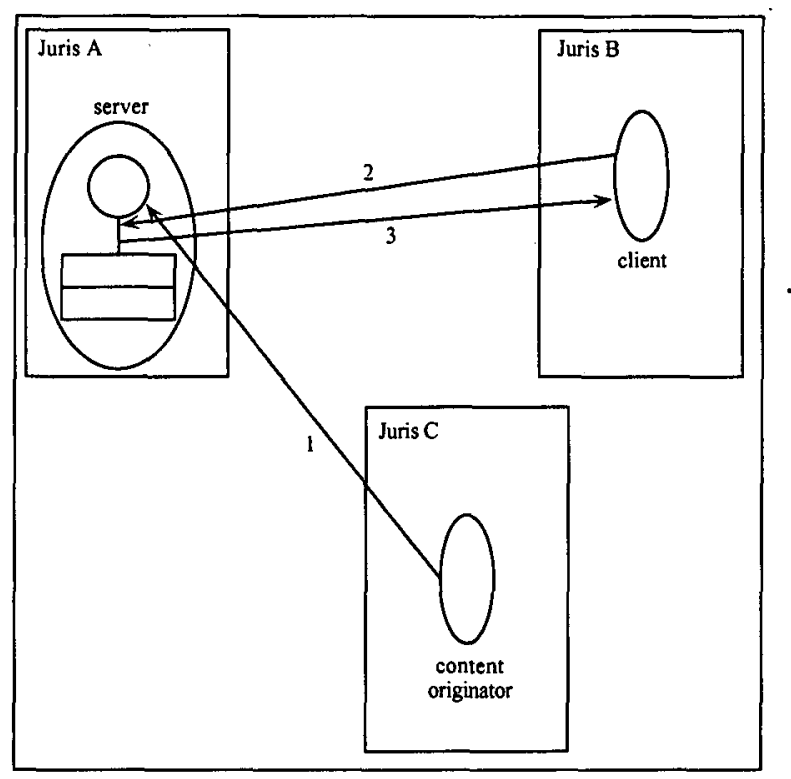

In Figure 2, the operator simply sets aside an electronic space within which others can exchange material. The content originator posts a file to the server, from whence it is retrieved by the client. In that situation, the operator may have no knowledge of what items are being offered and retrieved, and thus it is more difficult than in Figure 1 to conclude that the operator is responsible for the contact between the item and Jurisdiction $B$. Not only was the operator not the initiator of the transmission to Jurisdiction $B$, but it may have lacked knowledge that the particular item was available for transmission to Jurisdiction $B$. Still, the the server has control over its facilities and could have blocked the content originator from posting material there.

84. See Restatement (Third) of Foreign Relations Law $\$ 401$ (1987) (listing categories of jurisdiction); id. $\$ \S 402-03$ (stating bases of, and limitations on, jurisdiction to prescribe). 
FIGURE 3

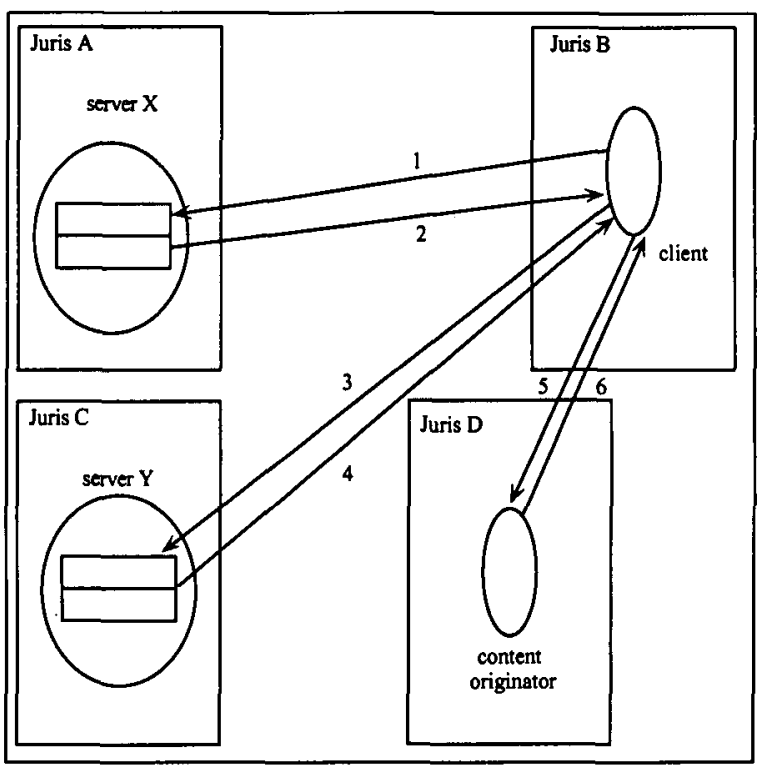

The typical Web server is in yet a different situation, as shown in Figure 3. Web server $X$ never has possession of the content. It points to server $Y$, which in turn points to the content on the server of the content originator. Transactions 1-4 with servers $X$ and $Y$ are requests for and transmissions of pointers only. The eventual request for and retrieval of the content transpires entirely between the client and the content originator in transactions 5 and 6 . The Web server that simply points to other (content) servers is rather like one who gives directions to the dirty movie theater or to the drug dealer. While the supplier of the pointers can be said to be involved in the distribution chain, he or she never comes in contact with the accused material.

In the Web often the information is transmitted indirectly as a result of interactions between user/requesters and intermediaries who point to particular information objects-sometimes without the knowledge of the person making the information object available. Such an infrastructure is not only two-layered; in many cases a pointer points, not directly to the full information resource, but to another collection of pointers, which may point to still other collections of pointers and so on, as in Figure 3, collectively marking a trail to the complete resource. The computer programs involved assemble a trail from the three pointers and then retrieve the de- 
sired content from wherever it resides, directly into the computer of the requester, without the content having to traverse all the intermediary computers. Whether an intermediary points directly or indirectly to the desired resource is inherently an engineering decision driven by performance considerations. In many cases, the decision to maintain copies of a particular information resource is made entirely automatically without any human intervention. A clear example of this is in the caching of recently-retrieved resources within a World Wide Web browser such as Netscape.

Unless one is to accept a broad stream of commerce theory of personal jurisdiction, which was rejected in World-Wide Volkswagen ${ }^{85}$ and $A s a h i,{ }^{86}$ none of the publishers, save the one in Figure 1 above, are within the personal jurisdiction of courts in Jurisdiction $B$. Moreover, it is dubious whether the content originator in Figure 2 is within the jurisdiction of the courts of Jurisdiction $B$. While the originator-or his or her computerized agent-purposefully sent the information item into Jurisdiction $B$, the sending occurred instantaneously in response to the address supplied by the client, without any advance arrangement by the content originator. The only place that clearly has jurisdiction over the content originator is Jurisdiction $D$. Jurisdictions $A$ and $C$ have jurisdiction over the intermediaries $X$ and $Y$, but the victim may not have a cause of action against them. ${ }^{87}$

In Pres-Kap, Inc. v. System One, Direct Access, Inc., ${ }^{88}$ a split panel of the intermediate Florida court held that Florida courts lacked personal jurisdiction over a New York travel agent who contracted to use an airline reservations system with its main database located in Miami, Florida. ${ }^{89}$ The majority opinion expresses rhetorical concern over the implications of holding that the location of computer databases could determine personal jurisdiction over suits against

85. World-Wide Volkswagen Corp. v. Woodson, 444 U.S. 286 (1980).

86. Asahi Metal Indus. Co. v. Superior Court, 480 U.S. 102 (1987). A more limited stream of commerce theory is consistent with Asahi. An actor who places something into a "narrow" stream, going only to a few places, is subject to jurisdiction in the destinations of the stream.

87. Compare Cubby, Inc. v. CompuServe, Inc., 776 F. Supp. 135, 139-40 (S.D.N.Y. 1991) (imposing no intermediary liability based on lack of knowledge of defamatory item) with Stratton Oakmont, Inc. v. Prodigy Servs. Co., 1995 WL 323710 , at *4-5 (N.Y. Sup. Ct., May 24, 1995) (finding intermediary potentially liable as publisher for defamatory item because it undertook to screen items appearing through its service). See also Playboy Enters., Inc. v. Frena, 839 F. Supp. 1552, 1559 (M.D. Fla. 1993) (holding intermediary strictly liable for copyright-infringing item).

88. 636 So. 2d 1351 (Fla. Dist. Ct. App. 1994).

89. Id. at 1353. 
those who use them, but offers little analysis as to why personal jurisdiction should not have existed under Burger King. ${ }^{90}$ The dissent is more persuasive. ${ }^{91}$

Plus System, Inc. v. New England Network, Inc. ${ }^{92}$ provides more guidance than Pres-Kap. In Plus System, a Colorado-based ATM network sued its New England affiliate for refusing to implement a new royalty charge. ${ }^{93}$ In rejecting the challenge to personal jurisdiction, the district court found, among other things, that the defendant's regular use of the plaintiff's computer system located in Colorado was an availment of Colorado and its law. ${ }^{94}$ The defendant benefitted from the services provided by plaintiff's computer system, and it made no difference that the defendant's connection occurred indirectly through a service organization in Wisconsin..$^{95}$ There were, to be sure, other contacts, including a visit and tour of the Colorado computer facility by defendant's personnel, a contractual choice of law clause that pointed to Colorado and signature by the plaintiff, at least, of the contract in Colorado. ${ }^{96}$

\section{Venue}

Even when personal jurisdiction exists, venue may not be proper. ${ }^{97}$ Civil actions in federal court based on diversity jurisdiction may be brought in a judicial district where any defendant resides, where a substantial part of the events or omissions giving rise to the claim occurred, where a substantial part of the property that is the subject of the claim is situated or in "a judicial district in which the defendants are subject to personal jurisdiction at the time the action is commenced, if there is no district in which the action otherwise may be brought." 98 The rules for actions based on

90. Id. (citing Burger King Corp. v. Rudzewicz, 471 U.S. 462, 478 (1985)).

91. Compare id. at 1353 (expressing concern about Westlaw, Lexis and other databases) with id. at 1354 (Barkdull, J., dissenting) (arguing that executing contracts and making rental payments in Florida put appellant on notice of possible suit in Florida).

92. 804 F. Supp. 111 (D. Colo. 1992).

93. Id. at 115 .

94. Id. at 118 .

95. Id. at 119 .

96. Id. at 118 .

97. Venue rules have become more important in civil cases as limitations on the exercise of judicial power as personal jurisdiction-based limitations have diminished. See Stein, supra note 15, at 803 (noting expansion of personal jurisdiction). Because personal jurisdiction in criminal cases has remained relatively unchanged, the independent role of venue doctrine is less important in criminal cases.

98. 28 U.S.C. $§ 1391$ (a) (1994) (establishing venue rules for jurisdiction based on diversity of citizenship). 
federal question jurisdiction are the same, except that the catch-all allows litigation in "a judicial district in which any defendant may be found," as opposed to one in which the defendant is "subject to personal jurisdiction." 99 These venue rules are typical; most state rules are similar. These basic venue rules would permit litigation in any forum in which personal jurisdiction exists, because the transactional link necessary to support personal jurisdiction, a fortiorari, would support venue.

Reuber $v$. United States, ${ }^{100}$ a case involving electronic conduct, provides some interesting guidance on venue under a specialized statute. Reuber filed a claim under the Federal Tort Claims Act (FTCA), which authorizes venue only in the judicial district where the plaintiff resided or "wherein the act or omission complained of occurred."101 The language limiting venue is a more restrictive version of the language in the general federal venue statute. ${ }^{102}$ The plaintiff filed one suit in the United States District Court for the District of Columbia, and another, against a co-defendant, in Maryland state court, which was removed to the United States District Court for the District of Maryland. The District of Columbia action was transferred to Maryland, ${ }^{103}$ and the United States claimed improper venue in the action against it. The court of appeals distinguished a case involving an FTCA suit over an air traffic controller transmission from Utah to a pilot flying over Montana causing that pilot to crash. ${ }^{104}$ The court found that the radio transmission was directed specifically to the pilot in Montana and thus the situs of the act in that case could reasonably be perceived as including the place where the tortious radio transmission was targeted and where the foreseeable harm would occur. ${ }^{105}$ But in Reuber's case, the allegedly tortious conduct involved disclosure and dissemination of a letter critical of him, and the court of appeals found that even though some communication occurred in Maryland, the tortious

99. Compare 28 U.S.C. $\$ 1391$ (b) (1994) (establishing federal question jurisdiction) with id. $\S 1391$ (a) (1994) (establishing diversity of citizenship jurisdiction).

100. 750 F.2d 1039 (D.C. Cir. 1984).

101. 28 U.S.C. $\$ 1402$ (b) (1994) (establishing venue rules for tort claims against United States).

102. Compare 28 U.S.C. $\$ 1402$ (b) (1988) (establishing venue for tort claims against United States) with id. $\S 1391$ (a), (b) (establishing venue for diversity jurisdiction and federal question jurisdiction cases).

103. Reuber, 750 F.2d at 1046.

104. Id. at 1047 (analyzing and distinguishing Forest v. United States, 539 F. Supp. 171 (D. Mont. 1982)).

105. Id. 
act was complete upon the release, which occurred in the District of Columbia.

Forum non conveniens is a more significant practical limitation on venue than express limitations in statutes authorizing venue. ${ }^{106}$ Forum non conveniens is a doctrine that permits the dismissal of cases on the grounds that the venue is inconvenient. It depends on a showing that venue lies in another, more convenient place. ${ }^{107}$ Forum non conveniens dismissals are less common in fed-

106. Forum non conveniens is a relatively recent judicial doctrine, dating only from roughly the middle of this century. See Stein, supra note 15, at 796. Pressure is growing to unify forum non conveniens doctrines with the closely related fair play and substantial justice analysis of personal jurisdiction and to rationalize application of venue concepts to foreign plaintiffs. See generally Silberman, supra note 19, at 501 (proposing federal legislation to govern jurisdiction over alien defendants and access to U.S. courts by foreign plaintiffs). Professor Allan Stein would unify the doctrines of judicial authority to focus on identifying "the court with the paramount interest in a controversy," so that it may adjudicate the case. Stein, supra note 15 , at 842 . This criterion protects against choice of forum that unduly burdens the forum state's courts and deprives a more appropriate forum of its regulatory prerogatives. He would also de-emphasize access to evidence, based in part on improvements in technology and transportation. Id. He would incorporate into personal jurisdiction doctrine the relationship between the court and the controversy. $I d$. at 843 . If "the forum appears to have no legitimate regulatory stake in the controversy, then we should say that the court does not have jurisdiction to resolve the dispute or that the court does not have jurisdiction if the alternative forum does." Id. Finally, he would eliminate the deference accorded to plaintiff's choice of forum. Id. at 844. Although I am impressed by Professor Stein's careful analysis and his argument in favor of incorporating many of the forum non conveniens factors into more formal notions of jurisdiction, $I$ am unpersuaded by his seeming preference for the identification of a unique forum for adjudication. The needs of litigants and governments may be perfectly well served by jurisdictional doctrines that permit adjudication in several fora of equal competence and convenience.

Professor Stanley E. Cox urges that jurisdictional doctrines be simplified by adoption of his thesis "that courts exist only to interpret, create and apply their own government's laws." Stanley E. Cox, Razing Conflicts Facades to Build Better Jurisdiction Theory: The Foundation-There Is No Law but Forum Law, 28 VAL. U. L. REV. 1, 3 \& n.1 (1993). From this thesis, he derives three "subtruths:" a court has jurisdiction only when it can apply its own substantive law; a court with jurisdiction must always apply its own law rather than exploring choice of law rules; and a court cannot create shared sovereignty between governments unless the interested sovereigns have unequivocally negotiated for shared sovereignty. Id. at 4-6 \& nn.4-5.

107. Compare Piper Aircraft Co. v. Reyno, 454 U.S. 235, 238 (1981) (approving dismissal of case brought by Scottish plaintiff as result of air crash in Scotland) with Dow Chem. Co. v. Castro Alfaro, 786 S.W.2d 674 (Tex. 1990) (reversing dismissal of suit by foreign employees of American company), cert. denied, 498 U.S. 1024 (1991), and Picketts v. International Playtex, Inc., 576 A.2d 518, 529 (Conn. 1990) (reversing dismissal of suit by Canadian plaintiffs on forum non conveniens grounds) (videotape depositions make it more difficult for defendant to satisfy burden of showing inconvenience). But see Stangvik v. Shiley, Inc., 819 P.2d 14, 16 (Cal. 1991) (affirming forum non conveniens dismissal and adopting rationale of Piper); Myers v. Boeing Co., 794 P.2d 1272, 1274 (Wash. 1990) (affirming dismissal of damage claims by foreign plane crash victims). 
eral than in state courts because transfer to a more convenient forum is straightforward. ${ }^{108}$ According to the United States Code, "[f] or the convenience of parties and witnesses, in the interest of justice, a district court may transfer any civil action to any other district or division where it might have been brought." 109 In addition, the multidistrict litigation procedure allows cases involving one or more common questions of fact pending in different districts to be consolidated for pretrial proceedings based on an application to the judicial panel on multidistrict litigation. ${ }^{110}$ Forum non conveniens may exert considerable influence on the choice of forum for litigating GII disputes. In Figure 3 above, for example, Jurisdiction $B$ would rarely qualify as a convenient forum, compared with Jurisdictions $A, C$ or $D$.

In Creative Technology, Ltd. v. Aztech System Pte. Ltd.,111 the Ninth Circuit applied an analytical framework that requires the person moving for dismissal to demonstrate the existence of an adequate alternative forum and a balance of private and public factors militating in favor of dismissal. ${ }^{112}$ The private factors include: "(1) relative ease of access to sources of proof; (2) the availability of compulsory process for attendance of unwilling witnesses, and cost of obtaining attendance of willing witnesses; (3) possibility of viewing subject premises; [and] (4) all other factors that render trial of case expeditious and inexpensive."113 In the case before it, the court thought the first factor favored dismissal because all of the records and most of the witnesses were located in Singapore. The fourth factor favored dismissal because a parallel lawsuit in the Singapore courts was more advanced than the U.S. action. The third factor was neutral, while the second factor militated against dismissal because most of the expert witnesses resided in California. ${ }^{114}$

108. See 28 U.S.C. $\$ 1404$ (1994) (allowing district court to transfer any civil action for convenience).

109. Id. $\$ 1404$ (a) (establishing change of venue rules).

110. Id. $\$ 1407$ (establishing procedural rules for coordination or consolidation of pretrial proceeding in multidistrict litigation).

111. 61 F.3d 696 (9th Cir. 1995) (affirming dismissal on forum non conveniens grounds of copyright infringement suit by one Singapore corporation against another). For a further discussion of Creative Technology, see Lynn Carino, Note, Creative Technology, Ltd. v. Aztech System Pte. Ltd.: The Ninth Circuit Sends a United States Copyright Infringement Case to Singapore on a Motion of Forum Non Conveniens, 41 VIIL. L. REV. 325 (1996).

112. Creative Technology, 61 F.3d at 699 (citing Contact Lumber Co. v. P.T. Moges Shipping Co., 918 F.2d 1446, 1449 (9th Cir. 1990) (citing Gulf Oil Corp. v. Gilbert, 330 U.S. 501, 508-09 (1947), cert. denied, 486 U.S. 1054 (1988))).

113. Id. at 703 (citing Zipfel v. Halliburton Co., 832 F.2d 1477, 1485 (9th Cir. 1987) (citing Gulf Oil, 330 U.S. at 508).

114. Id. 
The public interest factors identified in the court's opinion include: "(1) administrative difficulties flowing from court congestion; (2) imposition of jury duty on the people of a community that has no relation to the litigation; (3) local interest in having localized controversies decided at home; (4) the interest in having a diversity case tried in a forum familiar with the law that governs the action; [and] (5) the avoidance of unnecessary problems in conflicts of law."115 The court of appeals agreed with the district court that the first and fourth factors were neutral in effect, while the second factor favored dismissal because both plaintiff and defendant were residents of Singapore and the wrongful acts of copyright infringement occurred there. ${ }^{116}$ Circuit Judge Ferguson dissented, noting that he was "astounded when I read that it is not convenient to try an American copyright case in an American court for copyright infringement that takes place solely in America ... [and] by a decision that the convenient place to hold the trial is in Singapore, particularly when the majority have not the slightest idea that a court in that nation would even recognize an American copyright." 117

Greater certainty with respect to the place of litigation can be obtained through the use of forum-selection clauses, which are an important determinant of venue. Historically, such clauses were not favored, but in a series of cases beginning with The Bremen $v$. Zapata Off-Shore Co., ${ }^{118}$ the Supreme Court has been increasingly hospitable to them. In Stewart Organization, Inc. v. RICOH Corp., 19 the Supreme Court held that federal law rather than state law governs the enforceability of a forum-selection clause in a contract within the diversity jurisdiction of a federal district court. ${ }^{120}$ Justices Kennedy and O'Connor wrote a concurring opinion explaining that enforcement of forum-selection clauses protects party expectations and furthers vital interests of the justice system, thus extending the rationale of The Bremen to federal courts sitting in 508)).

115. Id. at 703-04 (citing Zipfel, 832 F.2d at 1485 (citing Gulf Oil, 330 U.S. at

116. Id. at 704 .

117. Id. at 705 (Ferguson, J., dissenting).

118. 407 U.S. 1 (1972).

119. 487 U.S. 22 (1988).

120. Id. at $27-28$ (concluding that federal law, 28 U.S.C. $\$ 1404$ (a), governed under application of Erie doctrine). In Erie Railroad Co. v. Thomkins, 304 U.S. 64 (1938), the Supreme Court held that state law must be applied in diversity cases, unless a federal rule of procedure, statute or constitutional provision governs. Id. at 78; see also Hanna v. Plumer, 380 U.S. 460, 471 (1965) (holding that federal law must be applied when valid federal rule of civil procedure governs issue). 
diversity. ${ }^{121}$

In Carnival Cruise Lines, Inc. v. Shute, ${ }^{122}$ the Supreme Court made it more difficult to avoid forum-selection clauses even when they are contained in form contracts and not actually negotiated. ${ }^{123}$ The Court acknowledged that forum-selection clauses are subject to judicial scrutiny for fundamental fairness and suggested that they are unenforceable if there is evidence of their inclusion for the purpose of discouraging parties from pursuing legitimate claims by assigning litigation to a remote and alien forum, by proof that resisting parties lacked notice of the clause or evidence of fraud or other overreaching. ${ }^{124}$ Nevertheless, it extolled the virtues of such clauses as ways of dispelling confusion about where suits for breach of contract might be brought and defended "sparing litigants the time and expense of pretrial motions to determine the correct forum and conserving judicial resources that otherwise would be devoted to deciding those motions." 125 In addition, the facts of the case made the forum designated by the clause-Florida-entirely appropriate and did not support the court of appeals's conclusion of inconvenience to the consumer. ${ }^{126}$ Although Carnival Cruise Lines was an admiralty case, there is no suggestion in the opinion that diversity or federal question cases would be treated any differently.

The presumption in favor of enforcing forum-selection clauses regularly is extended to clauses in international contracts that provide for litigation in the fora of other countries. ${ }^{127}$ Further, the forum-selection clause cases have important implications for electronic commerce. They permit reduction of the uncertainty with respect to the place of litigation, and they also reduce uncertainty

121. Stewart, 487 U.S. at 33 (Kennedy, J., concurring) (filing separate opinion in support of forum-selection clauses).

122. 499 U.S. 585 (1991).

123. Id. at 593 (noting that contract was "purely routine and doubtless nearly identical to every commercial passage contract issued by petitioner and most other cruise lines"). "Common sense dictates that a ticket of this kind will be a form contract the terms of which are not subject to negotiation, and that an individual purchasing the ticket will not have bargaining parity with the cruise line." Id.

124. Id. at 595 .

125. Id. at 594 .

126. Id. at 594-95 (finding fairness because chosen forum, Florida, was cruise line's principal place of business and location of many of its departure and arrival ports).

127. See Bonny v. Society of Lloyd's, 3 F.3d 156, 160-61 (7th Cir. 1993) (rejecting arguments that clause requiring litigation in English courts imposed sufficient financial hardship to justify not enforcing it and concluding that English remedies adequately would vindicate plaintiff's substantive rights under securities laws), cert. denied, 510 U.S. 1113 (1994). 
about the methods of binding the user of an electronic service to a forum-selection clause. Forum-selection clauses not only resolve venue issues; they also resolve personal jurisdiction issues because a valid clause constitutes consent to personal jurisdiction in the forum selected. The Carmival Cruise Lines case reduces the likelihood that a participant in electronic commerce could avoid a forum-selection clause on the grounds that there was no negotiation over it. It should be enough to show that the resisting party had notice of the clause, and that the forum selected by the clause was reasonable in light of the nature of the contract.

\section{Service of Process and Attachment}

Service of process performs two functions in Anglo-American civil procedure: it represents assertion of judicial power of the forum state over the person of the defendant, and it is the formal means of providing notice to the defendant so that he or she may defend the lawsuit. ${ }^{128}$ Sections $\mathrm{A}$ through $\mathrm{C}$ above considered the power dimension of personal jurisdiction. This section considers the notice requirement of procedural due process in the civil litigation context. Service of process is a more important concept for civil procedure than criminal procedure because of the nearly universal prohibition in criminal justice systems against trials in absentia - the analog of a civil default judgment. ${ }^{129}$

In early Anglo-American procedure, a defendant subjected to personal jurisdiction was entitled to pre-seizure or pre-arrest notice except for claims involving breach of the peace or malice, in which case personal jurisdiction could be asserted by arresting the defendant under a writ of capias ad respondendum. Even when no breach of the peace or malice was involved, capias would issue if the defendant did not respond to the initial notice. Real claims-those involving what later came to be known as in rem jurisdiction-always could be commenced simply by attaching or otherwise levying on the property itself, regardless of whether separate notice was given to the person entitled to possession. Now, constitutional due process entitlements prohibit significant deprivation of liberty or property interests until notice is given. Thus, capias and commencement

128. See Mullane v. Central Hanover Bank \& Trust Co., 339 U.S. 306, 313-14 (1950) (distinguishing between service of process as means of exercising power and service of process as constitutionally sufficient means of giving notice).

129. In some minor criminal cases, a defendant is served with a summons rather than being arrested, but the penalty for not showing up is issuance of an arrest warrant, not a default conviction. See, e.g., PA. R. CRIM. P. $\S 102$ (West 1989) (using summons or warrant of arrest in criminal cases). 
of an action by attachment are reserved for exigent circumstances, such as those which involve a risk that the defendant will abscond or dispose of property before notice can be given. ${ }^{130}$

The Supreme Court has noted that "[p]ersonal service of written notice within the jurisdiction is the classic form of notice always adequate in any type of proceeding." 131 Other forms of notice may be constitutionally adequate when reasonably calculated under the circumstances to give actual notice. ${ }^{132}$ Of course, constitutional adequacy is not enough; the method of notice also must be authorized by some affirmative source of law representing the service of process rules of the forum. Additionally, service of process must occur within the time limits set by civil procedural rules, although extensions can be granted by the court. ${ }^{133}$

The growing use of digital information technologies introduces the possibility of electronic service of process, including telex, fax and e-mail, ${ }^{134}$ although these methods of service are not yet countenanced widely. ${ }^{135}$ Despite the practical feasibility and attractiveness of electronic service of process, authorization for electronic service is thin. On occasion, this form of service has been authorized in particular cases. ${ }^{136}$ Some commentators have urged

130. See Connecticut v. Doehr, 501 U.S. 1, 12-13 (1991) (invalidating lien on real estate imposed based on five-sentence affidavit; risk of erroneous deprivation of property interest too great); North Ga. Finishing, Inc. v. Di-Chem, Inc., 419 U.S. 601,608 (1975) (invalidating prejudgment garnishment under Fuentes); Fuentes v. Shevin, 407 U.S. 67, 96-97 (1972) (holding prejudgment attachment unconstitutional in absence of exigent circumstances and safeguards for property interests of person attached); Vermont Nat'l Bank v. Taylor, 445 A.2d 1122, 1124 (N.H. 1982) (quashing ex parte capias procedure used to initiate civil contempt proceeding).

131. Mullane, 339 U.S. at 313.

132. Id. at 313-14; see also Greene v. Lindsey, 456 U.S. 444, 444 (1982) (invalidating service of process by posting notice on door of low-income housing project).

133. See Petrucelli v. Bohringer \& Ratzinger GmbH, 46 F.3d 1298, 1305 (3d Cir. 1995). The court remanded the denial of an extension of time to serve process and the dismissal of complaint against the products liability defendant. Id. at 1311. The court also held that revised Rule $4(\mathrm{~m})$ mandates an abuse-of-discretion standard of review; here, the plaintiff made inexcusable errors by relying on the verbal assurance of an unknown person in the Secretary of State's Office, failing to inquire when notice of acknowledgment was not returned, claiming that mailing to Texas would be fruitless, and failing to inquire whether the corporation was in good standing with the Secretary of State's Office. Id. at 1306-07.

134. In addition, there is the conceptual possibility that service by publication might be accomplished by electronic publication in an appropriately public forum.

135. For example, changes to Federal Rule of Civil Procedure 4 were discussed in 1995 among the members of the Federal Rules Advisory Committee, but none were officially proposed.

136. See, e.g., New Eng. Merchants Nat'l Bank v. Iran Power Generation \& Transmission Co., 495 F. Supp. 73, 81 (S.D.N.Y. 1980) (authorizing service on Ira- 
authorization of service by facsimile, ${ }^{137}$ but most jurisdictions only authorize the use of facsimile or service of process after the initial service of summons and complaint. ${ }^{138}$ Some older state rules authorize telegraphic service, ${ }^{139}$ but fax service has the advantage that fax machines automatically produce an acknowledgment thus providing a form of proof of service.

Although the federal rules authorize service of process pursuant to the law of the forum state or the law of the state in which service is effected, ${ }^{140}$ and by the law of foreign countries in which service is to be made or under international treaty, ${ }^{141}$ the explicit provisions of the federal rule provide only modest possibilities for electronic service. ${ }^{142}$ The appellate rules permit individual courts of appeals to permit papers to be filed "by facsimile or other electronic means." 143 Few state rules permit electronic service. The Federal Rules Advisory Committee, supported by courts in which electronic service experiments were conducted, has dicussed amending the Federal Rules of Civil and Appellate Procedure to permit electronic service. ${ }^{144}$

Service of process is not the only way to commence an action against one within the personal jurisdiction of the court if a foreign defendant has minimum contacts with the foreign state. ${ }^{145}$ An action may be commenced by attaching property within the jurisdic-

nian defendants in Farsi and English by telex, followed by personal service on counsel and copies by mail, under FED. R. CIV. P. 4(i) (1) (E) as it then existed).

137. See, e.g., David A. Sokasits, Note, The Long Arm of the Fax: Service of Process Using Fax Machines, 16 Rutgers Computer \& TECH. L.J. 531, 539-43 (1990) (promoting use of fax machine for serving initial process of summons and complaint).

138. See id. at 547-49 (reviewing New York and Oregon rules).

139. Id. at 549 (citing IDAHo R. Crv. P. 4(c) (3); MONT. CoDE ANN. § 25-3-501; UTAH R. Civ. P. 4(1)).

140. FED. R. Crv. P. 4(e)(1) (providing rules for service upon individuals within judicial district of United States).

141. Id. 4(f) (authorizing service of process in foreign country pursuant to any convention on service abroad of judicial and extra judicial documents); see also id. $4 \mathrm{cmt}$. (1993 amendment) (explaining intent and application of new subdivi$\operatorname{sion}(\mathrm{f})$ ).

142. Id. 4(d)(2)(B) (failure-of-service provisions permitting notice of commencement of action and request that defendant waive service of summons, which can be "dispatched through first-class mail or other reliable means" (emphasis added)).

143. Fed. R. APP. P. 25(a) (Supp. 1995) (requiring, however, that local roles be consistent with standards established by Judicial Conference of United States).

144. The Federal Rules Advisory Committee has not officially proposed these amendments to allow electronic service of process; however, there have been discussions centered around this possibility.

145. Shaffer v. Heitner, 433 U.S. 186, 203 (1977) (requiring minimum contacts as prerequisite for commencing action by attachment). 
tion belonging to the defendant. ${ }^{146}$ This might seem a remote basis for commencing an action growing out of an electronic communication, until one realizes that the property belonging to the defendant might take the form of obligations under a service contract between the defendant and a service provider within the jurisdiction. ${ }^{147}$ When jurisdiction is obtained in this way, any judgment must be limited to the value of the property attached, although the rationale for this restriction is unclear, the suggestion that the nature of the jurisdiction effected by valid attachment is personal was made by Shaffer $v$. Heitner. ${ }^{148}$

Thus, in the unlikely event that a cyberspace defendant owned hardware that was physically located within the jurisdiction, and assuming that the defendant satisfied minimum contacts, a plaintiff could commence action by attaching the hardware. Far more likely is a situation in which the defendant has intangible rights to service provided by in-jurisdiction entities. For example, a foreign defendant might be a subscriber to America Online. In such a situation, the obligation by America Online to provide service could be subject to attachment or writ of garnishment. The problem, of course, is that the value of such a service contract is likely small. Of greater potential significance is the possibility that execution of the attachment could effectively cut off the defendant from some or all access in the forum jurisdiction. ${ }^{149}$

146. See Alessi v. Belanger, 644 So. 2d 778, 789 (La. Ct. App. 1994) (allowing commencement of action against out-of-state defendant by attaching wedding ring).

147. In Cameco Indus., Inc. v. Mayatrac, 789 F. Supp. 200 (D. Md. 1992), the district court held that an action could be commenced by a writ of garnishment against a bank account in state, but only if the defendant also had minimum contacts. Id. at 202-03. It held that the bank account by itself did not constitute minimum contacts under Shaffer. Id. at 202; see also Britton v. Howard Sav. Bank, 727 F.2d 315, 318-19 (3d Cir. 1984) (reversing district court and holding that action could be commenced by attaching certificates of deposit based on allegations that defendant was evading service of process; records showed ample contacts with state to satisfy due process).

148. 433 U.S. 186, 199 (1977).

149. See generally Friedt v. Moseanko, 498 N.W.2d 129, 133 (N.D. 1993) (ruling that money or property, other than earnings, held by third party is subject to garnishment). There is some room for argument, however, that services due would not be sufficiently liquidated to be subject to garnishment. See generally Harpster v. Reynolds, 524 P.2d 212, 215 (Kan. 1974) (holding no garnishment of wages from personal service contract when payments are made in advance of services performed); Sears, Roebuck \& Co. v. Romano, 482 A.2d 50, 53 (N.J. Super. Ct. Law Div. 1984) (holding that promise to advance funds not subject to garnishment). The rationale for the rule stated in Harpster apparently is that no payments are yet due; indeed, they are never due when a writ of garnishment is served on the employer. Rather, the employee is always indebted to the employer for the advances. Harpster, 524 P.2d at 216; see Haines v. Public Finance Corp., 218 N.E.2d 727, 729 


\section{E. Personal Jurisdiction in Criminal Cases}

Despite the infrequency of use of the term, at least some commentators have described jurisdiction over the person in criminal prosecutions as "personal jurisdiction." 150 Personal jurisdiction in criminal cases universally is based on physical presence, usually obtained through arrest. Rule 43 of the Federal Rules of Criminal Procedure requires the defendant's presence at the trial. ${ }^{151}$ Many countries, in addition to the United States, guarantee defendants the right to be tried in their presence. ${ }^{152}$ In addition, the International Covenant on Civil and Political Rights specifically prohibits trials in absentia. ${ }^{153}$ Commentators report that the defendant's presence is a requisite for a criminal trial under the national laws of many industrial countries. ${ }^{154}$ Once the trial commences, however, the continued presence of the defendant is not always required, 155

(Ohio Ct. App. 1966). (holding that intangible property subject to garnishment must be subject to appraisal; denying garnishment of invasion of privacy claim not yet sued on). But see Weir v. Galbraith, 376 P.2d 396, 401-02 (Ariz. 1962) (holding that installment contract payments due from purchaser to merchant were subject to garnishment).

150. Jacques Semmelman, The Doctrine of Specialty in the Federal Courts: Making Sense of United States v. Rauscher, 34 VA. J. INT'L L. 71, 72 \& n.3 (1993) (finding that doctrine of specialty "limits personal jurisdiction in the federal and state courts" to crime for which criminal defendant has been surrendered).

151. Fed. R. CRIM. P. 43(a). The rule states: "The defendant shall be present at the arraignment, at the time of the plea, at every stage of the trial including the impaneling of the jury and the return of the verdict, and at the imposition of sentence, except as otherwise provided by this rule." Id.

152. M. Cherif Bassiouni, Human Rights in the Context of Criminal Justice: Identifying International Procedural Protections and Equivalent Protections in National Constitutions, 3 Duke J. Comp. \& INT'L L. 235, 279 n.215 (1993) (listing over 20 countries that guarantee defendant's presence at own trial). Through a discussion with Professor Emmanuel Gross of the University of Haifa, I learned that Israel's rule requiring the defendant's presence is also similar to the United States.

153. Id. at $280 \mathrm{n} .218$ (citing International Covenant on Civil and Political Rights, G.A. Res. 2200 (XXI), 999 U.N.T.S. 171, U.N. GAOR, 21st Sess., Supp. No. 16, pt. III, art. 14(3)(d), at 54, U.N. Doc. A/6316 (1966)).

154. See generally Richard J. Terrill, World Criminal Justice Systems: A SURVEY (1984) (describing criminal justice systems throughout world). Specifically, Professor Terrill describes England, France, Sweden and Japan. Id. at 51-52, 150-51, 209-11, 278. But see Gallina v. Fraser, 177 F. Supp. 856, 865-66 (D. Conn. 1959) (ordering extradition to Italy of fugitive despite his argument that he was convicted in absentia), cert. denied, 364 U.S. 851 (1960).

155. Fed. R. CRIM. P. 43(b) states that a defendant's continued presence is not required:

The further progress of the trial to and including the return of the verdict shall not be prevented and the defendant shall be considered to have waived the right to be present whenever a defendant, initially present,

(1) is voluntarily absent after the trial has commenced (whether or not the defendant has been informed by the court of the obligation to remain during the trial), or

(2) after being warned by the court that disruptive conduct will 
as when the defendant flees during the trial ${ }^{156}$ or is removed from the courtroom due to disruptive conduct. ${ }^{157}$ Furthermore, under American law, the defendant's presence is not required in four other situations: 158 (1) if the defendant is a corporation, it may be represented solely by counsel; ${ }^{159}(2)$ if the offenses are punishable by a fine or imprisonment of not more than one year;'160 (3) "at a conference or argument upon a question of law"; ${ }^{161}$ and (4) for a reduction of sentence. ${ }^{162}$ Accordingly, exercising jurisdiction over international computer crimes requires obtaining custody of the individual defendant which can be obtained through the formal process of extradition or by extralegal means. ${ }^{163}$

\section{F. Pre-Trial Extradition}

International extradition is a means of obtaining criminal jurisdiction over a defendant not found within the territorial limits of the forum state. ${ }^{164}$ Extradition arose in the mid-nineteenth century Id.

cause the removal of the defendant from the courtroom, persists in conId.

duct which is such as to justify exclusion from the courtroom.

156. Fed. R. Crum. P. 43(b) (1) (allowing court to proceed if defendant is voluntarily absent); Bassiouni, supra note 152, at 279-80 (discussing exceptions to requirement of defendant's presence).

157. FED. R. CRIM. P. 43(b) (2) (allowing court to remove defendant after giving defendant warnings).

158. Federal Rule of Criminal Procedure 43(c) states:

A defendant need not be present in the following situations:

(1) A corporation may appear by counsel for all purposes.

(2) In prosecutions for offenses punishable by fine or by imprison-

ment for not more than one year or both, the court, with the written consent of the defendant, may permit arraignment, plea, trial, and imposition of sentence in the defendant's absence.

(3) At a conference or argument upon a question of law.

Id. $43(\mathrm{c})$.

(4) At a reduction of sentence hearing under Rule 35.

159. Id. 43(c)(1).

160. Id. 43(c) (2). The defendant must give the court written consent and the court may then proceed without the defendant's presence. Id.

161. Id. 43(c)(3).

162. Id. 43(c) (4).

163. Ethan A. Nadelmann, The Evolution of United States Involvement in the International Rendition of Fugitive Criminals, 25 N.Y.U. J. INT'L. L. \& PoL. 813, 813-14, 85760 (1993) (stating that options for U.S. law enforcement officials include requesting extradition, requesting informal methods such as deportation or forcing fugitive out of requested country, requesting that foreign government prosecute fugitive in its own courts, or obtaining custody by abduction or trickery).

164. See generally Marian Nash Leich, Contemporary Practice of the United States Relating to International Law, 76 AM. J. INT'L L. 154 (1982) (describing extradition process through State Department and diplomatic channels, and describing content of extradition treaties). 
in order to impose legal obligations on signatories to extradite fugitives from other signatories, thus limiting unfettered discretion to grant asylum to any fugitive. ${ }^{165}$ Reluctance to enter into extradition treaties, however, stemmed from a reluctance to extradite persons charged with political crimes in the requesting state (or to extradite victims of ethnic or religious persecution). Because of the difficulty in defining political crimes, the result was treaties drafted to require extradition only for enumerated crimes, reinforced by the doctrine of specialty, which prohibits prosecution in the requesting state for crimes other than those used as the basis for extradition. ${ }^{166}$

The United States has extradition treaties with 100 nations. ${ }^{167}$ Historically, they were limited to certain crimes, but more recently include any crime subject to the principle of dual criminality: one is not extraditable under the treaty unless the crime for which his extradition is requested violates the criminal laws of both the requesting state and the requested state. ${ }^{168}$ U.S. policy is to replace enumerated crimes and extradition treaties with the dual criminality principle, subject to a political offense exception. ${ }^{169}$

Procedurally, the designated authority of the requesting state makes an official request for the extradition of a particular person. The courts of the requested state, acting upon a formal document issued by the justice or foreign affairs ministry, issue an arrest warrant. Once the target is arrested, he or she is entitled to a judicial hearing in which two findings must be made before extradition can proceed: first, that the arrested person is the person named in the extradition warrant; and second, that there is probable cause to believe that the person named committed the crime identified.170

165. Nadelmann, supra note 163 , at $823-29$ (describing history of extradition treaties, beginning in Europe, explaining American resistance to multilateral treaties and emphasizing recent focus on drug offenses); Semmelman, supra note 150, at 80-81 (describing history of and bases for extradition treaties).

166. See Semmelman, supra note 150, at 80 (discussing origins of doctrine of specialty).

167. André M. Surena et al., Extraterritorial Application of Criminal Law, in American Society of International Law, Proceedings of the 85th Annual MeEting 383, 384 (1991).

168. Nadelmann, supra note 163 , at $829-31$ (explaining how dual criminality provision supplanted more and more cumbersome enumerated list of extraditable offenses).

169. Surena et al., supra note 167 , at 384 .

170. See Lobue v. Christopher, 893 F. Supp. 65, 65 (D.D.C. 1995) (invalidating U.S.-Canadian Extradition Treaty). In virtually all cases, a request for extradition for trial must be supported by sufficient evidence to establish probable cause at the preliminary hearing stage in the United States. In re Extradition of Garcia, $890 \mathrm{~F}$. Supp. 914, 922 (S.D. Cal. 1994) (determining that probable cause question is not whether evidence is sufficient to justify conviction, but only whether there is com- 
The process under international extradition statutes resembles interstate extradition within the United States. Virtually all states within the United States have adopted the Uniform Criminal Extradition Act ("Act"). ${ }^{171}$ Under the Act, the governor of one state has a duty to arrest and to deliver to the executive authority of any other state any person charged with a crime in the other state who is found in the first state. ${ }^{172}$ Demands for extradition must be in writing and allege that the accused was present in the demanding state at the time the alleged crime was committed and thereafter fled from the state. ${ }^{173}$ The writing requirement apparently has not been construed to include or exclude a computer message.

Once the demand has been made, "[i]f the Governor decides that the demand should be complied with, he shall sign a warrant of arrest ... directed to any peace officer or other person whom he may think fit to entrust with the execution thereof." 174 Although the governor has a nondiscretionary duty to honor an extradition request, apparently there are no means of compelling him or her to honor it. ${ }^{175}$ No person may be returned after an arrest on an extradition warrant without being afforded the opportunity to challenge the legality of the arrest under a writ of habeas corpus or otherwise. ${ }^{176}$ The statute also allows for arrest without a warrant upon reasonable information that the accused is charged in the courts of

petent evidence to justify holding respondent for trial); Leich, supra note 164, at 158 (reporting revised directive on international extradition issued to all State Department and foreign service personnel).

171. See Unif. Crum. Extradition Act, intro., 11 U.L.A. 97 (1995) (listing jurisdictions wherein Act has been adopted). The Uniform Act implements the extradition clause of the United States Constitution. See U.S. Consr. art. IV, § 2, cl. 2 (providing that "[a] Person charged in any State with Treason, Felony, or other Crime, who shall flee from Justice, and be found in another State, shall on demand of the executive Authority of the State from which he fled, be delivered up, to be removed to the State having Jurisdiction of the Crime"); 18 U.S.C. $§ \S 3182,3194-$ 95 (1994) (providing procedural rules to execute extradition clause of United States Constitution).

172. Unif. CRIm. Extradition Act $\$ 2,11$ U.L.A. at 113 (providing duty of governor in state where person fleeing justice is found).

173. Id. $\S 3$, at 158 (requiring that demand also be accompanied by copy of indictment, information, affidavit and warrant or judgment of conviction or sentence). arrest).

174. Id. $\S 7$, at 296 (providing procedure for issue of governor's warrant of

175. Matter of Lucas, 343 A.2d 845, 850 (N.J. Super. Ct. Law Div.) aff d, 346 A.2d 624 (N.J. Super. Ct. App. Div.), cert. denied, 354 A.2d 306 (N.J. 1975); see also Allen v. Leach, 626 P.2d 1141, 1143 (Colo. 1981) (finding rendition of fugitive permissible as matter of governor's discretion).

176. Unif. CRIM. Extradition Act $\$ 10,11$ U.L.A. at 337-38 (detailing rights of accused person). 
any state with a capital crime or a serious felony. ${ }^{177}$ In the event of such a warrantless arrest, the arrestee may be confined for a period not to exceed thirty days while the governor is given time to issue a warrant under section 6 of the Act. ${ }^{178}$ The warrantless arrest authority adequately covers situations in which the request for extradition or a less formal request to arrest a fugitive is communicated electronically.

\section{G. Extralegal Seizure}

The United States Supreme Court has held that extradition pursuant to a treaty is not the only way in which criminal jurisdiction of someone located in a foreign country can be obtained. As an alternative, the person may be seized and delivered physically into forum-state territory by foreign officers, by private citizens, ${ }^{179}$ or by forum-state law enforcement officials or military personnel. ${ }^{180}$ While these cases involve the assertion of U.S. criminal law, their reasoning, based on international law, would support the assertion of criminal jurisdiction by another country over a person seized and removed from the United States. In United States v. AlverezMachain, ${ }^{181}$ the Supreme Court held that a federal court did not lose jurisdiction over a criminal prosecution because the defendant had been abducted in Mexico and brought to the United States without resort to the extradition treaty then in effect between the two countries. ${ }^{182}$ In so holding, it noted that historical views of international law permit jurisdiction to be exercised even though a person or thing is seized abroad in violation of international law, despite the general principle of international law that one government may not exercise its police power in the territory of another state. ${ }^{183}$ Significantly, the treaty with Mexico did not prohibit abduction nor did it adopt a suggestion of a group of Harvard law

177. Id. $\S 14$, at 406 (detailing circumstances of lawful arrest without warrant).

178. Id. § 15, at 411 .

179. Nadelmann, supra note 163 , at 813 (commenting that historically, most irregular detentions were arranged through private detectives and bounty hunters); $i d$. at 865-68 \& nn.241-53 (noting that recent irregular detentions have involved cooperation between U.S. and local police agents, typically to put fugitives on airplane and send them to U.S. or to international territory where they may be seized by U.S. officials).

180. See United States v. Alvarez-Machain, 504 U.S. 655, 669-70 (1992) (rejecting argument that U.S.-Mexican Extradition Treaty prohibited international abductions); United States v. Noriega, 746 F. Supp. 1506 (S.D. Fla. 1990).

181. 504 U.S. 655 (1992).

182. Id. at $669-70$.

183. Id. at $668-69$. 
professors, advanced as early as 1935 , that "[i]n exercising jurisdiction under this Convention, no State shall prosecute or punish any person who has been brought within its territory or a place subject to its authority by recourse to measures in violation of international law or international convention without first obtaining the consent of the State or States whose rights have been violated by such measures." 184

In other words, the remedies for extralegal obtaining of custody do not include dismissal of the prosecution. ${ }^{185}$ The U.S. Criminal Code ${ }^{186}$ provides that one who commits an offense against the United States may be arrested and imprisoned for that offense, ${ }^{187}$ contemplating the need to reach beyond the territorial boundaries of the United States to obtain the presence of some defendants:

Section 3041 [providing the power of courts and magistrates] of this title shall apply in any country where the United States exercises extraterritorial jurisdiction for the arrest and removal therefrom to the United States of any citizen or national of the United States who is a fugitive from justice charged with or convicted of the commission of any offense against the United States, and shall also apply throughout the United States for the arrest and removal therefrom to the jurisdiction of any officer or representative of the United States vested with judicial authority in any country in which the United States exercises extraterritorial jurisdiction, of any citizen or national of the United States who is a fugitive from justice charged with or convicted of the commission of any offense against

184. Id. at 666 n.13 (quoting Article 16 of Draft Convention on Jurisdiction with Respect to Crime, reprinted in 29 AM. J. INT'L L. 435 (Supp. 1935)).

185. Paul Hoffman et al., Kidnapping Foreign Criminal Suspects, 15 WHITtIer L. REv. 419, 421-33 (1994) (discussing remedies for abduction by U.S. law enforcement agents, including civil liability and criminal prosecution for dismissal of prosecution).

186. The Criminal Code is located in Title 18 of the U.S. Code.

187. 18 U.S.C. $\$ 3041$ (1994). Providing the power of courts and magistrates, $\S 3041$ states:

For any offense against the United States, the offender may, by any justice or judge of the United States . . . at the expense of the United States, be arrested and imprisoned or released as provided in chapter 207 of this title, as the case may be, for trial before such court . . . of the offense. Copies of the process shall be returned as speedily as may be into the office of the clerk of such court, together with the recognizances of the witnesses for their appearances to testify in the case.

Id. 
the United States in any country where it exercises extraterritorial jurisdiction.

Such fugitive first mentioned may, by any officer or representative of the United States vested with judicial authority in any country in which the United States exercises extraterritorial jurisdiction and agreeably to the usual mode of process against offenders subject to such jurisdiction, be arrested and detained or conditionally released pursuant to section 3142 of this title, as the case may be, pending the issuance of a warrant for his removal, which warrant the principal officer or representative of the United States vested with judicial authority in the country where the fugitive shall be found shall seasonably issue, and the United States marshal or corresponding officer shall execute.

Such marshal or other officer, or the deputies of such marshal or officer, when engaged in executing such warrant without the jurisdiction of the court to which they are attached, shall have all the powers of a marshal of the United States so far as such powers are requisite for the prisoner's safekeeping and the execution of the warrant. ${ }^{188}$

The most straightforward and powerful remedy for an extralegal acquisition of jurisdiction over the person of a criminal defendant is to dismiss the prosecution. It was this remedy that was rejected in Alverez-Machain. In 1993, however, the English House of Lords reached a contrary conclusion in Ex parte Bennett, ${ }^{189}$ which mirrored the New Zealand Court of Appeals conclusion in $R v$. Hartley. ${ }^{190}$ The basis for these approaches is the British abuse-ofprocess concept, in which a court refuses to allow its power to be

188. $I d . \S 3042$.

189. R. v. Horseferry Road Magistrates' Court, Ex parte Bennett, [1994] 1 App. Cas. 42 (1993) (holding that trial court had discretion, and perhaps duty, to dismiss criminal prosecution against New Zealand citizen accused of false pretenses in acquisition of helicopter, arrested by South African police and placed on airplane to England; United Kingdom had no extradition treaty with South Africa); see also Andrew L.-T. Choo, Ex parte Bennett: The Demise of the Male Captus, Bene Detentus Doctrine in England?, 5 CRIM. L.F. 165 (1994) (explaining background and uncertainties with respect to Ex parte Bennett).

190. [1978] 2 N.Z.L.R. 199 (C.A. 1977) (suggesting trial court duty to dismiss prosecution procured by telephone call from New Zealand police to Melbourne, Australia, police, followed by arrest of defendant by Australian police and placement on airplane to New Zealand; no effort to obtain extradition warrant). 
used to further wrongdoing by the police. ${ }^{191}$ The rationale for declining prosecution over an unlawfully arrested defendant is thus the same as the rationale for excluding unlawfully obtained evidence.

Although Alverez-Machain says the prosecution could proceed if one were to be kidnapped and brought to court for a crime in the forum state, the forum court may prosecute only for acts which are crimes in the forum. Thus, the court cannot prosecute for a crime under the law of a foreign country. The same limitation would prevent prosecution by a court in the foreign country. It is illuminating to compare this criminal law limitation with long arm service of process in the civil law context. Suppose one were served in country $X$ for suit in a Virginia court for a Virginia tort or breach of contract. The Virginia court would have jurisdiction only if there were purposeful contact with Virginia, and then could apply either Virginia or country $X$ law, depending on the respective interests of Virginia in country $X$. The same result would be obtained if the tort or the breach of contract were committed in country $X$. The only difference would be that choice of law would more likely point to the application of the law of country $X$, and forum non conveniens doctrines would be more likely to make the transfer infeasible, or more likely, the dismissal of the suit in the Virginia courts. If the tort or breach of contract suit were maintained in country $X$, there would be no difficulty in applying Virginia or country $X$ law.

\section{H. Criminal Venue}

The location of a criminal prosecution is determined by the location of the crime and physical custody of the person accused of the crime. A vexing procedural problem arises from the difficulty in determining where a computer crime was committed. A criminal defendant is entitled constitutionally and statutorily to be tried in the place where he allegedly committed the crime. For instance, Article III, section 2 of the United States Constitution guarantees a defendant a trial in the state where the crimes were committed. ${ }^{192}$ The Sixth Amendment entitles criminal defendants to a trial in "the State and district wherein the crime shall have been committed." 193

191. Choo, supra note 189 , at 174 (concluding that primary purpose is not to deter police but rather to refuse misuse of judicial power).

192. U.S. ConST. art. III, $\S 2, \mathrm{cl}$. 3. Trial of crimes committed outside the country must be at such place or places as Congress directs by statute. Id.

193. U.S. Const. amend. VI; see also Travis v. United States, 364 U.S. 631, 633 (1961) (citing 18 U.S.C. $\$ 3237$ (a)) (finding appropriate venue to lie in jurisdiction where offense was begun). 
Federal Rule of Criminal Procedure 18 states that "except as otherwise permitted by statute or by these rules, the prosecution shall be had in a district in which the offense was committed."194 These criminal venue guarantees do not apply to the states ${ }^{195}$ nor to foreign countries. ${ }^{196}$

Many federal criminal statutes provide for venue, but when they do not, the prevailing practice is to apply the "verb test" to determine the nature of the crime alleged and the location of the act or acts constituting it. Under this test, the court looks to the verbs defining the proscribed act and determines where the conduct specified by those verbs actually occurred. That is the place of the crime and the place for prosecution. ${ }^{197}$ As mentioned above, the United States Constitution entitles a criminal defendant to prosecution in the state and district in which the crime was committed. This does not mean, however, that there is a single proper situs for trial in the case of a crime that affects more than one district. ${ }^{198}$ The verb test properly takes into account a number of factors: "the site of the defendant's acts, the elements and nature of

194. Fed. R. CRIM. P. 18; see United States v. Cofield, 11 F.3d 413, 416 (4th Cir.) (reviewing "verb rule," but concluding that witness intimidation offense should be tried by court in which underlying proceeding was pending because it was that court's authority that was jeopardized by witness intimidation), cert. denied, 510 U.S. 1140 (1994); United States v. Kibler, 667 F.2d 452, 454 (4th Cir. 1982).

195. Caudill v. Scott, 857 F.2d 344, 345 (6th Cir. 1988) (affirming denial of habeas corpus based on inapplicability of Sixth Amendment to state prosecution; noting that due process does place some limits on trying state defendant in distant place); Zicarelli v. Dietz, 633 F.2d 312, 325 (3d Cir. 1980) (affirming denial of habeas corpus; extensive review of history and purpose of Sixth Amendment venue clause shows that it should not be applied to states, despite general applicability of some jury provisions of Sixth Amendment), cert. denied, 449 U.S. 1083 (1981).

196. Not one of the major international human rights documents provides for a trial in the country where the crime was committed. In addition, only the International Covenant of Civil and Political Rights even guarantees the right to be tried in one's presence. Paul Sieghart, The International Law of Human RigHTS $\$ 22.6 .3$, cmt. at 295 (1983); see International Covenant of Civil and Political Rights, art. 14(2)(3)(d), 999 U.N.T.S. 171 (1966) ("In the determination of any criminal charge against him, everyone shall be entitled to the following minimum guarantees, in full equality: ... To be tried in his presence ...."). Cf. African Charter on Human and Peoples' Rights, art. 7(1), 21 I.L.M. 59, 60 (1982); American Convention on Human Rights, art. 8(2), 9 I.L.M. 673, 678 (1970); Council of Europe Convention for the Protection of Human Rights and Fundamental Freedoms, art. 6(2), 213 U.N.T.S. 221 (1953); American Declaration of the Rights and Duties of Man, art. XXVI, reprinted in 43 AM. J. INT'L L. 133 (Supp. 1949); Universal Declaration of Human Rights, art. 11(1), reprinted in 43 AM. J. INT'L L. 127 (Supp. 1949).

197. Cofield, 11 F.3d at 417 (reviewing "verb test," but concluding that witness intimidation prosecution should occur before court in which intimidated witness would appear).

198. See United States v. Reed, 773 F.2d 477, 480 (2d Cir. 1985) (reviewing constitutional concept of venue). 
the crime, the locus of the effect of the criminal conduct, and the suitability of each district for accurate factfinding." 199 Usually, the site of the defendant's acts provides proper venue, but other factors may give another venue equal standing. ${ }^{200}$ In particular, the place where the effects of the crime are felt may be an appropriate venue. ${ }^{201}$ Unfortunately, the verb test for criminal venue creates as much ambiguity as the minimum contacts test for personal jurisdiction. For instance, suppose a criminal statute uses the verb "to send, transmit, or distribute." ${ }^{202}$ It is far from certain in Figure 3 above whether any of the actors, the content originator, server $X$ or server $Y$ can be said "to send, transmit, or distribute" the item into jurisdiction $B$.

\section{Choice of Law}

Choice of law, application of foreign criminal law and extraterritorial application of criminal law all are aspects of jurisdiction to prescribe;203 the application of a nation's law to a dispute presupposes that the nation has jurisdiction to prescribe rules applicable to that dispute. The term "choice of law" usually is confined to the universe of civil disputes because of the basic rule that criminal jurisdiction to prescribe is local. Actually, however, criminal jurisdiction to prescribe is not strictly local. ${ }^{204}$ It is thus appropriate for

199. Id. at 481 (enumerating factors).

200. Id.

201. Id. at 481-82 (finding that perjury committed in California could be tried in Southern District of New York because deposition in which perjury occurred was ancillary to proceeding in Southern District of New York; venue for obstruction of justice charge also lay in that district).

202. See, e.g., 18 U.S.C. $§ 2251$ (1994) (child pornography); id. \$§ 1460-69 (obscenity by telephone).

203. See Adam W. Wegner, Extraterritorial Jurisdiction Under International Law: The Yunis Decision as a Model for the Prosecution of Terrorists in U.S. Courts, 22 LAw \& POL'Y INT'L Bus. 409 (1991). There are five preconditions for jurisdiction to prescribe with respect to crimes:

(1) territorial jurisdiction, based on the location of the crime;

(2) national jurisdiction, based on the nationality of the offender;

(3) protective jurisdiction, based on whether the "national interest [is] injured;"

(4) universal jurisdiction, based on the theory that some crimes are so universally condemned that any forum that obtains physical custody of the perpetrator may prosecute on behalf of all humanity, and

(5) passive personal jurisdiction, based on the nationality of the victim.

Id. at 416-17 (citing Restatement (ThiRD) OF the Foreign Relations LaW of the UNITED STATES $\$ \S 402-04,421,431$ (1987); Harvard Research in International Law, Jurisdiction with Respect to Crime, 29 AM. J. INT'L L. 435 (Supp. 1935)).

204. See M. Cherif Bassiouni, International Extradition and World PubLIC ORDER 203-05 (1974) (identifying five theories of jurisdiction recognized by international law as giving rise to rule-making and rule-enforcing power: (1) terri- 
purposes of this Article to consider choice of law or jurisdiction to prescribe in a broad sense, as including both civil and criminal matters. The following sections work through the analytical framework for choice of law in civil matters and then consider three bases for applying the substantive criminal law outside the territory in which the offense actually occurred.

\section{A. Choice of Law in Civil Cases}

As explained above, choice of law is related to personal jurisdiction, venue and enforcement of judgments. Nevertheless, it is a distinct inquiry; a forum may have personal jurisdiction and venue, and nevertheless be obligated by its choice of law rules, perhaps reinforced by the Constitution, to apply the substantive law of another jurisdiction. Historically, choice of law was driven by formal rules such as lex locus contractu, which required the forum to apply the substantive law of the place of contracting to a contracts dispute, and lex locus delicti, which obligated the forum to apply the substantive law of the place of the wrong to a tort claim.

Although these rules were applied by American courts virtually universally, they had their origin in seventeenth and eighteenth century private international law, which adapted itself well to the American federal system with the states as independent sovereigns. ${ }^{205}$ Joseph Story's 1834 treatise on conflict of laws was the first effort to synthesize standard rules in this area, and his preface noted the importance of the subject for trade between foreign states and between the different states of the American union; he also noted that much of the learning on the subject was derived from the work of continental European civil law commentators. 206

Despite their unambiguous expression, the traditional rules required considerable interpretation. For example, the place of contracting might be the place of making a contract, or it might be the place of performance. ${ }^{207}$ The place of wrong in a tort claim might be the place where the defendant acted or the place where the in-

torial; (2) active personality or nationality, based on nationality of accused; (3) passive personality, based on nationality of victim; (4) protective, based on national interest affected; and (5) universality, based on international character of offense).

205. See ANTON \& BeAumont, supra note 23, at 12 (noting utility of well-developed American choice-of-law doctrine as basis for private international law, because issues are same).

206. STORY, supra note 2 , intro.

207. Id. $\$ 233$, at $353-55$ (explaining differing views on whether place of making or place of execution should govern contract). 
jury occurred. ${ }^{208}$ By the latter third of the twentieth century, most courts and commentators agreed on a more flexible "interests analysis" approach to resolving choice of law questions. In many cases, the traditional rule produces the same results as the interest analysis. ${ }^{209}$

The analysis for tort claims-such as a GII defamation claimrequires determining the state with the most significant relationship to the occurrence and the parties, including consideration of the place where the injury occurred, the place where the conduct causing the injury occurred, the domicile, residence, nationality, place of incorporation and place of business of the parties, and the place where any relationship between the parties is centered. ${ }^{210}$ Contract cases are adjudicated according to the law chosen by the parties or, in the absence of any such chosen law, by the law of the state which has the most significant relationship to the transactions and the parties with respect to a particular issue. ${ }^{211}$ The most significant relationship is determined based on the place of contracting, the place of negotiation of the contract, the place of performance, the location of the subject matter of the contract, and the domicile, residence, nationality, place of incorporation and place of business of the parties. ${ }^{212}$ "If the place of negotiating the contract and the place of performance are in the same state, the local law of this state will usually be applied . . . ."213

There are limitations on a party's choice of law. The general

208. Story put lex locus delicti this way:

The doctrine of the common law is so fully established on this point, that it would be useless to do more than to state the universal principle, which it has promulgated; that is to say, that in regard to the merits and rights involved in actions, the law of the place where they originated, is to govern .... But the forms of remedies and the order of judicial proceedings are to be according to the law of the place where the action is instituted, without any regard to the domicil[e] of the parties, the origin of the right, or the country of the act.

$I d$. $\S 558$, at 934 .

209. See Laxalt v. C.K. McClatchy, 116 F.R.D. 438, 449-51 (D. Nev. 1987) (concluding that Nevada shield law applied both under traditional place of wrong and under interest analysis because virtually entire distribution occurred in Nevada and no printing occurred in California); Levine v. CMP Publications, Inc., 738 F.2d 660, 667 (5th Cir. 1984) (stating that law of plaintiff's domicile usually governs defamation actions and that most significant relationship test leads to same conclusion on facts) (citing RESTATEMENT (SECOND) OF CONFLiCT OF LAWS § 150(2) (1971)).

210. Restatement (Second) of Conflict of Laws $\$ 145$ (1971).

211. Id. $\S 186$ (general rule); id. $\S 187$ (law of state chosen by parties); id. $\S 188$ (law governing in absence of effective choice by parties).

212. Id. $\S 188$.

213. Id. § $188(3)$. 
rule is that their choice will govern "if the particular issue is one which the parties could have resolved by an explicit provision in their agreement directed to that issue."214 In other words, if the parties could explicitly provide detailed ground rules for determining whether performance met the requirements of the contract, they could choose the law of a state to decide whether performance was sufficient. Even if they could not have explicitly governed the issue, they can choose a state's law unless the chosen state has no reasonable relationship to the parties or the transaction and there is no other reasonable basis for the party's choice, or if application of the law of the chosen state would contravene a fundamental public policy of a state which has a materially greater interest in determination of the particular issue. ${ }^{215}$ The Restatement of Conflicts of Laws specifically contemplates the possibility of party choice of the law of a jurisdiction well known to them even though that state has no relationship to the contract:

When contracting in countries whose legal systems are strange to them as well as relatively immature, the parties should be able to choose a law on the ground that they know it well and that it is sufficiently developed. For only in this way can they be sure of knowing accurately the extent of their rights and duties under the contract. ${ }^{216}$

The language of the Restatement apparently contemplates that the only law eligible for choosing is the law of a particular state, ${ }^{217}$ thus excluding the possibility of the parties choosing general legal principles such as UNIDROIT or lex mercatoria.

Constitutional due process requirements constrain choice of law to some extent, but Supreme Court jurisprudence on the relationship between due process and choice of law is in an uncertain state. In Sun Oil Co. v. Wortman, ${ }^{218}$ five Justices agreed on the soundness of the doctrine that the Constitution does not bar the application of a forum state statute of limitations to claims that in their substance are governed by the law of a different state. ${ }^{219}$ The Court held that " $[t]$ he Full Faith and Credit Clause does not compel 'a state to substitute the statutes of other states for its own stat-

214. $I d . \S 187(1)$.

215. $I d . \S 187(2)$.

216. Id. $\$ 187 \mathrm{cmt}$. f.

217. Id. $\S 187$ (1) (stating "the law of the state chosen by the parties" (emphasis added)).

218. 486 U.S. 717 (1988).

219. Id. at 722 . 
utes dealing with a subject matter concerning which it is competent to legislate.' "220 The procedural rules of its courts are matters on which a state is competent to legislate. Thus, a state may apply its own procedural rules to actions litigated in its courts. A statute of limitations is procedural for this purpose, and therefore, a state court may apply its own statute of limitations. ${ }^{221}$ The issue on which controversy existed, however, was whether a statute of limitations should be considered procedural for this purpose. 222 The early cases, looking to international law, uniformly held that the forum statute of limitations governed. ${ }^{223}$ The majority rejected the argument that Guaranty Trust v. York, ${ }^{224}$ which treated statutes of limitations as substantive for Erie purposes, should govern because the words "substantive" and "procedural" do not have precise content. ${ }^{225}$ Because of the long-standing tradition under the Full Faith and Credit Clause, a due process challenge similarly must fail. ${ }^{226}$ Justice Brennan reached the same result through interest analysis:

Given the complex of interests underlying statutes of limitations, I conclude that the contact a State has with a claim simply by virtue of being the forum creates a sufficient procedural interest to make the application of its limitations period to wholly out-of-state claims consistent with the Full Faith and Credit Clause. This is clearest when the forum State's limitations period is shorter than that of the claim State. 227

On the other hand, when, as in the case before him, the forum state's limitation period was longer, the interests of the forum state were less clear. Because the various choice of law arguments were fairly balanced and somewhat ambiguous, Justice Brennan concluded that the Constitution permitted the choice the forum state made to apply its own limitations period. 228 The balance of the case involved disagreement over whether Kansas correctly inter-

220. Id. (quoting Pacific Employers Ins. Co. v. Industrial Accident Comm'n, 306 U.S. 493, 501 (1939)).

221. Id.

222. Id. at 722-23.

223. Id. at 724-25.

224. 326 U.S. 99 (1945).

225. Sun Oil, 486 U.S. at 726-27.

226. $I d$. at 726-27, 729-30.

227. Id. at 737 (Brennan, J., concurring).

228. Id. at 739 (Brennan, J., concurring). Justice Brennan essentially disagreed with the majority's reliance on long established constitutional tradition. Id. at 740 (Brennan, J., concurring). 
preted the substantive law of Texas, Oklahoma and Louisiana. ${ }^{229}$

Three years earlier, in Phillips Petroleum Co. v. Shutts, ${ }^{230}$ the Supreme Court reviewed a case in which the Kansas courts applied Kansas law to a class action, notwithstanding that over ninety-nine percent of the gas leases involved in the case and ninety-seven percent of the plaintiffs had no connection with the state of Kansas except for the lawsuit. ${ }^{231}$ The Court began by noting that in Allstate Insurance Co. v. Hague, ${ }^{232}$ a plurality recognized that the Due Process Clause and the Full Faith and Credit Clause provide only modest restrictions on the application of forum law: " 'for a State's substantive law to be selected in a constitutionally permissible manner, that State must have a significant contact or significant aggregation of contacts, creating state interests, such that choice of its law is neither arbitrary nor fundamentally unfair.' "233 Applying this standard, the Court considered the fact that the defendant owned property and conducted substantial business in the state, and the fact that none of the plaintiffs had opted out of the class too tenuous to support application of Kansas law. Fairness, it held, depends importantly on the expectations of the parties, and "there is no indication that when the leases involving land and royalty owners outside of Kansas were executed, the parties had any idea that Kansas law would control."234 It declined the Kansas Supreme Court's suggestion that more relaxed standards should apply to nationwide class actions. ${ }^{235}$ Justice Stevens would have affirmed, however, because he saw no real conflict among the laws of the various states having significant contact. 236

Because GII transactions frequently permit actor, intermediaries and victim to be widely separated geographically, interest analysis requires careful scrutiny of the technology and the facts of a particular transaction. Consider a hypothetical situation in which an Internet server in California makes available material that users in Tennessee find offensive. In a lawsuit filed by the Ten-

229. Compare id. at 730-34 (majority explaining why law of all four states permitted conclusion drawn) with id. at 743-44 (O'Connor, J., dissenting in material part) (explaining why Kansas misconstrued laws of other states).

230. 472 U.S. 797 (1985).

231. Id. at 815-16 (characterizing contacts).

232. 449 U.S. 302 (1981) (declining to invalidate choice of law on constitutional grounds).

233. Phillips, 472 U.S. at 818 (quoting Allstate Ins., 449 U.S. at 312-13).

234. Id. at 822 .

235. Id. at $820-21$.

236. Id. at 823-24, 834 ("[M]ere misconstruction by the forum of the laws of a sister state is not a violation of the Full Faith and Credit Clause."). 
nessee users against the California server operator, say for intentional infliction of emotional distress, the choice of law question would be whether Tennessee or California law should apply. Assuming there is a difference between the substantive law of the intentional-infliction tort in the two states, Tennessee may have the most significant interests. It seeks to protect its residents against extreme emotional distress intentionally inflicted by others. California, of course, also has interests, such as in seeing its citizens free to publish material that would not under California standards be tortious. But under the Supreme Court's tests outlined above, there would be sufficient Tennessee interest to allow the application of Tennessee law and the refusal of a Tennessee court to apply California law.

Cases involving defamation claims against interstate publishers offer some analogies to GII activities. ${ }^{237}$ In these cases, there is a rule that the most significant interest is where the "sting was felt," which usually leads to the domicile of the plaintiff in defamation cases. ${ }^{238}$ Many courts apply a nine-factor test in defamation cases involving more than one state: (1) the state of plaintiff's domicile; (2) the state of plaintiff's principal activity to which the defamation relates; (3) the state where plaintiff suffered greatest harm; (4) the state of publisher's domicile or incorporation; (5) the state where defendant's main publishing office is located; (6) the state of principal circulation; (7) the state of emanation; (8) the state where

237. Jean v. Dugan, 20 F.3d 255, 261 (7th Cir. 1994) (affirming district court's choice of Indiana law; Indiana had most significant contacts to defamation; reputational injury occurred in Indiana although publication occurred both in Indiana and Illinois; defamatory article originated in Illinois); Brown v. Hearst Corp., 862 F. Supp. 622, 627 (D. Mass. 1994) (noting Massachusetts had most significant relationship to defamation claim based on broadcast that originated in Massachusetts and was shown in Massachusetts and surrounding states; plaintiff apparently lived in Texas), aff'd, 54 F.3d 21 (1st Cir. 1995). But see Chevalier v. Animal Rehabilitation Ctr., Inc., 839 F. Supp. 1224, 1229 (N.D. Tex. 1993) (concluding that place of injury is de-emphasized in multi-state defamation cases under RESTATEMENT (SECOND) OF CONFLICTS OF LAWS $\$ 145 \mathrm{cmt}$. e (1971); party relationship centered in Texas, Texas was place of injury, many defendants reside in Texas and others injected themselves into Texas activities and most conduct occurred in Texas; therefore, Texas has most significant relationships).

238. Buckley v. McGraw-Hill, Inc., 782 F. Supp. 1042, 1047 (W.D. Pa. 1991) (holding that ordinarily, law of domicile of plaintiff represents most significant contacts with defamation claim, but stipulation by parties that New York law should be applied was honored because New York also had interest in dispute), aff' $d, 968$ F.2d 12 (3d Cir. 1992). Privilege is determined by the law of state with the most significant contacts. See Washington Nat'l Ins. Co. v. Administrators, 2 F.3d 192, 195-96 (7th Cir. 1993) (concluding that "sting" of defamation was felt in Iowa and thus Iowa law determined privilege of Illinois defendant). 
libel was first seen; and (9) the state of the forum. ${ }^{239}$ Each factor, however, does not receive the same weight. For example, in Hoffman $v$. Roberto, ${ }^{240}$ the plaintiff filed a defamation claim arising from union officials' statements in telex messages sent to various states claiming that the plaintiff diverted funds of an employer. Because of the multiple states of publication, the district court looked to the place of conduct, the residences or places of business of the parties and the place where the relationship was centered. ${ }^{241}$ As the first two of these inquiries were indeterminative, the court concluded that Michigan law, where the employment relationship was centered, should be applied. ${ }^{242}$

Using the preceeding defamation choice of law cases as an analogy, domicile will likely govern defamation actions arising in the GII. Invasion of privacy claims, like defamation claims, are centered where the plaintiff lives and conducts his or her affairs, because that is where the privacy interest exists. ${ }^{243}$ The same result is appropriate for intellectual property infringement actions ${ }^{244}$ unless the party arguing for the choice of different law can show that adversely affected markets are located elsewhere. Intellectual property claims primarily involve injuries to markets, and the location of the markets should drive the interest analysis.

\section{B. Extraterritorial Application of Criminal Statutes}

International and American law recognize the legitimacy of giving extraterritorial effect to the criminal laws of a national sovereign. The extension of criminal jurisdiction is particularly likely in two circumstances: when the actor, and potential criminal defendant, is a citizen of the state whose law is to be applied, and when the "effects test" shows that a non-national has engaged in extraterritorial conduct with the intention or the likelihood that it will have effects in the country whose law is to be applied. ${ }^{245}$ In addition to

239. See Zerman v. Sullivan \& Cromwell, 677 F. Supp. 1316, 1318-19 (S.D.N.Y. 1988) (enumerating nine factors and determining that none of them usually overruled contacts in state of plaintiff's domicile).

240. 578 N.E.2d 701 (Ind. Ct. App. 1991) (affirming dismissal of lawsuit by president of corporation against union).

241. Id. at 705 .

242. $I d$. at 705-06.

243. The same reasoning holds true of emotional distress claims.

244. Of course, choice of law is less important in patent and copyright claims, because federal law applies. It may be important, however, in trademark, unfair competition and trade secrets claims.

245. United States v. Juda, 46 F.3d 961 (9th Cir.) (affirming denial of motions to dismiss and to suppress evidence seized on high seas from boat on which beeper had been placed by Australian law enforcement authorities), cert. denied, $115 \mathrm{~S}$. Ct. 
international crimes, international law recognizes, with some dispute, the possibility of passive personal jurisdiction to apply to criminal law. This basis allows a nation to prosecute anyone committing a crime against one of that nation's citizens, regardless of where the crime was committed. ${ }^{246}$

Both branches of extraterritorial criminal jurisdiction have counterparts in civil personal jurisdiction and choice of law analysis. The nationality branch of extraterritorial criminal jurisdiction corresponds to extending personal jurisdiction in a civil case over one who is domiciled in the forum state. The effects test corresponds to minimum contacts analysis in civil personal jurisdiction, especially insofar as it authorizes the assertion of personal jurisdiction in a civil case over one who acts outside the jurisdiction intending that contact with the jurisdiction will result from that person's conduct. ${ }^{247}$ The cases reviewed above involving the assertion of personal jurisdiction over publications that publish outside the state, but intending that their publication come into the state, are clear

2632 (1995). The court held that under international law, a nation may generally assert jurisdiction over its citizens, over stateless vessels and over all individuals arrested on board a stateless vessel. Id. at 967 . More particularly, it found permissible the application of 18 U.S.C. $\$ 81$ (1994), criminalizing arson, to a deliberate fire set aboard the stateless vessel in international waters. "There is no reason for any other nation to exercise jurisdiction. The exercise of jurisdiction over the arson is not arbitrary or fundamentally unfair." Juda, 46 F.3d at 967 . It rejected arguments that the evidence seized from the vessel should be excluded because the placement of the beeper was impermissible. Id. The court of appeals found that the foreign search occasioned by placement of the beeper record was not unreasonable because it conformed to the requirements of Australian law.

A DEA agent was told by a Superintendent with the Drug Operations Branch, International Division of the Australian Federal Police, that no warrant was required under Australian law and that an Australian officer would assist with the installation of the transmitter. The DEA agent reasonably relied on that representation, and accordingly, the good faith exception to the exclusionary rule applies.

$I d$. at 968 . Independently, the court of appeals rejected the argument that monitoring the location of the vessel by listening to transmissions from the beeper was a search within the Fourth Amendment. "There is no privacy right in one's location on the high seas." Id. at 968.

Historically, civil law countries had more expansive notions of extraterritorial criminal jurisdiction, always recognizing the possibility of prosecuting their own nationals for crimes committed outside their territory. Nadelmann, supra note 163, at 833-34 \& nn.83-89 (noting instances in which civil law criminal jurisdiction was extended extraterritorially based on crimes in which nationals were victims). More recently, the United States has come to recognize this basis for extraterritorial application of its own criminal law. Juda, 46 F.3d at 961 .

246. Wegner, supra note 203 , at $426-30$ (explaining controversy over passive personal jurisdiction principles but urging its acceptance as one of several bases for prosecuting international terrorists).

247. See World-Wide Volkswagen Corp. v. Woodson, 444 U.S. 286 (1980). 
examples. ${ }^{248}$

In general, there is no constitutional bar to the extraterritorial application of U.S. penal law. ${ }^{249}$ Extraterritoriality is determined by looking to congressional intent, presuming that Congress does not want to violate international law. ${ }^{250}$ Thus, unless Congress explicitly directs otherwise, extraterritoriality is valid to the extent permitted by international law. 251 Additionally, choice of law does not arise in criminal cases in the same way that it arises in civil cases. The basic reason for this is that crimes were not traditionally considered transitory ${ }^{252}$ and thus a court either had jurisdiction or it did not. When a court had jurisdiction, it applied its own law, 253 but a wide range of extraterritorial conduct might still be criminal. ${ }^{254}$ Therefore, one could be criminally liable in state $A$ for computer-triggered conduct in state $B$ that caused injury in state $A$ as long as state $A$ expressly prohibited extraterritorial conduct of that character and the actor knew or should have known of the adverse effect in state $A .^{255}$ Extraterritorial application of criminal law by multiple nations has some advantages, at least when the substantive

248. See generally United States v. Noriega, 746 F. Supp. 1506, 1512 (S.D. Fla. 1990) ("[A] country may regulate the acts of its citizens wherever they occur."). The United States also has long possessed the ability to attach criminal consequences to acts occurring outside this country which produce effects within the United States; international law principles have expanded to permit jurisdiction upon a mere showing of intent to produce effects in this country, without requiring proof of an overt act or effect within the United States. Id. "For example, the United States would unquestionably have authority to prosecute a person standing in Canada who fires a bullet across the border which strikes a second person standing in the United States." Id. at 1512-13.

249. United States v. Vasquez-Velasco, 15 F.3d 833 (9th Cir. 1994) (affirming conviction of Mexican citizen and resident under U.S. statute prohibiting violent crimes committed in aid of racketeering enterprise).

250. Id. at 839-40.

251. Id. at 840 .

252. Transitory causes of action, as distinguished from local causes of action, were a kind of property that traveled with the plaintiff. The plaintiff could assert the claim representing this species of property wherever he or she happened to be-assuming the court in which the plaintiff filed had personal jurisdiction over the defendant.

253. See Restatement (Second) of Conflict of Laws $\$ 89$ (1971) ("[N]o action will be entertained on a foreign penal cause of action.").

254. See Model. Penal Code $\$ 1.03$ (1994). The Model Penal Code allows a conviction "in this state" committed by conduct occurring within the state or conduct occurring outside the state sufficient to constitute an attempt, conspiracy, an extraterritorial omission to perform a legal duty imposed by domestic law with respect to a person, thing or transaction in the state, or when extraterritorial conduct is expressly prohibited by a domestic statute when the conduct bears a reasonable relation to a legitimate interest of the state and the actor knows or should know that his or her conduct is likely to affect that interest. Id.

255. Id. § $1.03(1)(\mathrm{f})$. 
criminal law being applied extraterritorially is more or less the same. "Concurrent jurisdiction had the considerable virtue of permitting any nation catching an offender to act upon his wrongswithout resolving the fine points of a theory of exclusive jurisdiction, and without facing the political, moral and legal concerns of aiding a foreign system of justice."256

\section{Enforcement of Foreign Criminal Law}

As explained above, choice of law does not function in the criminal arena the way it does in the civil arena. Strict localization of criminal law ${ }^{257}$ leads to the usual conclusion that the courts of one jurisdiction may not apply the criminal laws of another. Therefore, "[a] court in the United States may try a person only for violation of United States law, not for violation of the penal law of a foreign state."258 The Restatement (Third) of Foreign Relations notes that some civil law countries try persons whom they cannot extradite for crimes committed in other countries. ${ }^{259}$ This constitutes a kind of "transitory" criminal action.

In common law systems, such as at the state level in the United States, one can argue that a state court would have the power to try

256. Ruth Wedgwood, The Revolutionary Martyrdom of Jonathan Robins, 100 YALE L.J. 229, 239 (1990) (reviewing controversial instance of extradition of mutineer in early American history; explaining why piracy was treated as international crime). Accord Wegner, supra note 203, at 421-24 \& nn.71-98 (explaining evolution of universal jurisdiction, beginning with privacy and now extending to number of different crimes, and favoring broad interpretation of universal jurisdiction (citing Restatement (Third) of Foreign Relations Law of the United States $§ 404$ (1987))).

257. See generally In re Lo Dolce, 106 F. Supp. 455 (W.D.N.Y. 1952) (refusing extradition to Italy of person accused of murder because alleged murder was committed outside territory effectively controlled by Italy during Second World War).

258. Restatement (ThiRD) Of Foreign Relations, supra note 256, § 422(1). See generally United States v. Hudson and Goodwin, 11 U.S. (7 Cranch) 32 (1812) (holding that federal courts may not convict for common law crimes, but only for crimes for which jurisdiction is vested by statute). The rationale in Hudson and Goodwin was that federal government institutions are institutions of limited jurisdiction and must respect separation of powers. This rationale precludes federal court jurisdiction over crimes defined by foreign states because that jurisdiction has not been given to the courts by Congress. Of course, it permits Congress to define a foreign crime as a U.S. crime within the jurisdiction of a United States federal court.

259. Restatement (ThiRd) of Foreign Relations $\$ 422$ reporters' notes 3 (1987). Some commentators suggest that civil law countries are more or less willing to prosecute their own nationals for violation of the foreign criminal law as long as a sort of dual criminality principle is satisfied. Nadelmann, supra note 163, at 885 (identifying German prosecution of Hungarian national for crimes committed in Hungary, but contrasting U.S. law; characterizing principle as aut dedere, aut iudicare). 
an actor for the foreign crime because state courts are not limited by the separation of powers doctrine of the federal Constitution. There are at least some states in which common law crimes exist, albeit mostly in theory. In such a state, the courts are not bound only to those crimes declared expressly to be so by statute. Furthermore, they would have the power to apply foreign criminal definitions, unless some overriding constitutional privilege would be infringed by doing so. This would, of course, be a revolutionary idea; the linkage between territorial sovereigns and substantive criminal law is very strong. ${ }^{260}$

Even if the territorial problems described above are overcome, there still exists the need for an affirmative basis for the criminal proscription for which the defendant is prosecuted. It surely would violate procedural due process to prosecute for a crime that was not defined as such when the defendant acted. ${ }^{261}$ Therefore, the prosecution would need to establish either a sufficient connection between the defendant's conduct and the foreign jurisdiction whose criminal law is being relied on, or else a basis in international law as might be the case with piracy or terrorism. ${ }^{262}$

\section{International Crimes $^{263}$}

The concept of international "universal" crimes has been recognized for over 150 years. ${ }^{264}$ Notwithstanding the dominant prin-

260. See, e.g., United States v. Gecas, 50 F.3d 1549 (11th Cir. 1995) (reversing district court and extending Fifth Amendment privilege against self-incrimination to prosecution under laws of foreign country). Gecas illustrates the depth of sovereign-specificity of criminal law, even while recognizing a privilege under the U.S. Constitution when foreign prosecution is shown to be likely. By requiring the one asserting the privilege to demonstrate probability of extradition, the doctrine acknowledges the safety from prosecution under the laws of country $A$ of one physically in country $B$, absent a possibility of extradition. The court's analysis also acknowledged the traditional concerns that the criminal law of country $A$ might offend the policy of country $B$, and the difficulty of $B$ keeping track of the criminal laws of all the As in the world. Id. at 1566.

261. See Marks v. United States, 430 U.S. 188, 192 (1977) (declining to give retroactive effect to standards articulated in state supreme court opinion because that would violate due process by criminalizing conduct not criminal when it occurred).

262. See United States v. Layton, 855 F.2d 1388, 1396-97 (9th Cir. 1988) (holding that district court would have jurisdiction to try national of United States for committing crime against internationally protected person even if national's acts occurred outside territory of United States), cert. denied, 489 U.S. 1046 (1989).

263. Research and drafting for this section was done by Sean P. Lugg, Villanova Law School Class of 1996, law clerk to the author.

264. See generally Tel-Oren v. Libyan Arab Republic, 726 F.2d 774, 781 (D.C. Cir. 1984) (explaining that piracy is so-called "international crime;" pirate is considered enemy of every state and can be brought to justice anywhere; further, every state can punish crimes like piracy or slave trade on capture of criminal, whatever 
ciple that criminal law is a strictly national proposition, there have long existed a few crimes that are characterized as international or universal, and thus punishable in any jurisdiction obtaining custody of the actor. Piracy was one such crime. ${ }^{265}$ In this century, air piracy and certain other acts of terrorism have been added to the list, albeit by treaty, as much as by the extension of customary international law. Quite recently, the move toward an international criminal court has focused attention on enumerating additional international crimes. ${ }^{266}$ The American Journal of International Law notes:

[T] here is little or no international criminal law in the real sense of the term. There is some legislation and some rules regarding the competence of courts in respect to certain extra-territorial crimes, but aside from a few acts, such as piracy ... [and] the circulation of obscene publication... there is no international criminal legislation, nor is there as yet any international judicial or police machinery of repression. ${ }^{267}$

Additionally, the German code addressing the issue of international crimes provides: “ ' $[I]$ nternational interests that trigger German jurisdiction' include crimes involving atomic energy, explosives and radiation; attacks on air traffic; unauthorized dealings in narcotics; dissemination of pornography; encouraging prostitution; counterfeiting and economic subsidy fraud."268 Moreover, "the German Constitution provides that any international law is by definition part of German law."269

International crimes are defined by treaties and by customary

his or her nationality), cert. denied, 470 U.S. 1003 (1985); Edwin D. Dickinson, Is the Crime of Piracy Obsolete?, 38 HARv. L. REv. 334, 335 (1925) (stating that piracy has "long been regarded" as both international and municipal law crime); Surena et al., supra note 167, at 383; Wegner, supra note 203, at 421-24 (embracing universal criminal jurisdiction as good framework for punishing terrorists). For a further discussion of international computer terrorism, see appendix, infra notes 536-82 and accompanying text.

265. The wording of the U.S. piracy statute makes it clear that international law is being applied: "Whoever, on the high seas, commits the crime of piracy as defined by the law of nations, and is afterwards brought into or found in the United States, shall be imprisoned for life." 18 U.S.C. \$ 1651 (1994).

266. For a further discussion of the proposed International Criminal Court, see infra notes 522-23 and accompanying text.

267. Surena et al., supra note 167, at 385 (citing James W. Garner, Book Review, 16 AM. J. INT'L L. 493 (1922) (reviewing H. DONNEDIEU DE VABRES, INTRODUC. tion Á L'Etude du Drort Pénal International (1922))) (emphasis added).

268. Id. at 386 (quoting German Criminal Code) (emphasis added).

269. Id. 
law. Customary law, though, is criticized as being vague, and in many respects archaic. There is no standardized codification of international offenses; rather, enforcement is generally left to extradition treaties. "For example, the Webster-Ashburton Treaty of 1842 between the United States and Great Britain covered . . . murder, piracy, arson, robbery, forgery and the utterance of forged paper as extraditable offenses." ${ }^{270}$ Moreover, the United States presently maintains over 100 foreign extradition treaties, more than forty of which are dual criminality extradition treaties.271 Additionally, one respected international law scholar found twenty-two categories of international crime in 312 multilateral instruments written from 1815 to 1985 :

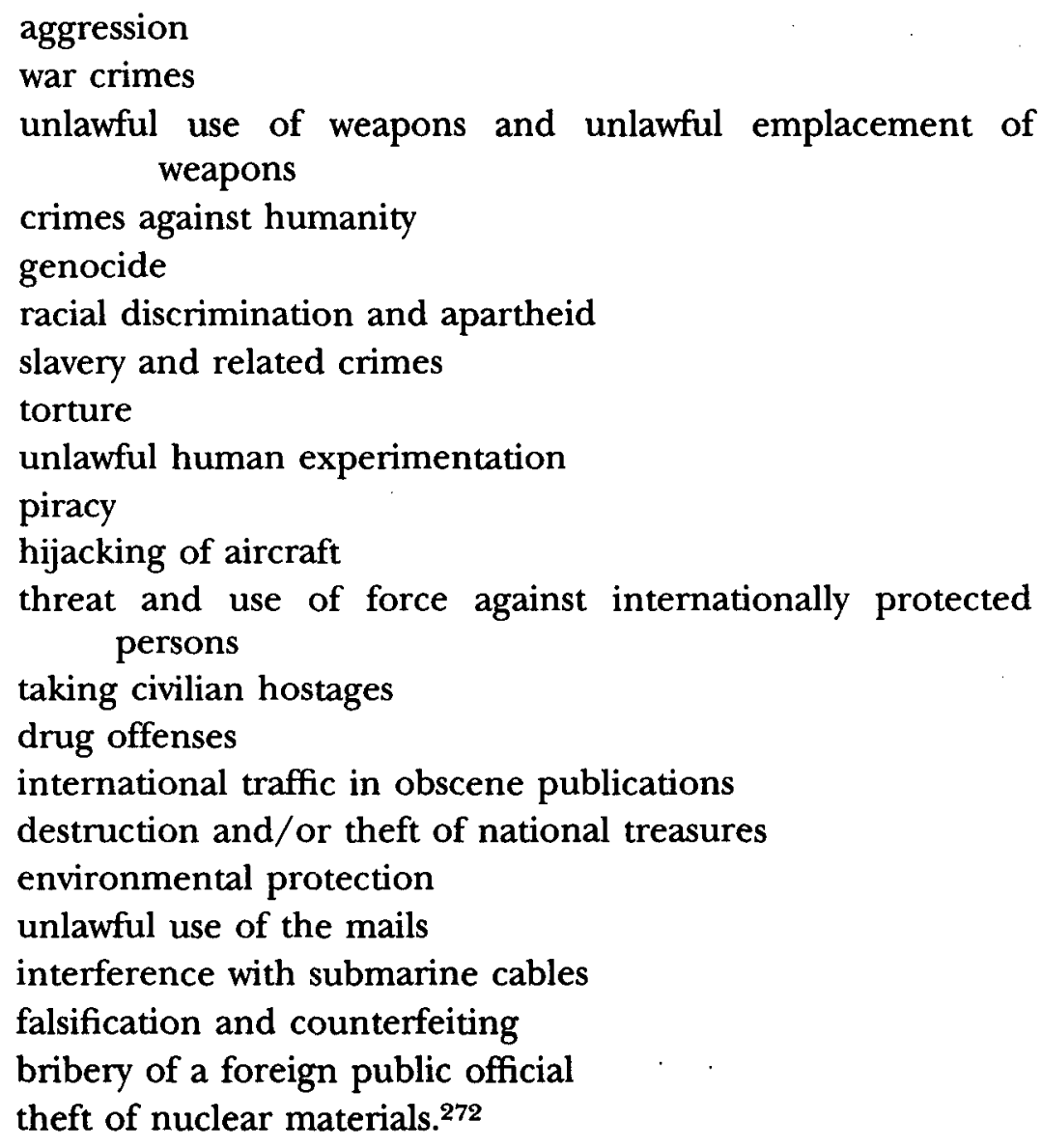

270. Id. at 384. This treaty was expanded in 1889. Id.

271. Id. at 383-84. Under the principle of dual criminality, a defendant is extraditable if the offense committed is "punishable by a specified minimum sentence, usually one year, in both countries." Id. at 384 .

272. Barbara M. Yarnold, International Fugitives: A New Role for the 
The "obscene publications" and "interference with submarine cables" items above are interesting in the GII context, the one because of concern with obscene traffic on the Internet, the other because it exemplifies the legitimacy of internationalizing crimes against the communications infrastructure. There have been recent efforts to develop a code (a multilateral treaty) of international crimes in conjunction with the effort, considered below, to develop an international criminal court. The code could, of course, be effective even without an international criminal court because it would harmonize the bases of universal criminal jurisdiction for application by national courts.

\section{ENFORCEMENT OF JUDGMENTS}

Enforcement of civil judgments is accomplished by executing against property owned by the judgment debtor. Enforcement of criminal judgments ordinarily requires obtaining custody of the defendant so he or she may be incarcerated, thus implicating the same concepts as extradition and extralegal methods of obtaining custody reviewed above in connection with criminal personal jurisdiction. In addition, some criminal judgments can be enforced by the forfeiture of property. This possibility, combined with injunction enforcement in the civil context, creates an area of overlap between criminal and civil judgment enforcement, and is discussed below.

\section{A. Enforcement of Civil Judgments}

Section III above explained that personal jurisdiction, venue, choice of law and judgment-enforcement are interrelated. Thus, one should consider the analysis of judgment enforcement in this section along with the analyses of these related issues. The GII produces few interesting problems when a dispute and a resulting civil judgment are entirely local; the victor-the judgment creditorsimply gets a writ of execution under local procedure and has the sheriff levy on such personal or real property of the judgment debtor as can be found. ${ }^{273}$ The problems of turning a judgment

InTERnational Court of Justice (1991) (citing generally M. Cherif Bassiouni, A Draft International Criminal Code and Draft Statute for an INTERNational. Criminal Tribunal (1987)). For a further discussion of international computer terrorism, see appendix, infra notes 536-82 and accompanying text.

273. See, e.g., FED. R. Crv. P. 69 (incorporating state judgment execution procedure); ILL. CODE OF Crv. P. art. 12 (West 1995) (enforcing judgments); IowA R. Crv. P. Drv. X (West 1995) (same); Kan. R. Crv. P. art. 24 (West 1994) (explaining procedures for executions and orders of sale). 
into liquid assets become more difficult when the judgment comes from another state or from another country. Thus, a plaintiff may have obtained a judgment against an Internet service provider in an Alabama circuit court, but find assets worthy of executing against only in Virginia. Execution therefore must be sought in a Virginia court based on the "foreign judgment" from Alabama. Alternatively, an author in Sweden may obtain a judgment in a Swedish court for copyright infringement resulting from an act by the operator of an Internet server in Massachusetts. In order to obtain monetary relief, the victim must enforce the Swedish judgment against assets held by the server operator in Massachusetts. ${ }^{274}$

In both of these cases, the first step conceptually is to obtain recognition of the judgment. When the foreign judgment is from another American state, the Full Faith and Credit Clause of the United States Constitution obligates the enforcing state to recognize it. When the foreign judgment is from another country, either state statutory law (such as the Uniform Recognition Act, enacted in about half the states ${ }^{275}$ ) or comity ${ }^{276}$ prescribe the criteria for recognition. Basically, courts must recognize foreign judgments unless the party opposing recognition can show violations of procedural due process or lack of personal jurisdiction by the rendering court, ${ }^{277}$ or in rare instances, if the opposing party can demonstrate that enforcement of the judgment would violate public policy in the recognition state. ${ }^{278}$

Comity is a doctrine developed over several centuries. These basic international law principles are expressed in the Restatement provisions dealing with the enforcement of foreign judgments, ${ }^{279}$

274. A new concept, worth developing in greater depth, would proceed from the model of in rem jurisdiction, and conclude that a judgment supported by personal jurisdiction in the form of electronic presence could be enforced only against the electronic persona, either against assets in the jurisdiction or by excluding that person from electronic contact with that jurisdiction. The author appreciates this suggestion from his friend David R. Johnson.

275. Unif. Foreign Money-Judgments Recognition Act, 13 U.L.A. 261 (1962) [hereinafter UNIFORM RECOGNITION ACT].

276. See de la Mata v. American Life Ins. Co., 771 F. Supp. 1375 (D. Del. 1991) (discussing comity).

277. STORY, supra note $2, \S 586$, at 978 (concluding that it is universally accepted that foreign judgment not supported by jurisdiction is treated as mere nullity, entitled to no respect). The procedural due process standard is essentially American in character.

278. Matusevitch v. Telnikoff, 877 F. Supp. 1, 4 (D.D.C. 1995) (declining to recognize or to enforce British libel judgment under Maryland's Uniform Recognition Act because British libel law lacked constitutional protections applied in United States).

279. Restatement (Second) of Judgments $\$ \S 81,82$ (1982). 
summarizing the doctrine of comity:280 "A valid judgment rendered in a foreign nation after a fair trial in a contested proceeding will be recognized in the United States so far as the immediate parties and the underlying cause of action are concerned." ${ }^{281}$ When the conditions are met, the effect to be accorded foreign judgments is the same as is required under the Full Faith and Credit Clause. ${ }^{282}$ Qualifying foreign judgments may be enforced. ${ }^{283}$ Equitable decrees from foreign courts also generally are enforceable in the United States as long as they meet the basic requirements set forth in section 98 of the Restatement. ${ }^{284}$

Overlaid on the comity doctrine are positive law enactments, such as the above-mentioned Uniform Recognition Act, adopted in about half of the states. This legislation provides a framework for U.S. recognition of judgments from foreign countries, performing essentially the same function - though under slightly different criteria-that the Full Faith and Credit Clause of the United States Constitution performs with respect to judgments from sister states. ${ }^{285}$ Within the European Community, the Brussels and Lugano Conventions ${ }^{286}$ rationalize recognition of judgments among members of the European Union and the European Free Trade Area. There is no truly international civil judgment enforcement convention to which the United States is a party.

The Uniform Recognition Act applies to "any foreign judgment that is final and conclusive ${ }^{287}$ and enforceable where ren-

280. See also de la Mata, 771 F. Supp. at 1380 (explaining doctrine of comity); Restatement (Third) of Foreign Reiations, supra note 256, $\$ 481$ \& cmt: c (explaining effect of foreign judgment).

281. Restatement (Second) of Conflict of Laws $\$ 98$ (1971).

282. Id. $\$ 98 \mathrm{cmt}$. b.

283. Id. $\S 100 \mathrm{cmt}$. d.

284. Id. $\S 102 \mathrm{cmt}$. g.

285. Full faith and credit requires that, absent a violation of due process, states must respect judgments from sister states as if they were their own. See Parsons Steel, Inc. v. First Alabama Bank, 474 U.S. 518 (1986) (construing Full Faith and Credit Act, 28 U.S.C. \$ 1738); Marrese v. American Academy of Orthopaedic Surgeons, 470 U.S. 373 (1985) (same); Migra v. Warren City Sch. Dist. Bd. of Educ., 465 U.S. 75 (1984) (same).

286. Brussels Convention on Jurisdiction and Enforcement of Judgments in Civil and Commercial Matters, Sept. 27, 1968, 1968 O.J. (L 299) 32, reprinted in 29 I.L.M. 1413 (1990) [hereinafter Brussels Convention]; Lugano Convention on Jurisdiction and Enforcement of Judgments in Civil and Commercial Matters, Sept. $16,1988,1988$ O.J. (L 319) 1, reprinted in 28 I.L.M. 620 (1989) [hereinafter Lugano Convention].

287. Cerezo v. Babson Bros. Co., No. 91 C 7622, 1992 WL 18875 (N.D. Ill. Jan. 24,1992 ) (holding that prejudgment attachment issued by Spanish court not entitled to recognition under Illinois Uniform Recognition Act because not final and conclusive, and no notice to defendant). 
dered even though an appeal therefrom is pending or it is subject to appeal." ${ }^{888}$ Foreign judgment is defined as "any judgment of a foreign state granting or denying recovery of a sum of money, other than a judgment for taxes, a fine or other penalty, or a judgment for support in matrimonial or family matters. ${ }^{n 289}$ Foreign state is defined as any governmental unit other than the federal government, a state or a U.S. possession. ${ }^{290}$ The heart of the Act grants full faith and credit status to a foreign judgment "to the extent that it grants or denies recovery of a sum of money,"291 subject to certain exceptions. The judgment is deprived of its status as a judgment if:

(1) the judgment was rendered under a system which does not provide impartial tribunals or procedures compatible with the requirements of due process of law;

(2) the foreign court did not have personal jurisdiction over the defendant; or

(3) the foreign court did not have jurisdiction over the subject matter. ${ }^{292}$

Other exceptions support discretionary nonrecognition:

(1) the defendant in the proceedings in the foreign court did not receive notice of the proceedings in sufficient time to enable him to defend;

(2) the judgment was obtained by fraud;

(3) the [cause of action or a claim for relief] on which the judgment is based is repugnant to the public policy of this state;

(4) the judgment conflicts with another final and conclusive judgment;

(5) the proceeding in the foreign court was contrary to an agreement between the parties under which the dispute in question was to be settled otherwise than by proceedings in that court; or

(6) in the case of jurisdiction based only on personal service, the foreign court was a seriously inconvenient forum for the trial of the action. ${ }^{293}$

Ground (5) above permits nonrecognition of a judgment resulting

288. UNIFORM RECOGNITION ACT, supra note $275, \S 2$.

289. Id. $\S 1$ (2) (emphasis added).

290. Id. § 1(1).

291. Id. $\$ 3$.

292. Id. § 4(a).

293. Id. § $4(\mathrm{~b})$. 
from litigation evading an agreement to arbitrate. With the exception of that ground, the bases for nonrecognition under the Uniform Recognition Act are essentially the same as the bases for nonrecognition under the doctrine of comity. ${ }^{294}$

The European Community, which lacks an explicit full faith and credit clause in its constitutional documents, does have the Brussels Convention, ${ }^{295}$ a multilateral European treaty that "in effect, combines a long-arm statute with a full faith and credit clause ... [while suppressing] the use of such exorbitant national idiosyncrasies as British and Irish tag practices and the asset-based jurisdiction of various other countries against Common Market domiciliaries."296 The Brussels Convention, like the Lugano Convention, provides for recognition without any special procedures such as the Deibazione in Italy, or the Exequatur in France, Belgium and Luxembourg. A judgment supported by personal jurisdiction is entitled to recognition, which means it has the same authority and effect as in the state of origin. Moreover, it is entitled to res judicata effect. ${ }^{297}$ The enforcement procedure involves registering the judgment and is intended to be expeditious and of an ex parte nature. ${ }^{298}$

The United States has found it difficult to negotiate judgment recognition treaties with other countries. Such efforts so far have failed with the United Kingdom because of British reluctance to enforce large American jury verdicts in products liability and antitrust cases and the difficulty of accommodating international practice to the particulars of American constitutional personal jurisdiction limitations. ${ }^{299}$ Nevertheless, the Organization of American States succeeded in negotiating a treaty covering enforcement of support obligations. ${ }^{300}$ Efforts continue, in particular within the

294. Guiness PLC v. Ward, 955 F.2d 875, 884 (4th Cir. 1992).

295. See Brussels Convention, supra note 286.

296. Friedreich Juenger, American Jurisdiction: A Story of Comparative Neglect, 65 U. Colo. L. REv. 1, 17-18 (1993) (citing Brussels Convention, supra note 286). The Brussels Convention concepts were extended to EFTA countries (Austria, Finland, Iceland, Norway, Sweden and Switzerland) in the Lugano Convention. Id. at 19 (citing Lugano Convention, supra note 286).

297. Paul R. Beaumont, Civil Jurisdiction in Scotland: Brussels and Lugano Conventions $\$ \S 8.9-8.10$, at $183-84$ (2d ed. 1995) (discussing recognition rules (citing Case 42/76, DeWolf v. Cox, [1976] E.C.R. 1759)).

298. Id. $\S 8.44$, at 202.

299. Juenger, supra note 296, at 21-22 \& n.158 (describing difficulties and citing Peter Hay \& Robert J. Walker, The Proposed Recognition-of-Judgments Convention Betzueen the United States and the United Kingdom, 11 TEX. INT'L L.J. 421, 452-59 (1976) (providing text of proposed draft)).

300. Id. at 22 n.159 (citing Fourth Inter-American Specialized Conference on 
Hague Conference on Private International Law, to work out a multilateral treaty on jurisdiction and judgment recognition..$^{301}$

Regardless of the path to recognition, the effect and scope of a judgment afforded recognition is determined by concepts of preclusion under the law of the rendering state. Thus, discrete decisions on issues of fact or law may have collateral estoppel effect, depending on the rules of issue preclusion of the rendering state. Transactionally related claims that might have been brought in the foreign lawsuit may be foreclosed by res judicata, depending on the claim preclusion rules of the rendering state. ${ }^{302}$

If the foreign judgment is recognized, then it must be enforced as a procedural matter. This occurs either under a state statute like the Uniform Enforcement Act or by bringing a new lawsuit in the state of enforcement on the debt represented by the recognized foreign judgment. ${ }^{303}$ The Uniform Enforcement Act allows the judgment creditor simply to file the foreign judgment with the clerk and to obtain a writ of execution. The new lawsuit approach results in a new judgment that supports a writ of execution. The Brussels Convention, binding members of the European Union, provides for summary enforcement of covered foreign judgments under procedures similar to those of the Uniform Enforcement Act. $^{304}$ Note, however, that recognition and enforcement are not two separate proceedings. Rather, recognition is a substantive decision within the enforcement proceeding. ${ }^{305}$

Another interesting judgment execution question in the GII

Private International Law in Montevideo, July 15, 1989, 29 I.L.M. 73 (1990); Carol S. Bruch, The 1989 Inter-American Convention on Support Obligations, 40 AM. J. CoмP. L. 817 (1993)).

301. Id. at 21 \& nn.152-53 (citing 57 Fed. Reg. 54,439 (1992); ABA Endorses 50-Hour Pro Bono Minimum, Opposes Statutory Removal of U.S. Judges, 61 U.S.L.W. 2482 (Feb. 16, 1993)).

302. Authority for collateral estoppel and res judicata effect of recognized judgment is determined by the preclusion law of rendering state.

303. In such a lawsuit, the plaintiff should be entitled to summary judgment based on recognition of the foreign judgment.

304. Anton \& Beaumont, supra note 57, $\S 1.28-1.30$, at 14-16 (1995) (describing Convention's summary enforcement procedures). All of the sources of law for recognizing and enforcing foreign judgments exclude injunctions and penal or criminal judgments.

305. See Don Docksteader Motors, Ltd. v. Patal Enters., Ltd., 794 S.W.2d 760, 760 (Tex. 1990) (finding constitutional entitlement to challenge recognition within judgment enforcement process and that Texas version of Uniform Recognition Act met due process requirements). If a new lawsuit is brought on the debt represented by a foreign judgment, the recognition issue would arise in the adjudication of the plaintiff's summary judgment motion. If recognition is denied, of course, the plaintiff would have to retry the merits. 
context is what assets are subject to execution. Clearly, hardware and computer programs are subject to execution. But what about software as to which the judgment debtor has only a license? And what about obligations owing to the judgment creditor? How feasible is garnishment when these obligations run from persons all over the world? When a judgment debtor has a license on software, execution could include obtaining rights to any income from the license or possibly transferring the license from the judgment debtor. Garnishment of obligations from persons around the world may not be feasible because the garnishee is not within the physical reach of execution process, and foreign garnishment would be too time consuming. Writs of garnishment against local debtors of the judgment debtor, however, would be attractive and entirely practicable. While technology simplifies the process, it is still extremely time consuming and expensive.

Property subject to attachment includes debts. ${ }^{306}$ Once a judgment has been obtained, the plaintiff can enforce the judgment against such property held by third parties as well. In the usual circumstance in which the only property within the jurisdiction is obligations under a service contract, the value of executing against such property may still be worth something to the plaintiff. For example, if the plaintiff can establish the proposition that the obligation by an Internet service provider or router to handle messages or packets sent by the defendant and judgment debtor constitutes property subject to garnishment, then the plaintiff effectively can shut off the defendant's access to the domestic market by executing against that obligation.

\section{B. Geographic Scope of Injunctions}

The ineffectiveness of territorial limitations on the law of electronic communications invites consideration of the geographic scope of an injunction. Suppose a court in jurisdiction $A$ issues a valid injunction against $C_{1}$, prohibiting certain exchanges of files through the Internet. As long as $C_{1}$ remains within the jurisdiction, its noncompliance may be punished by contempt. ${ }^{307}$ But suppose

306. Attaching property of the defendant held by a third person usually is called "garnishment."

307. The steps in civil contempt are the service of a notice of contempt, a hearing in which the court makes a factual determination whether contempt is occurring, issuance of a contempt order in which sanctions for further noncompliance are specified and reduction of the sanctions to judgment if further noncompliance occurs. The steps in criminal contempt are the issuance of a notice, the opportunity for bail if arrest occurs, a hearing at which criminal standards of proof apply and a conviction or acquittal. 
$C_{1}$ leaves the jurisdiction and violates the terms of the order elsewhere? Or suppose $C_{2}$ who has never been inside the jurisdiction cooperates with $C_{1}$ to violate the order? What power does the court issuing the injunction then have to punish either $C_{1}$ or $C_{2}$ ? The answers are clear concerning $C_{\mathrm{l}}$, at least when a federal court has issued the injunction. By being served with process and participating in the lawsuit giving rise to the injunction, $C_{1}$ is subject to the enforcement jurisdiction of the issuing court wherever $C_{1}$ goes, anywhere in the world. ${ }^{308}$

The second question is whether $C_{2}$ can be punished: can a nonparty to the original proceeding who remains outside the district in which the injunction is issued nevertheless be punished by contempt for aiding and abetting a named party in violating the injunction? The United States Court of Appeals for the Fifth Circuit answered this question in the affirmative in Waffenschmidt $v$. MacKay, ${ }^{309}$ a securities fraud case. The district court issued a TRO and a preliminary injunction against MacKay, ordering him not to transfer the proceeds of an alleged security fraud. ${ }^{310}$ MacKay nevertheless transferred money to three persons in Texas. ${ }^{311}$ MacKay, as well as the court issuing the injunction, were located in the northern district of Mississippi. ${ }^{312}$ When the Texas actors were confronted with contempt orders, they challenged the jurisdiction of the district court. ${ }^{313}$

The district court held, and the court of appeals agreed, that the mandate of an injunction issued by a federal court runs nation-

308. Leman v. Krentler-Arnold Hinge Last Co., 284 U.S. 448 (1932) (reversing court of appeals and reinstating contempt order of district court against defendant in patent infringement suit who violated Massachusetts injunction in Michigan after participating in lawsuit in Massachusetts). "The decree ... bound the respondent personally. It was a decree which operated continuously and perpetually upon the respondent in relation to the prohibited conduct. The decree was binding upon the respondent, not simply within the District of Massachusetts, but throughout the United States." Id. at 451; see also Phelps v. McDonald, 99 U.S. 298, 308 (1878) (stating that when "necessary parties are before a court of equity, it is immaterial that res of the controversy ... is beyond the territorial jurisdiction of the tribunal"); French v. Hay, 89 U.S. (22 Wall.) 231 (1874) (holding that court with in personam jurisdiction has power to require defendants to act outside limits of territorial jurisdiction); Ernest J. Messner, The Jurisdiction of a Court of Equity over Persons to Compel the Doing of Acts Outside the Territorial Limits of the State, 14 MINN. L. Rev. 494, 514-29 (1930) (citing cases and other authority). But see People v. Central R.R., 42 N.Y. 283 (1870) (holding that New York court lacks jurisdiction to order abatement of nuisance in New Jersey).

309. 763 F.2d 711 (5th Cir. 1985), cert. denied, 474 U.S. 1056 (1986).

310. Id. at 714 .

311. Id.

312. $I d$.

313. Id. at 715 . 
wide, ${ }^{314}$ and that enforcement through a contempt proceeding must occur in the issuing jurisdiction "because contempt is an affront to the court issuing the order."315 The issuing court may "therefore hold an enjoined party in contempt, regardless of the state in which the person violates the court's orders." 116 Further, the court concluded that an injunction binds not only the parties named therein but also nonparties who act with the enjoined party, ${ }^{317}$ and therefore, "[ $\left.t\right]$ he nationwide scope of an injunction carries with it the concomitant [nationwide] power of the court to reach out to nonparties who knowingly violate its orders." 318 The court of appeals thought defendant MacKay's actions a paradigm of how a named defendant can enlist the assistance of out of state persons to frustrate an injunction. ${ }^{319}$ The court also found no problem with personal jurisdiction, concluding first that the acts of aiding and abetting placed the actors within the personal jurisdiction of the district court. ${ }^{320}$ The due process requirements of International Shoe ${ }^{321}$ were not violated because a district court has inherent power to enforce its orders, and the purposeful contacts requirements of International Shoe and World-Wide Volkswagen ${ }^{322}$ were satisfied by the intentional assistance given the named enjoined party. ${ }^{323}$

That left the problem of service with process under Federal Rule of Civil Procedure 4, as it then existed. Because former Rules 4(e) and 4(f) allowed extraterritorial service of process when permitted by state law, and Mississippi allowed service on nonresidents committing acts outside the state with foreseeable effects resulting within the state, service of the injunction on the Texas actors was permissible. ${ }^{324}$ Subsequently, the Federal Rules were amended to add Rule 4.1:

An order of civil commitment of a person held to be in

314. Id. at 716 .

315. Id.

316. Id. (citing Leman v. Krentler-Arnold Hinge Last Co., 284 U.S. 448, 454 (1932)). This is the circumstance of defendant $C_{1}$ in the textual hypothetical above.

317. Id. at 717; see Fed R. CIv. P. 65(d).

318. Waffenschmidt, 763 F.2d at 717 (citing Ex parte Lennon, 166 U.S. 548, 555

(1897); Alemite Mfg. Corp. v. Staff, 42 F.2d 832 (2d Cir. 1930)).

319. Id. at 717-18.

320. Id. at 718 .

321. International Shoe Co. v. Washington, 326 U.S. 310 (1945).

322. World-Wide Volkswagen Corp. v. Woodson, 444 U.S. 286 (1980).

323. Waffenschmidt, 763 F.2d at 722-23.

324. Id. at 720. 
contempt of a decree or injunction issued to enforce the laws of the United States may be served and enforced in any district. Other orders in civil contempt proceedings shall be served in the state in which the court issuing the order to be enforced is located or elsewhere within the United States if not more than 100 miles from the place at which the order to be enforced was issued. ${ }^{325}$

The Advisory Committee notes make it clear that nationwide service of contempt papers is contemplated only when the injunction enforces federal law. ${ }^{326}$ For injunctions that enforce state law, the more limited 100 mile rule applies. ${ }^{327}$ Rule 4.1 was intended to conform civil contempt service to the service permissible for criminal contempt because 28 U.S.C. $\$ 3041$ permits criminal contempt enforcement against a contemnor wherever the contemnor may be found. ${ }^{328}$ Thus, service of contempt papers from federal court no longer depends on state service of process rules unless it is state law that is being enforced.

It is important to recognize, however, that the rationale of Waffenschmidt extends only to nonparties who knowingly aid and abet a named enjoined party. The court of appeals extensively reviewed the evidence supporting knowledge and complicity on the part of the Texas actors. ${ }^{329}$ Moreover, a federal court lacks the power to enforce an injunction against an out-of-district person who is not subjected to the personal jurisdiction of the court. Thus, a plaintiff in Massachusetts could not enforce an injunction against someone in Sweden simply by naming the Swedish party in a complaint and the injunction without ever bothering to obtain personal jurisdiction over the Swedish party. An issuing court does not automatically acquire personal jurisdiction over anyone who may be helpful to the enforcement of the injunction.

For example, in Lynch v. Rank, ${ }^{330}$ the district court distinguished Waffenschmidt and held that it did not have personal jurisdiction over an Oregon welfare official sufficient to hold him in contempt for failing to effectuate an injunction issued in a nationwide class action relating to Social Security benefits. ${ }^{331}$ The district

325. FED. R. Crv. P. 4.1(b).

326. FED. R. Crv. P. 4.1 advisory committee's notes.

327. Id.

328. Id.

329. See Waffenschmidt, 763 F.2d at 723-27.

330. 639 F. Supp. 69 (N.D. Cal. 1985).

331. Id. at 74-76. 
court quoted Judge Learned Hand for the general rule: " $[N]$ o court can make a decree which will bind any one but a party; a court of equity is as much so limited as a court of law; it cannot lawfully enjoin the world at large, no matter how broadly it words its decree." 382 The district court found the Oregon official outside its personal jurisdiction based on the minimum contacts framework of International Shoe because the Oregon official lacked the commonality of incentives and motivations with the named defendants necessary to find that they were acting in concert or participating with each other. ${ }^{333}$ It thought the facts of Waffenschmidt, showing a common scheme to launder illegally obtained proceeds, entirely distinct. ${ }^{334}$

Another district court aligned itself with Waffenschmidt and distinguished Lynch, finding that a bank in Luxembourg could be held in contempt for releasing funds within the scope of an earlier-issued injunction. ${ }^{385}$ The court noted that " $[t]$ he basis of personal jurisdiction, if it exists, evolves out of the allegations that make out the contempt." ${ }^{336}$ The court of appeals reversed. ${ }^{337}$ It accepted the district court's analytical framework, applying the specific jurisdiction branch of the International Shoe tests for personal jurisdiction. ${ }^{398}$ It found, however, that the district court's reliance on Waffenschmidt was misplaced, because Waffenschmidt logically built on the nationwide jurisdiction of federal courts. ${ }^{339}$ It thought that the analysis "begins to crumble when a district court seeks to reach out across the Atlantic in an attempt to impose conflicting duties on another country's nationals within its own borders." 340 Because the TRO had not been registered in Luxembourg-apparently because the Luxembourg courts thought that it did not qualify as a judgment or as a claim that was certain and due-it was not an enforceable order in Luxembourg. ${ }^{341}$ Thus, conduct by the Lux1930)).

332. Id. at 72 (quoting Alemite Mfg. Corp. v. Staff, 42 F.2d 832 (2d Cir.

333. Id. at 71-72.

334. Id. at 74 (distinguishing facts of Waffenschmidt, $763 \mathrm{~F} .2 \mathrm{~d}$ at 711).

335. Reebok Int'l, Ltd. v. McLaughlin, 827 F. Supp. 622 (S.D. Cal. 1993), rev'd, 49 F.3d 1387 (9th Cir.), cert. denied, 116 S. Ct. 276 (1995).

336. Id. at 624 n.1.

337. Reebok Int'l Ltd. v. McLaughlin, 49 F.3d 1387 (9th Cir.), cert. denied, 116 S. Ct. 276 (1995).

338. Id. at 1391-92.

339. Id.

340. Id. at 1392 (citing Restatement (Third) of Foreign Relations $\S 441(1)(a)(1987))$.

341. Id. 
embourg Bank inconsistent with the terms of the order could not be contempt. Because it had not engaged in contempt, it could not be said that it purposefully directed its activities toward the United States. ${ }^{342}$ From a policy perspective, the court of appeals reasoned, "we do not agree that when a national of a foreign country follows the law of that country in that country it can be dragged half way around the world to answer contempt charges arising out of a foreign court's ineffective order." ${ }^{433}$

The reasoning of Waffenschmidt remains intact for enforcement of injunctions throughout the United States: conscious aiding and abetting can constitute the purposeful contact with the forum state necessary to satisfy the requirements of International Shoe. The Ninth Circuit, Reebok opinion also leaves open the possibility that if an American injunction is appropriately registered in a foreign country or otherwise attains legal status in that country, violation of that injunction might create personal jurisdiction in the American court issuing the injunction under the theory of Waffenschmidt. The problem in Reebok was that the injunction never attained that status in the foreign country. On the other hand, when persons are already parties, when TROs are issued ex parte, or when persons are expected to act in concert with parties, what counts is notice and not the formalities of service. ${ }^{344}$

In the international context, the same principles apply. A person originally within the personal jurisdiction of the issuing court is bound by an injunction wherever in the world he or she may go. A person not originally within the personal jurisdiction of the court or not named as a party and served with process may fall within the

342. Id. at 1394.

343. Id. at 1393.

344. See United States v. Hochschild, 977 F.2d 208, 212 (6th Cir. 1992) (stating that actual notice avoids need for formal service of process for civil contempt, acknowledging I.A.M. Nat'l Pension Fund v. Wakefield Indus., Inc., 699 F.2d 1254, 1260 (D.C. Cir. 1983) (mail service of contempt motion on nonparty insufficient)), cert. denied, 506 U.S. 1067, (1993); Securities and Exchange Comm'n v. Current Fin. Serv., Inc., 798 F. Supp. 802, 806 n.11 (D.D.C. 1992) (stating that notice to parties is presumed; however, notice, but not formal service, on nonparties must be proven). Contra FED. R. Cv. P. 4.1 advisory committee's notes (service of process not required to notify party of decree, injunction or show cause order for contempt); Environmental Defense Fund, Inc. v. EPA, 485 F.2d 780, 784 (D.C. Cir. 1973) (nonparties with actual notice bound by temporary restraining order even though not formally served); Select Creations, Inc. v. Paliafito Am., Inc., 852 F. Supp. 740, 778-80 (E.D. Wis. 1994) (reviewing Reebok and other earlier cases and holding that nonparty may be subjected to contempt as aider or abettor only when that party has notice of injunction and notice that acting in concert with certain persons would subject party to contempt proceedings, but need not have formal service; evidence showed lack of notice, thus no contempt permissible because jurisdiction lacking). 
personal jurisdiction of a court issuing an injunction by aiding and abetting a named party's violation of an injunction. The difficulty in both of these situations would be the practical enforcement of the injunction extraterritorially. Judgment recognition statutes generally exclude equitable remedies, ${ }^{345}$ and thus, it is unlikely that a foreign jurisdiction would make its courts and judicial officers available to enforce an American injunction. Thus, incarceration is not likely to be available as a contempt penalty. Nevertheless, monetary penalties could be enforced against assets of the contemnor located in the United States. In addition, civil contempt penalties could be reduced to judgment in the United States. Then, the resulting money judgment could be subject to recognition and enforcement in other countries that recognize American money judgments, although the moving party likely would be confronted with an argument that such a judgment represents a penal sanction, and thus, is outside the scope of both treaty-based and comitybased international judgment recognition.

The scope of electronic networks potentially increases the effect of injunctions. For example, suppose one participant in a network was ordered by a court to disclose everything in the network, as might occur in a discovery order to compel, with respect to a network used for trial preparation purposes. As long as the person subject to the order had access to the covered information, the entire network contents would be subject to the court's order, even though the court had jurisdiction over only a small part of the network. On the other hand, if the network administrator, beyond the personal jurisdiction of the court, were to cut off the person subject to the order, there would be little the court could do to enforce its order.

\section{Post-Conviction Extradition}

As discussed above, a civil judgment entered by a court with long arm jurisdiction is of little practical value unless it is recognized by a foreign jurisdiction or unless the defendant has assets in the judgment-rendering state. Likewise, a criminal judgment is of little value unless the defendant has property in the rendering state subject to forfeiture or unless the person of the defendant can be apprehended.

Post-conviction extradition is the criminal equivalent of transnational enforcement of a civil judgment. The legal framework for

345. For a further discussion of foreign judgment recognition, see supra notes 287-94 and accompanying text. 
post-conviction extradition is essentially the same as that for pretrial extradition, ${ }^{346}$ except that the issue of probable cause is virtually always satisfied by proof of the conviction in the requesting state. Other policy-based defenses to extradition, such as the prospect of mistreatment in the requesting state, are potentially at issue in connection with the conditions of incarceration, corresponding to the possibility of pre-trial mistreatment or mistreatment at trial in the pre-trial context. ${ }^{347}$ On the other hand, the Nevada Supreme Court has suggested that an allegation that a defendant was convicted in absentia is not necessarily enough to vitiate extradition. ${ }^{348}$

\section{Forfeiture as Criminal Penalty}

Civil forfeiture is a potential penalty for criminal conduct. ${ }^{349}$ In the absence of other procedural instructions, federal law provides for enforcement of a forfeiture in an in rem civil action. ${ }^{350}$ Other statutes authorize judges to forfeit property in a summary manner upon criminal conviction of the owner of the property. ${ }^{351}$ Under this statutory scheme, forfeiture is summarily imposed by the court as a penalty following a jury verdict of guilt in a criminal case. Such summary proceedings should be limited to situations in which it is obvious that the target property is owned by the defendant and that the jury's guilty verdict negates any possible defense to the for-

346. For a further discussion of pre-trial extradition, see supra notes 164-78 and accompanying text.

347. See In re Requested Extradition of Smyth, 61 F.3d 711, 720 (9th Cir. 1995) (explaining terms of treaty amendment with Great Britain); Beukes v. Pizzi, 888 F. Supp. 465, 467 (E.D.N.Y. 1995) (stating that question in post-conviction extradition is only " whether the appellant's alleged offense fell within the terms of an extradition treaty and whether an official with jurisdiction was presented with sufficient evidence to warrant a finding that there was a reasonable ground to believe that the appellate was guilty' " and that probable cause can be established by adjudication of guilt by court in requesting country (quoting Ahmad v. Wigen, 910 F.2d 1063, 1064 (2d Cir. 1990))).

348. See Castriotta v. State, 888 P.2d 927, 929 (Nev.) (indicating that, in general, constitutional defenses must be considered by requesting state, not by requested state, in reviewing request for writ of extradition), cert. denied, $116 \mathrm{~S}$. Ct. 54 (1995).

349. But cf. Austin v. United States, 509 U.S. 602 (1993) (civil forfeiture for drug offense subject to Eighth Amendment excessive fines limitation); Alexander v. United States, 509 U.S. 544 (1993) (holding that forfeiture of assets used in entertainment business did not violate First Amendment and that lower court should have determined whether forfeiture was "excessive fine" in violation of Eighth Amendment); United States v. 92 Buena Vista Ave., 507 U.S. 111 (1993) (interpreting forfeiture provision of the Comprehensive Drug Abuse Prevention Act of 1970,21 U.S.C. $\$ 881(a)$, (b) (1988) and limiting forfeiture of property owned by one other than criminal defendant).

350. 28 U.S.C. $\$ 2461$ (1994).

351. 18 U.S.C. $\S 982$ (1994). 
feiture as a matter of logic. ${ }^{352}$ Generally, property can be forfeited only if it constitutes the contraband "per se," such as heroin, cocaine or marijuana, or if it constitutes "derivative contraband"-articles used in connection with the violation of a statute that provides for their forfeiture. ${ }^{353}$ Typically, derivative forfeiture is limited to property that "facilitates" the commission of a crime..$^{354}$

In the GII context, these statutes potentially are sources of authority for forfeiture of facilities used in digital communications supporting crimes. ${ }^{355}$ While it is tempting to compare criminal forfeiture with in rem jurisdiction in civil procedure, there is an important difference. A fully effective civil judgment can be obtained based on in rem jurisdiction, with or without service of process under long arm statutes. Conversely, criminal forfeiture is not permissible without a valid conviction, and one may not be convicted of a crime in absentia.

\section{DiscoverY}

Important aspects of pre-trial investigation in both the civil and criminal contexts involve the assertion of judicial power. Civil discovery obligates parties to civil litigation to disclose documents and

352. Asset Forferture Office, Criminal Division, U.S. Dep't of Justice, AsSET Forfeiture: Compilation of Civil Statures 4-5 (1987) [hereinafter DOJ Compilation] (citing 16 U.S.C. $\$ 690($ e) (1982)).

353. Id. at 7-11 (citing King v. United States, 364 F.2d 235 (5th Cir. 1966) (concluding Kennedy assassination rifle not forfeitable)).

354. See id. at 13-19 (discussing meaning of "facilitate").

355. See 15 U.S.C. $\$ 6$ (1994) (forfeiture of property transported in interstate commerce subject to conspiracy violating Sherman Act $\$ 1,15$ U.S.C. $\$ 1$ (1994)); 17 U.S.C. $\$ \S 506$ (b), 509(a) (1994) (forfeiture of implements, devices or equipment used in manufacture of copies or phonorecords that infringe copyright); 17 U.S.C. $\$ 603(c)$ (1994) (forfeiture of imported items infringing copyright); 18 U.S.C. $\$ 492$ (1994) (forfeiture of any article, device or other thing used for forgery and counterfeiting); 18 U.S.C. $\$ 545$ (1994) (forfeiture of "merchandise" imported without compliance with custom's laws); 18 U.S.C. $\$ 981$ (a)(1)(A) (1994) (forfeiture of proceeds of money laundering); 18 U.S.C. $\$ 2254(a)(1)-(2)$ (1994) (forfeiture of material or equipment used in producing, reproducing, transporting, shipping or receiving any child pornography); 18 U.S.C. $\$ 2318$ (d) (1994) (forfeiture of articles to which counterfeit labels are affixed); 18 U.S.C. § 2513 (1994) (forfeiture of devices used to violate 18 U.S.C. $\$ 2511$ (1994) (prohibiting wiretapping)); 19 U.S.C. $\$ 1526$ (b) (1994) (forfeiture of merchandise of foreign manufacture with infringing trademark); 19 U.S.C. \$ 1595(a) (1994) (allowing law enforcement officials to seek warrant to search for and to seize property subject to forfeiture); 21 U.S.C. $\$ 881$ (a) (1994) (forfeiture of controlled substances and equipment, materials or property used for production or conveyance of controlled substances); 22 U.S.C. $\$ 401$ (a) (1994) (forfeiture of "vessel, vehicle or aircraft" used to effect illegal exportation of munitions); 31 U.S.C. $\$ 5317$ (c) (1994) (forfeiture of proceeds of illegal monetary imports and exports); 47 U.S.C. $\$ 510$ (1994) (forfeiture of device or component used for radio transmissions without compliance with FCC requirements). 
to permit access to their facilities, and obligates anyone, party or not, to submit to sworn depositions. Criminal search and seizure obligates the subjects of criminal investigations as well as third parties to submit to governmental search and seizure. There are important territorial limitations on the reach of both investigatory techniques. Because the likelihood that the evidence will be located in a state or country different from where a matter is being litigated, and the GII controversies that will follow, an appreciation of these territorial limits on investigation is important.

\section{A. Civil Discovery}

One of the most important differences between American and foreign law relates to the methods of obtaining evidence. The Federal Rules of Civil Procedure permit broad discovery generally under the control of the parties. ${ }^{356}$ While few foreign civil procedure systems, even those in the civil law tradition, deny discovery altogether, they often permit it only under the direct supervision of a judicial officer. ${ }^{357}$ "[T] he taking of evidence in a civil law country," under the Federal Rules, "may constitute the performance of a public judicial act by an unauthorized foreign person." 358 The Federal Rules approach is fundamentally inconsistent with the inquisitorial character of the civil law system under which "the judge normally questions the witness and prepares a written summary of the evidence." 359

When discovery is limited, pleadings are much more elaborate, including evidence and legal theories and logic or evidence sup-

356. FED. R. Crv. P. 26.

357. Civil law views discovery as an integral part of the trial process to be supervised by a judicial officer. Discovery at the initiative and under the control of counsel for private litigants is antithetical. Also, verbatim transcripts are an American tradition, not a civil law one. Even in England, clearly a common-law country, interrogatories are limited, depositions are relatively rare, and discovery of nonparties is difficult. See Société Nationale Industrielle Aérospatiale v. United States Dist. Court, 482 U.S. 522, 561 n.18 (1987) (Blackmun, J., concurring in part and dissenting in part) (describing differences in procedure) (citing S. SEIDEL, ExTRA-

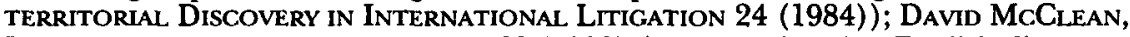
INTERNATIONAL JUdicial AsSistance 60 (1992) (commenting that English discovery is limited to those who are parties); id. at 61 (stating that English discovery is limited to discovery of documents; interrogatories are little used and there is no equivalent of depositions). But see Hans Smit, Dispute Resolution in Europe: A Comparative Context for the Resolution of Disputes Between Americans and Canadians, 17 CANADA-U.S. L.J. 281, 288 (1991) (explaining certain European methods of discovery and arguing that they are effective).

358. Aérospatiale, 482 U.S. at 557 (Blackmun, J., concurring in part and dissenting in part).

359. Id. at 560 (Blackmun, J., concurring in part and dissenting in part). 
porting denials. ${ }^{360}$ Additionally, the absence of discovery is usually offset by some other method; in France, for example, the courts use an expertise, a report by an expert on the case, based on information drawn from any relevant source. ${ }^{\mathbf{3 6 1}}$

Historically, U.S. litigants sought discovery abroad either under the Federal Rules against persons who were subject to personal jurisdiction of the court or through letters rogatory. The Inter-American Convention on Letters Rogatory ${ }^{362}$ provides that letters rogatory shall be executed in accordance, with the laws and procedural rules of the state of destination. ${ }^{363}$ Federal Rule 28(b) specifically provides for the taking of depositions in foreign countries either before a person authorized to administer oaths under foreign law or under American law, before a person commissioned by the court or pursuant to a letter rogatory. ${ }^{364}$ Thus, a corporate party with practical control over materials owned by one of its corporate affiliates may be compelled to produce them, even though the materials are located in a foreign country. ${ }^{365}$

In the past, the letters rogatory procedure was disfavored because foreign courts were under no obligation to execute them. Today, discovery in foreign countries is facilitated by the Federal Rules of Civil Procedure ${ }^{366}$ and the Hague Convention on the Taking of Evidence Abroad in Civil or Commercial Matters (the "Hague Evidence Convention"). ${ }^{367}$ The Hague Evidence Conven-

360. Smit, supra note 357, at 288.

361. Id. at 289.

362. Inter-American Convention on Letters Rogatory, Jan. 30, 1975, art. 5, 14 I.L.M. 339, 340.

363. The Inter-American Convention on Taking Evidence Abroad is similar in most respects to the Hague Evidence Convention. See Karl Schwappach, The InterAmerican Convention on Taking Evidence Abroad: A Functional Comparison with the Hague Convention, 4 N.Y. INT'L L. REv. 69 (1991) (comparing six dimensions of two conventions by one of drafters).

364. Fed. R. Civ. P. 28(b) (2)-(4).

365. General Envtl. Science Corp. v. Horsfall, 136 F.R.D. 130, 133-34 (N.D. Ohio 1991) (ordering corporate party to produce documents held by nonparty Swiss corporation alleged to be sham created to evade discovery).

366. FED. R. CIv. P. 28(b) (1993) (providing for taking of depositions in foreign countries); FED. R. Crv. P. 28 advisory committee's notes (1993 amendment) (explaining revision intended to make effective use of Hague Convention on the Taking of Evidence Abroad in Civil or Commercial Matters); see also FED. R. CIV. P. 28 advisory committee's notes (1963 amendment) (noting hostility of some foreign countries to depositions pursuant to private request).

367. Hague Convention on the Taking of Evidence Abroad in Civil or Commercial Matters, opened for signature, Mar. 18, 1970, 23 U.S.T. 2555, 847 U.N.T.S. 231 [hereinafter Hague Convention]. The states that are currently parties to the Hague Convention include: Argentina, Australia, Barbados, Cyprus, Czech Republic, Denmark, Finland, France, Federal Republic of Germany, Israel, Italy, Luxembourg, Mexico, Monaco, Netherlands, Norway, Portugal, Singapore, Slovak 
tion was developed at U.S. initiative and adopted in 1972.368 The Convention responded to the practice of some countries of insisting on "the exclusive use of the complicated, dilatory and expensive system of letters rogatory or letters of request. ${ }^{369}$ Others refused judicial assistance because of the absence of a treaty or convention. ${ }^{370}$ The most typical practice was for civil law countries to use "commissioned rogatories," resulting in "a resume of the evidence prepared by an executing judge and signed by the witness, while the common law technique results normally in a verbatim transcript of the witnesses' testimony certified by the reporter." 371

The Convention was intended: (1) to make letters of request the principal means of obtaining evidence abroad, (2) to increase the powers of consuls while limiting the use of a Commissioner, (3) to provide for securing evidence in the form needed by the court hearing the action and (4) to preserve more favorable practices arising from internal law. ${ }^{372}$ The advantage offered by the Convention's letter of request procedure was that it offered a "mechanism for compelling discovery from reluctant witnesses." 373 The Convention also obligates member states to fulfill properly completed letters of request. ${ }^{374}$ Under the Convention, practices have changed

Republic, Spain, Sweden, United Kingdom and United States. Martindale-Hubbell International Law Digest IC-18 (1995). The Hague Convention has not been adopted by Canada. Smit, supra note 357, at 286.

368. Société Nationale Industrielle Aérospatiale v. United States Dist. Court, 482 U.S. 522, 530 (1987) (citing 118 Cong. REc. 20,623 (1972)).

369. Id. at 531 (quoting Secretary of State's letter of submittal of Hague Convention to President).

370. Id.

371. Id. at 531-32.

372. Id. at 532 .

373. Gary B. Born \& Scott Hoing, Comity and the Lower Courts: Post-Aérospatiale Applications of the Hague Evidence Convention, 24 INT'L LAW. 393, 397 (1990) (citing Hague Convention, supra note 367) (referring to article 10 requirement of Hague Convention that requested state apply appropriate measures of compulsion to same extent that internal law provides). The Convention's letter of request procedure is superior to the letter rogatory procedure in three ways:

First, the Evidence Convention requires signatories to designate a Central Authority to receive requests; this simplifies determining to whom the request should be addressed and shortens execution time. Second, the Letter of Request is mandatory in a ratifying state, except where it would threaten the state's sovereignty or security .... Finally, the requesting court may specify procedures compatible with its own law not otherwise available in the executing state.

Thomas J. Tallerico \& Jan L. Harrick, Discovery of Witnesses and Documents Located Abroad, 69 Mich. B.J. 664, 666 (1990) (citing Hague Convention, supra note 367, arts. 2, $12 \& 9$ ).

374. Born \& Hoing, supra note 373, at 397. 
to facilitate discovery, ${ }^{375}$ although enactment of "blocking statutes" mitigates the improvements. ${ }^{376}$

In Société Nationale Industrielle Aérospatiale v. United States District Court, ${ }^{377}$ the Supreme Court rejected the argument that the Hague Evidence Convention is the exclusive procedure for discovery on foreign soil, ${ }^{378}$ prompting the recent revisions in the Federal Rules. A 1990 survey of lower court applications of Aérospatiale concluded that "lower courts have found the Aérospatiale comity analysis cumbersome and unhelpful and have almost uniformly refused to order extraterritorial discovery pursuant to the Hague Evidence Convention." ${ }^{379}$ This conclusion was based on the review of ten published decisions. ${ }^{380}$ The review identified four aspects that are troublesome: first, the lack of workable guidelines; second, the imposition of the burden of proof on the proponent of Convention use; third, the refusal to require first resort to the Convention; and fourth, the virtual unavailability of appellate review because of the broad discretion enjoyed by district judges. ${ }^{881}$ In addition, lower federal courts generally have not required use of the Convention procedures, even when the discovery sought relates to the establishment of personal jurisdiction. ${ }^{382}$ Typically, state courts also have followed the Aérospatiale formula. ${ }^{383}$

375. The Hague Convention itself requires the availability of methods to compel attendance of witnesses, oaths, verbatim transcripts and examination by counsel for both sides. Aérospatiale, 482 U.S. at 561 (Blackmun, J., dissenting). France, among other nations, has enacted legislation making these procedures available. Id. (Blackmun, J., dissenting) (citing N.C.P.C., arts. 736-48 (76th ed. Dalloz 1984)).

376. See id. at 526 (noting that French "blocking statute" prevented party from responding to discovery requests that did not comply with Hague Convention). A blocking statute forbids discovery and imposes penalties for permitting it. The French blocking statute provides:

Subject to treaties or international agreements and applicable laws and regulations, it is prohibited for any party to request, seek or disclose, in writing, orally or otherwise, economic, commercial, industrial, financial or technical documents or information leading to the constitution of evidence with a view to foreign judicial or administrative proceedings or in connection therewith.

Id. at 526 n.6 (quoting French Penal Code, C. PEN., No. 80-538, art. 1A).

377. 482 U.S. 522 (1987).

378. Id. at 529 .

379. Born \& Hoing, supra note 373 , at 394 .

380. Id. at 401 .

381. Id. at 401-03.

382. $I d$. at 405-06 (citing Insurance Corp. v. Compagnie des Bauxites de Guinée, 456 U.S. 694 (1982); In re Sealed Case, 832 F.2d 1268, 1274 (D.C. Cir. 1987); In re Marc Rich \& Co., A.G., 707 F.2d 663, 670 (2d Cir.), cert. denied, 463 U.S. 1215 (1983); Rich v. KIS California, Inc., 121 F.R.D. 254, 258-60 (M.D.N.C. 1988)). 383. Id. at $406 \mathrm{n.71}$ (citing Scarminach v. Goldwell GmbH, 531 N.Y.S.2d 188, 
The 1993 amendments to Federal Rule of Civil Procedure 28(b) require treaty or convention procedures to be used if feasible for the taking of a deposition. ${ }^{384}$ This requirement would apply even if a verbatim transcript is not available, or testimony cannot be taken under oath. ${ }^{885}$ The Manual for Complex Litigation ${ }^{886}$ suggests that formal discovery be taken abroad only with prior approval by the court ${ }^{387}$ and suggests that the procedures of the Hague Convention be utilized if available; additionally, discovery should be limited to that actually needed for trial and not be investigatory in character or open-ended. ${ }^{388}$ In addition, the Manual suggests that the court's findings "specifying what is permitted and why it is needed, [and] should be incorporated into a separate order that can be presented to foreign authorities, even if 'letters rogatory' are not being issued." ${ }^{89}$ It also suggests a court appointed expert as a translator ${ }^{390}$ and, if necessary, the appointment of a special master to supervise the deposition personally, if that is permitted by foreign law..$^{391}$

Sometimes, the tables are turned, and a foreign party seeks dis-

190 (Sup. Ct. 1988); Sandsend Fin. Consultants v. Wood, 743 S.W.2d 364 (Tex. Ct. App. 1988)); see also David Westin \& Gary B. Born, Applying the Aérospatiale Decision in State Court Proceedings, 26 Colum. J. TRANSNAT'L L. 297 (1988) (indicating that U.S. Supreme Court in Aérospatiale did not directly address how decision affects state rules of discovery).

384. Fed. R. Crv. P. 28(b).

385. See FED. R. CIV. P. 28 advisory committee's notes (1993 amendments) (stating purpose of section (b)).

386. Manual for Complex Litigation (Second) (Fed. Judicial Ctr. ed., 1985) [hereinafter MANUAI].

387. Id. $\S 21.485,33.64$.

388. Id. § 21.485 .

389. Id. (suggesting compliance with latest edition of RESTATEMENT (SECOND)

of ForEign ReLations LAW $\$ 437$ (1965)).

390. Id. $\$ 33.64$.

391. Id. $\$ 21.485$. 
covery of an American entity. ${ }^{392}$ In re Letters Rogatory ${ }^{393}$ involved an Argentine court's issuance of letters rogatory seeking to obtain discovery of documents located in Pennsylvania and within the custody of Aydin Corporation. ${ }^{394}$ One of Aydin's bases for resisting the requested discovery was that it would force the disclosure of trade secrets. ${ }^{395}$ The district court granted a subpoena, pursuant to letters rogatory compelling the Pennsylvania non-party to make available certain documents and materials requested by the Argentine court. ${ }^{396}$ Aydin was required to deliver the requested documents to a special examiner within the Eastern District of Pennsylvania. ${ }^{397}$ In response, Aydin filed a motion to quash or to modify the subpoena. ${ }^{398}$ The court considered the text and legislative history of 28 U.S.C. $\$ 1782$ which authorizes district courts to respond to letters rogatory, and concluded that it had broad discretion to decide whether to honor the Argentine request. ${ }^{399}$ Because the trade secrets claims were based in significant part on the need for confidentiality of the documents to protect Argentine national security, the court refused to deny discovery of the material altogether. ${ }^{400}$

392. The district courts are authorized to order persons within their districts to give testimony and to produce documents pursuant to letters rogatory. 28 U.S.C. $\$ 1782$ (a) (1994). In addition to the letters rogatory procedure under section 1782(a), a letter of request may be transmitted through the State Department or through the Justice Department as Central Authority under the Hague Evidence Convention. The Rules of Civil Procedure are available for such requests. Id. Reciprocity is not a prerequisite for discovery. Walter B. Stahr, Discovery Under 28 U.S.C. \$ 1782 for Foreign and International Proceedings, 30 VA. J. INT'L L. 597, 60809 (1990) (comparing John Deere, Ltd. v. Sperry Corp., 754 F.2d 132, 135 (3d Cir. 1985 ) (rejecting contention that 28 U.S.C. $\$ 1782$ requires reciprocity before discovery order is granted) with In re Lo Ka Chun v. Lo To, 858 F.2d 1564 (11th Cir. 1988) (denying discovery on reciprocity grounds)). The U.S. Supreme Court has also held that there is no reciprocity requirement. Société Nationale Industrielle Aérospatiale v. United States Dist. Court, 482 U.S. 522, 529-30 (1987).

393. 144 F.R.D. 272 (E.D. Pa. 1992).

394. $I d$. at 273. "Aydin Corporation is a non-party to the foreign action, but the holder of the requested documents." Id.

395. Id. at 276. The Argentine litigation involved a stock fraud claim by a citizen of Argentina against directors of an Argentine company. Id. at 273-74. The basis for the claim was that the Argentine defendants had concealed their impending agreement with Aydin, which was located in the Eastern District of Pennsylvania. Id.

396. Id. at 274.

397. Id.

398. $I d$.

399. Id. (citing In re Request for Assistance, 848 F.2d 1151, 1154 (11th Cir. 1988)); see also Malev Hungarian Airlines v. United Technologies Int'l, Inc., 964 F.2d 97, 100 (2d Cir.) (reversing district court and concluding that foreign litigants entitled to U.S. discovery under 28 U.S.C. $\$ 1782$ without first seeking discovery through foreign tribunal in which case was pending), cert. denied, 506 U.S. 861 (1992).

400. In re Letters Rogotory, 144 F.R.D. at 276. 
Rather, it imposed a protective order and found that the Argentine court was the appropriate tribunal to consider risks to Argentine national security. ${ }^{401}$

Of more general significance, the court also found that the fact that the documents were available in Argentina was not a sufficient basis for quashing the subpoena under the letters rogatory. ${ }^{402} \mathrm{Be}$ cause the requesting party was obligated to compensate the producer of the documents for its expense, whether the party chose to pursue discovery abroad or in the United States was that party's litigation decision. ${ }^{403}$ The resulting advantage is that it keeps U.S. courts out of having to interpret foreign discovery procedures in order to decide whether material would be available in the foreign jurisdiction. ${ }^{404}$

There is a general choice of law rule that forum procedure is always applied, even if foreign substantive law is applied. Therefore, the discovery rules of the forum would significantly impact on the investigative techniques made available. Indeed, the expansive nature of American discovery may be one reason that litigation is drawn to American courts should plaintiffs have that option.

\section{B. Searches and Seizures of Electronic Materials}

An important part of the criminal justice process is investigation through searches and seizures. Searches and seizures of electronic materials, especially in the GII context, implicate jurisdictional issues because of the likelihood, as in all of the examples considered in this Article, that evidence of a crime would be located in a different jurisdiction from the one in which criminal prosecution occurs. ${ }^{405}$

Search and seizure powers relating to foreign instrumentalities are especially important. The Foreign Intelligence Surveillance Act of 1978 (FISA) ${ }^{406}$ regulates electronic surveillance of foreign powers and agents. FISA sets up a special court comprised of seven

401. Id. ("Further, should Aydin or the Argentine Air Force conclude that the contents of the Letters Rogatory present a threat to Argentina's national security, they should present such evidence to the Argentine Court for a modification of that court's discovery order.").

402. $I d$. at 277.

403. Id.

404. Id. (citing In re Request for Judicial Assistance, 555 F.2d 720, 723 (9th Cir. 1977)).

405. There are fewer legal obstacles to securing fugitives from abroad than for collecting evidence located abroad. See Nadelmann, supra note 163, at 814 (discussing legal obstacles to obtaining fugitives).

406. 50 U.S.C. $\S \S 1801-08$ (1994). 
district judges who hear and determine applications for electronic surveillance warrants ${ }^{407}$ under the Act. ${ }^{408}$ The statute allows warrantless electronic acquisition of communications exclusively between foreign powers not involving a substantial likelihood that the surveillance will acquire the contents of any communication to which a "United States person" is a party. Further, it permits the acquisition of technical intelligence other than the spoken communications of individuals from property or premises under the open and exclusive control of a foreign power. ${ }^{409}$ "United States person" is defined to include United States citizens, resident aliens, unincorporated associations involving substantial U.S. membership and corporations incorporated in the United States, but excludes corporations controlled by foreign governments. ${ }^{410}$

These types of surveillance are permitted only upon certification by the Attorney General, which must be filed under seal with the special court established by the Act. ${ }^{411}$ Further, these surveillances may not exceed one year in duration. ${ }^{412}$ FISA court orders are available only on application by a federal officer supported by an Attorney General finding of compliance with the criteria of the Act. ${ }^{413}$ This application must disclose the facts and circumstances justifying the applicant's belief that the target is a foreign power or agent of a foreign power, that the facilities or places at which the surveillance is directed is being used or is about to be used by a foreign power or agent of a foreign power, and must include a description of the nature of the information sought and the type of communications or activities to be subjected to the surveillance. ${ }^{414}$

407. Although the statute uses the term "court order" instead of "warrant," the two terms are synonymous. See United States v. Megahey, 553 F. Supp. 1180, 1190 (E.D.N.Y. 1982) (concluding that FISA order is warrant within meaning of Fourth Amendment), aff'd mem., 729 F.2d 1444 (2d Cir. 1983).

408. 50 U.S.C. $\S 1803$ (a) (1994). The Foreign Intelligence Surveillance Act of 1978 (FISA) also establishes a court of review, comprised of three United States district judges or circuit judges who have jurisdiction to review denial of any application made to the seven-judge court, with the possibility of certiorari review by the Supreme Court. Id. $\S 1803$ (b).

409. Id. $\$ 1802(\mathrm{a})(1)(\mathrm{A})(\mathrm{ii}),(\mathrm{a})(1)(\mathrm{B})$.

410. Id. \$ $1801(\mathrm{i})$.

411. Id. § 1802(a) (certification by Attorney General); id. § 1802(a)(3) (filing requirement).

412. Id. $\$ 1802(\mathrm{a})(1)$.

413. Id. § 1804(a); see United States v. Megahey, 553 F. Supp. 1180, 1194-95 (E.D.N.Y. 1982) (discussing. FISA requirements and procedures satisfied by surveillance order for home telephone).

414. 50 U.S.C. $\$ \S 1804$ (a) (4), (6) (1994); see United States v. Cavanagh, 807 F.2d 787, 791 (9th Cir. 1987) (stating that nature of foreign intelligence information makes it impossible to provide detailed description of nature of information 
In addition, the application must include a certification by the Assistant to the President for National Security Affairs or another executive branch official designated by the President supporting the application, including a certification that the information sought "cannot reasonably be obtained by normal investigative techniques" 415 and a statement of the proposed "minimization procedures." 416 A judge of the special report is required to issue an ex parte order upon finding that the application requirements have been satisfied. ${ }^{417}$

In emergency situations, the Attorney General may authorize the commencement of surveillance followed by an application for a court order within twenty-four hours. ${ }^{418}$ When information obtained under the Act is to be used as evidence in any judicial or administrative proceeding, the government must notify the person against whom it is to be used, and that person may move to suppress the evidence on the grounds that it was unlawfully acquired or that the surveillance producing it did not conform with an order under the statute. ${ }^{419}$

The scope of the statute is determined by its definition of "electronic surveillance," 420 which includes the nonconsensual acquisition of the contents of any wire communication within the United States by means of an electronic, mechanical or other surveillance device, ${ }^{421}$ and the intentional acquisition by the same means "of any wire or radio communication sent by or intended to be received by a particular, known United States person who is in the United States" if that person is targeted and "has a reasonable expectation of privacy and a warrant would be required for law enforcement purposes." ${ }^{422}$ Radio communications are included when both the sender and all intended recipients are located within the United States, a reasonable expectation of privacy exists and a war-

sought and holding that there is no Fourth Amendment violation from absence of detailed description of targeted information).

415. 50 U.S.C. $\S 1804$ (a)(7)(C) (1994).

416. Id. $\$ 1804(\mathrm{a})(5)$. "Minimization procedures" are defined to mean specific procedures minimizing the acquisition, retention and dissemination of nonpublic information concerning nonconsenting United States persons. Id. $\S 1801(\mathrm{~h})(1) ;$ see Megahey, 553 F. Supp. at 1195 (approving minimization).

417. 50 U.S.C. $\$ 1805$ (a) (1994).

418. Id. $\S 1805(\mathrm{e})$.

419. Id. $\S 1806$ (c)-(e); cf. United States v. Thomson, 752 F. Supp. 75, 76 (W.D.N.Y. 1990) (denying motion for disclosure of FISA information that government did not intend to use).

420. 50 U.S.C. $\$ 1801$ (f) (1994).

421. Id. § 1801 (f) (2).

422. Id. § 1801 ( $f$ )(1). 
rant would be required for law enforcement purposes. ${ }^{423}$ Monitoring by the same means "to acquire information, other than from a wire or radio communication," is covered under circumstances in which a person has a reasonable expectation of privacy and a warrant would be required for law enforcement purposes. ${ }^{424}$ This part of the definition is broad enough to include stored electronic communications and electronic communication streams as they are defined in the Electronic Communications Privacy Act (ECPA). ${ }^{425}$

The nature of the information targeted by a FISA warrant must relate to foreign intelligence and not to criminal conduct, but this subject matter requirement has been construed broadly to include almost any basic information about the nature of contacts between United States citizens and foreign powers or agents. ${ }^{426}$ Thus, there is some overlap between FISA and domestic warrants and ECPA orders, particularly for terrorist activities. ${ }^{427}$ Additionally, it is in the nature of FISA information that an FISA warrant cannot be supported solely by probable cause of criminal activity, but the absence of this element does not violate the Fourth Amendment. ${ }^{428}$ In general, the probable cause necessary to justify national security surveillance is different from that necessary for criminal investigations. ${ }^{429}$

\section{Foreign Searches for Criminal Evidence}

One of the most common electronic search and seizure problems is the one presented in the recent book, The Cuckoo's Egg. ${ }^{430}$ A computer system operator in California, victimized by an intruder, obtained from a California state court a search warrant authorizing a tap by the telephone company. The tracing of the

423. Id. $\S 1801(\mathrm{f})(3)$.

424. $I d . \$ 1801(\mathrm{f})(4)$.

425. Pub. L. No. 99-508, 100 Stat. 1848 (1986) (codified as amended in scattered sections of 18 U.S.C.).

426. See United States v. Thomson, 752 F. Supp. 75, 81 (W.D.N.Y. 1990) (rejecting argument that FISA requirements had not been met because information could not have related directly to terrorism, foreign defense or diplomatic matters).

427. United States v. Sarkissian, 841 F.2d 959, 964 (9th Cir. 1988) (finding wiretap connected with investigation of international terrorism in United States properly sought under FISA rather than Title III even though activities were criminal offenses punishable under federal law).

428. United States v. Cavanagh, 807 F.2d 787, 791 (9th Cir. 1987) (rejecting argument to suppress fruits of FISA warrant because of Fourth Amendment violation due to absence of likelihood of uncovering evidence of crime).

429. Id. at 790 (characterizing United States v. United States Dist. Court, 407 U.S. 297,322 (1972)).

430. Clifford Stoll, The Cuckoo's Egg: Tracking a Spy Through the Maze of Computer Espionage (1989). 
data communication, however, led to Virginia, and the C\&P Telephone Company in Virginia declined to disclose the necessary information to trace the call further, based on the California warrant. A warrant could not be obtained in Virginia because no crime had been committed in Virginia. Thus, the investigation of the intrusion was effectively blocked. The same problem occurred when the trail led to Germany. No crime had been committed in Germany, and the German courts would not issue compulsory process compelling the searches necessary to further the investigation. Eventually, requests under legal assistance agreements between the United States and Germany allowed the investigation to proceed.

The issue of foreign searches involving GII material is likely to grow in importance and difficulty. It is therefore appropriate to identify some alternative ways of dealing with the problem. Traditionally, coercive power to obtain evidence was purely territorial. As this Article has consistently explained, traditional American and European procedure began with the principle that criminal jurisdiction is territorial and that exercise of power by one state on the territory of another is prohibited. ${ }^{431}$ Therefore, the procedure for obtaining evidence in a foreign country involved letters rogatory, which encompassed search warrants and requests for seizure. ${ }^{432}$ The letter rogatory procedure, however, rarely is satisfactory for criminal investigations because it is slow and usually provides for advance notice and participation by opposing parties. Criminal justice authorities almost always prefer ex parte procedures contemplated by American search warrants, subpoenas and warrantless searches.

Currently, U.S. law enforcement authorities obtain evidence located in foreign countries pursuant to a variety of informal and formal techniques. The U.S. Attorneys' Manual identifies several ways of obtaining evidence located in foreign countries, including for-

431. See Dionysios D. Spinellis, A European Perspective, in 2 International Criminal Law: Procedure 351 (M. Cherif Bassiouni ed., 1986) (noting general principles of international law that prohibit exercise of judicial authority beyond jurisdiction and imposition of state's power over another state).

432. Id. at 366 (noting that European Convention provides for search and seizure in Article 5); see European Convention on Mutual Assistance in Criminal Matters, concluded Apr. 20, 1959, art. 5, 472 U.N.T.S. 185 [hereinafter European Convention] (reservation of right to make execution of letters rogatory for search or seizure of property dependent upon condition that offense motivating letter rogatory is punishable under both law of requesting party and law of requested party). The Council of Europe adopted the European Convention on April 20, 1959. On March 17, 1978, the Council adopted the Additional Protocol to the European Convention on Mutual Assitance in Criminal Matters, Europ. T.S. 99. William A. Schabas, Book Review, 5 CRIM. L.F. 137, 140 \& n.14 (1994). 
mal requests under mutual legal assistance treaties (MLATs), letters rogatory in the absence of a treaty or executive agreement, and subpoenas directed to U.S. citizens and permanent residents of the United States located abroad. ${ }^{433}$ The United States currently has MLATs with approximately seventeen countries, including Belgium, Canada, Italy, Mexico, the Netherlands, Spain, Turkey and the United Kingdom. ${ }^{434}$ In the absence of any MLAT, a U.S. law-enforcement official would resort to letters rogatory. ${ }^{435}$ As mentioned above, though, letters rogatory have serious limitations as a means of criminal investigation and discovery. Civil law systems typically will not accept letters rogatory from prosecutors because of the tradition in those systems that judges, called examining magistrates, conduct criminal investigation and discovery. Thus, letters rogatory are of little use when the requesting state is a common law jurisdiction, in which the prosecutor is in charge of investigation rather than a judicial official, and when the requested state is a civil law jurisdiction, which works in reverse. ${ }^{436}$

MLATs are therefore of greater value. Each treaty to which the U.S. is a party "contains a provision obligating a requested country to conduct searches and seizures on behalf of a requesting country if the request includes information justifying such action under the laws of the requested country." 437 Although the treaties require

433. U.S. Dep't of Justice, United States Attorneys' Manual $\$$ 9-13.521, 9-13.522, 9-13.525 (1988) [hereinafter U.S. ATTORNEYS' MANUAL].

434. Eric Bentley, Jr., Toward an International Fourth Amendment: Rethinking Searches and Seizures Abroad After Verdugo-Urquidez, 27 Vand. J. TransNat'L L. 329, $369 \mathrm{nn} .169-70$ (1994). See Consular Conventions, Extradition Treaties, and Treaties Relating to Mutual Legal Assistance in Criminal Matters (MLATS): Hearing Before the Committee on Foreign Relations, United States Senate, 102d Cong. 5 (1992) [hereinafter Senate Hearing] (testimony of Allen J. Kreczko) (enumerating mutual legal assistance treaties); id. at 10-11 (prepared statement of Robert S. Mueller, III) (supporting eight law enforcement treaties); id. at 38 (reporting questions and answers regarding status of mutual legal assistance treaties). In 1991, the Department of Justice handled about 1500 requests under the treaties, some 780 from other countries. Id. at 11-13 (prepared statement of Robert S. Mueller, III).

435. See Bentley, supra note 434, at 367-68 \& n.160 (citing U.S. ATtORNEYs' MANUAL, supra note 433, \$ 9-13.500).

436. Senate Hearing, supra note 434, at 12 (prepared statement of Robert S. Mueller, III).

437. Michael Abbell \& Bruno A. Ristau, 3 International Judicial AssistAncE: Criminal § 12-4-4(7), at 114 (1990); see Treaty on Mutual Assistance in Criminal Matters, June 12 - Aug. 18, 1987, U.S.-Bah., art. 1, para. 2(c), S. TrEATY Doc. No. 100-17, 100th Cong. 1 (1988) (requiring assistance in "executing request for searches and seizures"); id. art. 1, para. 4 (declaring that requests under treaty shall be executed in accordance with law of requested state). The scope of the treaty is determined by the definition of "offense," which includes conduct punishable as a crime under the laws of both jurisdictions, and under the laws only of the requesting state when they involve illegal narcotics or drug activity, theft, crime of 
that allegations of treaty violation be presented only to the executive authority of the requesting country and not to its courts, persons adversely affected by warrant equivalents or subpoenas do have recourse to the courts of the requested country to the extent that those courts are involved in obtaining the information. ${ }^{438}$ Because many other treaty partners lack a process equivalent to a subpoena duces tecum, the standards applicable to warrants are used for such countries. ${ }^{439}$

There are other extralegal ways to obtain evidence internationally. The Fourth Amendment to the United States Constitution

violence, fraud, or currency or financial transactions and are punishable by one year imprisonment or more. Id. art. 2, para. 1. A requested state may deny compliance if "the request has not established that there are reasonable grounds for believing: (i) that the criminal offense specified in the request has been committed; and (ii) that the information sought relates to the offense and is located in the territory of the requested state." Id. art. 3, para. 1(e). Further, a request for search, seizure and delivery of any article "shall be executed if it includes the information justifying such action under the laws of the requested state." Id. art. 15, para. 1; accord, Treaty on Mutual Legal Assistance in Criminal Matters, Jan. 28, 1988, U.S.-Belg., art. 7, S. TREATY Doc. No. 100-16, 100th Cong. 3 (1988) (executing request for search and seizure); Treaty on Mutual Legal Assistance in Criminal Matters, Mar. 18, 1985, U.S.-Can., art. XVI, para. 1, S. TREATY, Doc. No. 100-14, 100th Cong. 6 (1988) (requiring search and seizure request to be executed in accordance with requirements of law of requested state); Mutual Legal Assistance Treaty, Dec. 9, 1987, U.S.-Mex., art. 12, S. Treaty Doc. No. 100-13, 100th Cong., 6 (1988) (declaring that request for search, seizure and delivery of any object shall be executed if it includes information justifying such action under laws of requested party).

The treaty with the Netherlands is especially instructive. See Treaty on Mutual Assistance in Criminal Matters, June 12, 1981, U.S.-Neth., art. 6, T.I.A.S. No. 10,734 (agreeing that requested states shall execute request for search and seizure in accordance with its laws and practices if subject defense is punishable under laws of both parties by deprivation of liberty for period exceeding one year). If the law is specified in an annex,

[the] offense shall be deemed punishable under the laws of the requested state if the acts or omissions alleged, occurring in similar circumstances in the requested state, would constitute a criminal offense under the laws of that state. For purposes of this paragraph, purely jurisdictional elements of United States federal offenses, such as the use of the mails or interstate commerce, shall not be considered as essential elements of these offense.

Id. Further, the treaty provides:

A request to the United States for a search and seizure shall be accompanied by a statement made under oath before, or by a judge in the Kingdom of the Netherlands, which shall establish good cause to believe that an offense has taken place or is about to take place and that evidence of the offense is to be found on the persons or the premise to be searched, and shall provide a precise description of the person or premises to be searched. Such a statement shall be considered in the United States in Id. lieu of an affidavit sworn before a United States judicial officer.

438. AbBell \& Ristau, supra note 437, § 12-4-7(1), at 135.

439. Id. $\S 12-2-2(3)$, at 28 . 
has, at most, limited application to foreign searches conducted by either foreign or U.S. officials. ${ }^{440}$ It long has been recognized that the Fourth Amendment is a limitation only on official conduct by federal officers or, pursuant to its incorporation into the Fourteenth Amendment, state officers. It thus has no application to searches or seizures conducted by officers of foreign states. For Fourth Amendment purposes, they are like private citizens whose searches and seizures are not constrained by the Fourth Amendment (although they may be subject to common law damages actions). Until 1990, the major unresolved transnational Fourth Amendment question was whether the Amendment covered searches by U.S. officers outside the territorial limits of the United States.

In United States $v$. Verdugo-Urquidez, ${ }^{441}$ the United States Supreme Court decided that the Fourth Amendment does not apply to search and seizures by United States agents of property owned by a nonresident alien and located in a foreign country. ${ }^{442}$ It distinguished earlier cases involving the constitutional rights of American citizens subjected to adverse treatment abroad. ${ }^{443}$ The case arose after defendant Verdugo-Urquidez was apprehended by Mexican police in Mexico, transported to a United States Border Patrol station, and there arrested by United States marshals. ${ }^{444}$ After the arrest, agents of the American Drug Enforcement Agency (DEA) searched the defendant's Mexican residences for evidence of narcotics trafficking and involvement in the kidnapping and torture murder of a DEA special agent. ${ }^{445}$ The director general of the Mexican federal judicial police authorized the search, which then

440. Even though the assertion of official U.S. law enforcement power in a foreign country may offend the sovereignty of that foreign country, the foreign country may be unable to prevent an affront to its sovereignty, as a practical matter.

441. 494 U.S. 259 (1990).

442. Id. at 266 (stating that Framers "never suggested that the [Fourth Amendment] was intended to restrain the actions of the Federal Government against aliens outside of the United States territory"); (f. United States v. Barona, 56 F.3d 1087, 1095-96 (9th Cir. 1995) (holding Fourth Amendment inapplicable to wiretap of U.S. citizen obtained by cooperation between U.S. and foreign law enforcement officials, based on reasonableness of good faith belief of U.S. officers that tap complied with foreign law), cert. denied, $116 \mathrm{~S}$. Ct. 814 (1996).

443. Verdugo-Urquider, 494 U.S. at 270 (distinguishing Reid v. Covert, 345 U.S. 1 (1957)) (holding that wives of American servicemen could not be tried by court marshall because certain constitutional privileges apply outside territorial limits of United States). The Court found Reid distinguishable because Verdugo-Urquidez, unlike the wives in Reid, was not a United States citizen. Id.

444. Id. at 262.

445. Id. 
was carried out by DEA agents working together with Mexican federal judicial police officers. ${ }^{446}$

The Supreme Court majority reasoned that nonresident aliens are not within the class protected by the Fourth Amendment ${ }^{447}$ and that Fourth Amendment protections generally were not intended to apply beyond the borders of the United States. ${ }^{448}$ Justice Kennedy, writing separately, noted that it would be impracticable to apply the Fourth Amendment abroad because of "[t]he absence of local judges or magistrates available to issue warrants, the differing and perhaps unascertainable conceptions of reasonableness and privacy that prevail abroad, and the need to cooperate with foreign officials . . . "449 Justice Stevens thought the reasonableness clause of the Fourth Amendment applied, but not the Warrant clause. ${ }^{450}$ Justice Brennan, however, concluded that the Fourth Amendment protections should have as much reach as the authority of federal law enforcement officials. 451 Justice Blackmun, like Justice Brennan, argued that the Fourth Amendment applied, except that he felt that the Warrant clause was inapplicable because an American magistrate would lack the power to authorize a search abroad. ${ }^{452}$

Regardless of whether the Fourth Amendment applies at all to foreign searches, however, it remains true that a foreign search by U.S. officers potentially offends the sovereignty of the foreign state in which it occurred, thus potentially subjecting the United States and its citizens to retaliation, and the officials performing the search and seizure to punishment by the foreign country. Accordingly, the normal practice contemplates some formal legal channel for authorizing the foreign search.

When no MLAT is in effect, one might be tempted to suppose that the appropriate way to conduct a foreign search is simply for judicial process to authorize U.S. officers to conduct a search or to compel a third party to produce the desired evidence. There are two conceptual problems, however, with this approach: the affront

446. Id.

447. Id. at 265-66.

448. Id. at 266-68. Justice Brennan characterized the majority conclusion as turning only on the identity of the defendant and not on territoriality. Id. at 288 (Brennan, J., dissenting) (arguing that " $[\mathrm{t}]$ he focus of the Fourth Amendment is on what the Government can and cannot do ... not on against whom these actions may be taken").

449. Id. at 278 (Kennedy, J., concurring).

450. Id. at 279 (Stevens, J., concurring in the judgment).

451. Id. at 284-86 (Brennan, J., dissenting).

452. Id. at 297 (Blackmun, J., dissenting). 
to foreign sovereignty 453 and the likelihood that U.S. judicial power stops at the borders. Otherwise, the fact that criminal activity occurred within the district of the court issuing the process would support its issuance. There is a limited set of circumstances under which foreign subpoenas are authorized: when the person subject to the subpoena is a U.S. citizen or resident alien, and when there is some means of enforcing the subpoena within the United States. ${ }^{454}$

The foreign sovereignty problem is avoided when the local law of the foreign jurisdiction authorizes the search and seizure or otherwise compels the production of the desired evidence. In many cases, the standards for issuance of such foreign process are different from and lower than American standards for search warrants and subpoenas. ${ }^{455}$ Conversely, in the absence of a treaty commitment, foreign courts and agencies may be unwilling to authorize or to compel obtaining evidence to support a U.S. criminal investigation. Because no local crime can be established in the foreign country, foreign law may not authorize a search or compulsory process. This is the converse of the proposition in some American jurisdictions that local searches can occur only with respect to local crimes.

When local law of the foreign jurisdiction authorizes the search or seizure, there is little doubt that any Fourth Amendment reasonableness concerns are satisfied. ${ }^{456}$ Efforts in the United States to suppress evidence obtained in foreign countries uniformly

453. See Buenrostro v. Collazo, 973 F.2d 39, 43 (1st Cir. 1992) (concluding that warrantless home arrest and search in Virgin Islands could not be legitimated by New York law enforcement request, which was not equivalent to warrant); State v. Mathews, No. 20154, $1994 \mathrm{WL} 376131$, at *4 (Idaho, July 18, 1994) (réversing denial of suppression and concluding that state search warrant executed within Indian reservation was invalid because it invaded Indian national sovereignty).

454. 28 U.S.C. $\$ 1783$ (a) (1994) (authorizing subpoena of national or resident of United States who is in foreign country); see also id. § 1784(a), (b) (1994) (authorizing contempt proceeding to enforce subpoena served in foreign country and authorizing seizure of property within United States pursuant to such contempt finding).

455. Richard S. Frase, Comparative Criminal Justice as a Guide to American Law Reform: How Do the French Do It, How Can We Find Out, and Why Should We Care?, 78 CAL. L. REv. 539, 574-81 (1990) (stating that French law does not require warrants or probable cause, but does permit rogatory commissions to be executed only by federal police official or judge, and residential searches must be witnessed by resident or by two independent persons).

456. See United States v. Inigo, 925 F.2d 641, 656 (3d Cir. 1991) (citing United States v. Verdugo-Urquidez, 494 U.S. 259 (1990)) (rejecting argument that evidence seized by Swiss police incident to Swiss arrest should be suppressed in U.S. prosecution for extortion); United States v. Juda, 797 F. Supp. 774, 782-83 (N.D. Cal. 1992), aff'd, 46 F.3d 961 (9th Cir.), cert. denied, 115 S. Ct. 2632 (1995) (holding that Fourth Amendment applied to placement of beeper on sea-going vessel in Australia because American citizen was involved, but no Fourth Amend- 
have been unsuccessful on the rationale that the purpose of the exclusionary rule would not be served by excluding evidence based on the purported conduct of foreign law enforcement officers. ${ }^{457}$

Problems also arise with suspected criminal activity or with a potential criminal prosecution in a foreign country leading to a desire to search for and seize evidence in the United States. Except when treaty commitments, already reviewed in connection with foreign searches incident to U.S. crimes, obligate the United States to conduct searches on behalf of a foreign authority, the legal authority for such U.S. searches is uncertain. Explicit federal authority is not very helpful, because it is limited to depositions, ${ }^{458}$ is more or less based on the letters rogatory concept, and provides for appointment of commissioners to conduct examinations. 459

There is less certain authority for a state or federal magistrate to issue a search warrant based on a foreign request. If a U.S. warrant can be obtained based on a foreign request for evidence, however, the problem is solved from the perspective of foreign law enforcement authorities. Any sovereignty and power concerns are averted because state and federal magistrates uniformly have the power to authorize searches and seizures within their districts, as long as the criteria for warrants are satisfied. The problem is that the absence of a local crime may defeat probable cause.

There is general agreement for the proposition that probable cause for a search warrant necessitates the existence of two elements: the commission of a crime and property related to the crime being located in the district of the issuing magistrate. ${ }^{460}$ Assuming the property to be searched or seized is located within the district, the question is whether the crime, the commission of which must be established, must be local as well. There is some authority suggesting that a local crime must be established. ${ }^{461}$ On the other hand, informal conversations with state magistrates in Pennsylvania

ment violation because American authorities relied in good faith on advice from Australian officials that no warrant was required under Australian law).

457. United States v. Heller, 625 F.2d 594, 599-600 (5th Cir. 1980); ABbeLl \& RISTAU, supra note 437, § 12-2-1 (3), at 26-28 (citing Powell v. Zuckert, 366 F.2d 634 (D.C. Cir. 1966)).

458. U.S. ATtORNeys' MANUAL, supra note 433, § 9-13.540.

459. See 28 U.S.C. $\$ 1782$ (1994) (allowing district court to appoint person to take testimony or statement).

460. See, e.g., United States v. Rakowski, 714 F. Supp. 1324, 1330 (D. Vt. 1987) (citing United States v. Travisano, 724 F.2d 341, 345 (2d Cir. 1983)) (finding that probable cause for search warrant must be based on two propositions: (1) crime was committed; and (2) evidence of such crime is at location to be searched).

461. Commonwealth v. Nation, 598 A.2d 306, 310-11 (Pa. Super. 1991) (vacating conviction and concluding that being fugitive does not constitute crime in 
lead to the conclusion that search warrants regularly are issued based on affidavits by law enforcement officers from other states saying that the warrant is needed in connection with investigation of a crime committed in the other state. ${ }^{462}$

Unless the issuance of a search warrant based on a foreign crime is mandated by the Full Faith and Credit Clause of the United States Constitution, which ordinarily has only limited criminal law application and would have no application to a foreign request, this practice, if legal, suggests that evidence of a crime in a foreign country also would support the issuance of a search warrant by a federal or state magistrate. Alternatively, a foreign warrant or subpoena would have no effect in the United States for the same reasons discussed earlier that a U.S. warrant or subpoena would have no effect in a foreign country. ${ }^{463}$

\section{Excluding Wrongfully Obtained Evidence}

There are a number of possible consequences of a foreign search or seizure not being authorized by U.S. law, including situations in which the Fourth Amendment or other legal standards limiting searches and seizures apply, but have not been complied with, and circumstances in which raw power has been used. There are three pertinent consequences: (1) the exclusion, in any subsequent criminal prosecution under the "exclusionary rule," of the evidence illegally seized; (2) the criminal prosecution of, or a private damages action against, the searching and seizing officials; and (3) a simple refusal by the person holding custody of the desired property to allow the search and seizure.

Verdugo-Urquidez established the proposition that evidence seized in a foreign country is not subject to the Fourth Amendment exclusionary rule in a federal criminal prosecution. ${ }^{464}$ Whether evidence seized in the United States would be excluded in a foreign

Pennsylvania and therefore could not serve as basis for search warrant), appeal denied, 607 A.2d 252 (Pa. 1992).

462. See United States v. Paroutian, 299 F.2d 486, 488 (2d Cir. 1962) (reversing conviction on illegally obtained evidence and suggesting that letter from outof-state law enforcement authorities might have been sufficient basis to obtain search warrant).

463. The earlier discussion did explain that a foreign subpoena might be effective against a foreign citizen in the United States at least to the extent it could be enforced against property located in the issuing jurisdiction. Many foreign nations object to this practice, however.

464. United States v. Verdugo-Urquidez, 494 U.S. 259, 265-68 (1990). For further discussion of the Court's opinion in Verdugo-Urquidez, see supra notes 44152 and accompanying text. 
prosecution depends on whether the foreign country has an exclusionary rule. That leaves open the possibility that evidence seized in a foreign country might be excluded from a U.S. prosecution for some reason other than the Fourth Amendment warrant requirement, such as a synthesis of more general U.S., foreign and international legal concepts. 465 There is some authority in the VerdugoUrquidez opinion and in some state decisions making the exclusion of evidence turn on the reasonableness of a foreign search, measured by its compliance with the law of the location in which the search occurred. ${ }^{466}$ Gaps could be filled by the Human Rights Convention, even though the United States is not yet a party. ${ }^{467}$

On the other hand, the central purposes of the exclusionary rule may not be implicated by searches not conducted by U.S. offcials in their official capacities. The rationale articulated by the New Jersey Supreme Court in State v. Mollica ${ }^{468}$ is instructive. In Mollica, the New Jersey Supreme Court reasoned that constitutional limitations of one sovereign apply only to activities of that sovereign's officers. ${ }^{469}$ The court determined that its own constitutional search and seizure protections did not limit the activities of the federal agents who obtained telephone toll records in a manner complying with federal requirements but not complying with New Jersey requirements. ${ }^{470}$ It found the federal-state question analogous to the treatment accorded officers of a foreign country, "who, in the exercise of their own government's authority, are not subject to the federal constitution." 471 State constitutional limitations that are not applied to private citizens are not applied to officers of a foreign

465. Bentley, supra note 434, at 335-60, $387-97$ (1994) (evaluating competing approaches from opinions in Verdugo-Urquidez and suggesting new "international Fourth Amendment" based on combination of Fourth Amendment reasonableness standard and article 17 and 9(1) of International Covenant on Civil and Political Rights).

466. See Dillon v. State, 844 S.W.2d 139, 143-44 (Tenn. 1992) (holding that search and seizure conducted by federal agents in Florida was valid so long as agents conformed with federal law) (citing State v. Mollica, 554 A.2d 1315 (N.J. 1989)), cert. denied, Dillon v. Tennessee, 507 U.S. 988 (1995).

467. See Fernandez v. Wilkinson, 505 F. Supp. 787, 800 (D. Kan. 1980) (basing resolution of habeas corpus petition in part upon international norms of human rights, and, consequently, limiting arbitrary detention).

468. 554 A.2d 1315 (N.J. 1989).

469. Id. at 1324 .

470. Id. at 1328 .

471. Id. at 1325 (citing United States v. Calloway, 446 F.2d 753, 755 (3d Cir. 1971) (upholding admission of evidence obtained by Canadian police even though search inadequate by Fourth Amendment standards), cert. denied, 404 U.S. 1021 (1972)). 
jurisdiction. ${ }^{472}$ The "silver platter" doctrine, used to implicate American constitutional standards when foreign agents seize information abroad under the direction of American authorities, is based on the presence of agency between officers of the two sovereigns. ${ }^{473}$ The court stated:

In determining the validity of a search and seizure conducted by officers of another jurisdiction, the critical assumption that obviates the application of the state constitution is that the state's constitutional goals will not thereby be compromised ....

None of these constitutional values, however, is genuinely threatened by a search and seizure of evidence, conducted by the officers of another jurisdiction under the authority and in conformity with the law of their own jurisdiction, that is totally independent of our own government officers. Thus, in that context, no purpose of deterrence relating to the conduct of state officials is frustrated, because it is only the conduct of another jurisdiction's officials that is involved. Judicial integrity is not imperiled because there has been no misuse or perversion of judicial process. ${ }^{474}$ The New Jersey court did find some cases, however, suggesting the application of choice of law factors in deciding whether the forum state should apply the other state's search and seizure law. ${ }^{475}$

Regardless of whether evidence obtained from an unofficial search and seizure outside U.S. territory would be excluded in a U.S. criminal prosecution, a U.S. officer could be prosecuted by' a foreign country for conducting an unauthorized search and seizure there, based on the criminal law of that country. Whether a foreign private damages action could succeed against the U.S. officer depends on the civil or common law of that country. It also is conceivable that the foreign person harmed by such a search could

472. Id.

473. Id. at 1326 (citing People v. Touhy, 197 N.E. 849, 857 (Ill. 1935) (denying suppression of evidence seized by Wisconsin police)); see also Young v. Commonwealth, 313 S.W.2d 580, 581 (Ky. 1958) (citing Kaufman v. State, 225 S.W.2d 75 (Tenn. 1949) (admitting evidence in Kentucky seized by Missouri officers even though seizure contravened both Kentucky and Missouri constitutions)).

474. Mollica, $554 \mathrm{~A} .2 \mathrm{~d}$ at 1328 (citations omitted).

475. Id. at 1326 n.6 (citing People v. Orlosky, 115 Cal. Rptr. 598, 601 (Ct. App. 1974); People v. Saiken, 275 N.E.2d 381, 385 (Ill. 1971), cert. denied, 405 U.S. 1066 (1972); Burge v. State, 443 S.W.2d 720, 723 (Tex. Crim. App.), cert. denied, 396 U.S. 934 (1969)). 
successfully maintain an action against the U.S. officer brought in an American court. ${ }^{476}$ Whether such an action could succeed depends on whether a federal right can be shown to have been violated, and whether the foreign person would have standing in a section 1983 action. Both propositions are questionable under Verdugo-Urquidez, which undercuts the two elements of a section 1983 action by eliminating the Fourth Amendment protection in such a situation.

Whether an American common law action for damages-trespass or conversion, and possibly invasion of privacy-could be maintained depends on personal jurisdiction and choice of law, under the rules reviewed earlier. If the search were conducted in a foreign country by a U.S. officer, the person victimized by the search should have little difficulty filing suit in a U.S. court, and the U.S. court should have little difficulty obtaining personal jurisdiction over the U.S. officer conducting the search. On the other hand, it might be quite difficult for a U.S. citizen victimized by a foreign search to obtain personal jurisdiction in a U.S. court over the foreign officers conducting the search. Additionally, sovereign immunity should not be a problem because the assumption is that the search was unauthorized and thus outside the scope of any sovereign immunity. ${ }^{477}$

Assuming personal jurisdiction could be obtained, whether an American common law damages doctrine would apply depends on choice of law rules. All of the pertinent legal theories for damages here would be tort theories, and the traditional choice of law rule for torts is lex locus delicti. Application of this traditional rule would mean that the law of the place where the search occurred would be applied. That means U.S. law in the case of the U.S. search, but foreign law in the case of a foreign search. Modern choice of law rules, however, engage a more flexible interests analysis. Interest analysis is likely to focus on the law of the place where the search occurred, significantly mitigated by the interest of the other jurisdiction in successfully prosecuting crimes committed there.

\section{New Legal Institutions}

New public and private legal institutions are likely to be created, or at least considered, to respond to the jurisdictional challenges of the GII. Private institutional development, particularly

476. 42 U.S.C. $\$ 1983$ (1994).

477. Of course a good faith exception might extend the immunity beyond the scope of actual authority. 
arbitration, is probably the best response for civil disputes, but public institutional development may be necessary for criminal matters. These options are outlined below.

\section{A. Arbitration}

The best means for reducing uncertainty with respect to personal jurisdiction, choice of law and venue in civil cases is to use international arbitration. Arbitration is a dispute resolution process in which a binding decision is made by one or more private individuals under an agreement entered into by the disputants. The availability of arbitration thus depends upon the existence of an arbitration agreement, either entered into in advance for a class of disputes, or entered into after a particular dispute has arisen, limited to that dispute.

The legal position of arbitration depends on the willingness of regular courts to channel disputes to the arbitration forum when one of the parties tries to present them to another forum, and on the willingness of the regular courts to enforce an arbitration award. The first type of relationship between arbitration and the regular courts is frequently referred to as enforcement of the arbitration agreement or "compelling arbitration." 478 The criteria for compelling arbitration and for enforcing arbitration awards are similar, because award enforcement is a subset of arbitration agreement enforcement; when one enters into an arbitration agreement, one agrees either expressly or impliedly to comply with the award.

Because the power of an arbitrator is contractual, parties are obligated to arbitrate and to obey arbitration awards, but only when the dispute is within the scope of a valid agreement. ${ }^{479}$ Deciding whether a dispute is within a valid arbitration agreement presents the question of substantive arbitrability. ${ }^{480}$ Conceptually, there is no doubt that the question of substantive arbitrability is ultimately for a traditional court to decide, ${ }^{481}$ although courts must defer to

478. See generally Merrill Lynch, Pierce, Fenner \& Smith, Inc. v. Lauer, 49 F.3d 323, 327 (7th Cir. 1995) (holding that party cannot seek to narrow arbitration by suing in district other than district where arbitration is occurring and applying $\S 4$ of Federal Arbitration Act and generally reviewing law under which one sues to compel arbitration).

479. See generally Henry H. Perritt, Jr., Dispute Resolution in Electronic Network Communities, 38 VILL. L. REv. 349 (1993) (exploring difficulty of designing private governance mechanisms that encompass disputes involving third parties, not signatory to contracts defining mechanism).

480. Alternatively, procedural arbitrability is the question whether appropriate procedures have been followed in presenting the dispute to the arbitrator.

481. AT\&T Technologies, Inc. v. Communications Workers, 475 U.S. 643, 649 
arbitral decisions on questions of substantive arbitrability when the agreement contemplates arbitrator decisions on those questions. ${ }^{482}$

If a dispute is substantively arbitrable, the parties to the arbitration agreement are obligated to use the arbitration process and through that agreement are considered to have waived any legal power to present the dispute to a regular court instead of arbitration. ${ }^{483}$ Once disputes have been arbitrated and the arbitrator has issued an award, that award is enforceable, either in a breach of contract action seeking specific performance of the arbitration agreement or in a summary proceeding under an arbitration award enforcement statute. ${ }^{484}$ The basic legal framework for arbitration is the same regardless of whether the arbitration is purely domestic or whether it is international. 485 Until recently, certain statutory

(1986) (stating that courts have ultimate say on whether dispute is substantively arbitrable).

482. See First Options of Chicago, Inc. v. Kaplan, 115 S. Ct. 1920, 1923 (1995) (holding that court "should give considerable leeway to the arbitrator" when parties agreed "to submit the arbitratibility question itself to arbitration").

483. See 9 U.S.C. $\S 4$ (1994) (stating when federal court has power to compel arbitration); UNIFORM ARBITRATION ACT (UAA) \$ 2, 7 U.L.A. 68 (1985) (granting same power to state courts to order parties to continue arbitration); Convention on the Recognition and Enforcement of Foreign Arbitral Awards, Jun. 10, 1958, art. II, para. 3, 21 U.S.T. 2517, 330 U.N.T.S. 3 (1958) [hereinafter New York Arbitration Convention] (requiring courts of contracting states to refer arbitrable agreement to arbitration as long as they find arbitration agreements to be valid); see also Howard Fields \& Assocs. v. Grand Wailea Co., 848 F. Supp. 890, 892-95, 899 (D. Haw. 1993) (citing Volt Info. Sciences, Inc. v. Board of Trustees, 489 U.S. 468 (1989)) (staying federal court litigation pending arbitration; explaining relationship between Federal Arbitration Act and state arbitration law, acknowledging that Volt allows choice of law provision in arbitration agreement to apply state arbitration law rather than federal arbitration agreement law).

484. See 9 U.S.C. $\S \S 9,10$ (1994) (authorizing federal court enforcement of award if parties have so provided in their agreement and requiring enforcement unless it can be shown that: (1) award was procured by corruption, fraud or undue means; (2) where there was evident partiality or corruption in arbitrators; (3) where arbitrators were guilty of misconduct in refusing to postpone hearing or in refusing to hear pertinent evidence; or (4) where arbitrators exceeded their power); UAA, supra note $483, \S \S 8,12$ (similar power and criteria for state courts); New York Arbitration Convention, supra note 483, art. III (providing for enforcement of arbitration awards); id. art. V, para. 1 (allowing for refusal of enforcement of arbitration award only if: (1) agreement was invalid; (2) party seeking to avoid enforcement was not given appropriate notice; (3) award is outside scope of arbitration agreement; (4) composition of arbitral body was in violation of agreement or law of country where arbitration took place; or (5) award has not yet become binding or has been set aside by competent authority where award was made); id. art. V, para. 2 (allowing for refusal of enforcement if law of country where enforcement is sought does not allow that type of dispute to be arbitrated because enforcement would be contrary to public policy of that country).

485. See 9 U.S.C. $\S \S 201-08$ (1994) (providing for enforcement of arbitration agreements and awards under New York Convention in accordance with criteria and procedures generally applicable to domestic arbitration); accord, Jain v. de Mérê, 51 F.3d 686, 688 (7th Cir.) (ordering arbitration between non-citizens 
claims were not arbitrable as a matter of public policy in the United States, but the Supreme Court has significantly relaxed this doctrine. Now, it is reasonable to presume that almost any subject matter can be arbitrable, at least if the arbitration agreement clearly manifests an intent to make it arbitrable. ${ }^{486}$

Assuming that there are no artificial limitations on the types of claims that may be arbitrated, arbitration offers important advantages in the GII context. One advantage is that arbitrators can be selected, ${ }^{487}$ and arbitration procedures and choice of law can be specified in the arbitration agreement to suit the nature of claims arising in the GII better than regular judicial procedure and generalist judges. A second advantage, given the transnational character of many GII transactions, is that the New York Arbitration Convention provides greater certainty as to the enforceability of international arbitration awards than is available with respect to the enforceability of the judgments of regular courts under an MLAT. Arbitration facially implicates decisionmaker expertise, choice of law and decision enforcement advantages. Additionally, signing a forum-selection clause leading to arbitration waives objections both to personal jurisdiction and to venue. ${ }^{488}$ Finally, arbitrators usually can be given authority to award a variety of remedies, including punitive damages. ${ }^{489}$

under agreement providing for application of French law), cert. denied, $116 \mathrm{~S}$. C.t. 300 (1995).

486. See Gilmer v. Interstate/Johnson Lane Corp., 500 U.S. 20, $26-27$ (1991) (allowing arbitration of age discrimination claims under individual employment agreement); Mitsubishi Motors Corp. v. Soler Chrysler-Plymouth, Inc., 473 U.S. 614,625 (1985) (rejecting presumption against arbitration of statutory claims and finding antitrust disputes to be arbitrable); Scherk v. Alberto-Culver Co., 417 U.S. 506 (1974) (concluding that international arbitration agreement may provide for binding arbitration of statutory securities law claim). But see Wolf v. Gruntal \& Co., 45 F.3d 524, 529 (1st Cir. 1995) (finding that arbitrator lacked jurisdiction over federal securities law claim because not explicitly submitted in writing and therefore award had no res judicata effect in subsequent court litigation).

487. One distinguished commentator, recognizing the advantages of institutional arbitration, as under the Court of Arbitration of the International Chamber of Commerce in Paris, suggests the establishment of a single world-wide institution, privately created and administered that would improve institutional international arbitration. Smit, supra note 357 , at 9.

488. See The Bremen v. Zapata Off-Shore Co., 407 U.S. 1, 12-14 (1972) (stating that freely negotiated forum-selection clauses should be given full effect, regardless of jurisdictional or venue objections, because such clauses are "indispensible" to international contracting and represent manifestation of parties' intent).

489. See Mastrobuono v. Shearson Lehman Hutton, Inc., 115 S. Ct. 1212, 1217-19 (1995) (determining that contract allowed arbitrator of dispute between securities brokerage and customers to award punitive damages). According to the Court, the choice of law provision pointing to New York law did not require appli- 
Realizing the advantages of arbitration requires the parties to understand and to specify, where appropriate, the choice of procedure and choice of substantive law for their arbitrations. In general, arbitration procedure is entirely a creature of the arbitration agreement. Thus, whether discovery is permitted, or whether fact or notice pleading is to be utilized, and the applicability of different rules of evidence, all are matters to be defined by the parties in their arbitration agreement. They may incorporate by reference rules of procedure issued by various bodies sponsoring arbitration such as the American Arbitration Association, the International Chamber of Commerce or the UN Commission on International Trade Law (UNCITRAL). 490

Choice of substantive law historically has been a bit trickier, although there is early authority for party autonomy, meaning the notion that the party should be entirely free to choose the substantive law to be applied.491 Indeed, there is a growing trend to allow arbitrators to refer to general commercial law without the necessity of finding any roots in the issuances of national legal institutions. This amounts to an endorsement of lex mercatoria in the arbitration context. 492 The only reason that an express reference to lex mercatoria or any other source of private law should not be permissible is a positivist theory of law, which denies the efficacy of any source of law other than a conventional legislature or court.

Private dispute resolution offers significant advantages for dealing with disputes that arise in cyberspace. Through private dispute resolution arrangements such as contractual arbitration, disputants

cation of the New York doctrine against punitive damages by arbitrator because that was procedural and conflicted with the Federal Arbitration Act. Id. For an indepth analysis of punitive damages in arbitration cases, see John Y. Gotanda, Awarding Punitive Damages in International Commercial Arbitrations in Wake of Mastrobuono v. Shearson Lehman Hutton, Inc., 38 HARV. INT'L L.J. (forthcoming 1996).

490. See American Arbitration Association Commercial Arbitration Rules, art. 20 (1995) (evidence); id. art. 24 (1995) (default provision); UNCITRAL Arbitration Rules, art. 24-25 (1976) (evidence and hearings); id. art. 28 (1976) (default); International Chamber of Commerce, art. 24 (1975) (finality and enforceability of award).

491. See generally Okezie Chukwumerije, Choice of Law in International Commerclal Arbitration 107-08 (1994). But see Vita Food Prods., Inc. v. Unus Shipping Co., [1939] App. Cas. 277, 290 (holding that choice of law may be disregarded if choice is not bona fide where there is public policy ground for avoiding it).

492. See Hutton v. Warren 150 Eng. Rep. 517 (M \&\&W 1838) (endorsing use of extrinsic evidence of custom and usage in disputes over commercial transactions); CHuKwumerIJE, supra note 491, at 110-17 (discussing sources of law within lex mercatoria, including those of UNCITRAL and International Institute for the Unification of International Private Law (UNIDROIT)). 
can provide in advance a channel for submission and resolution of a defined class of disputes. They can agree on specialized decisionmakers, as in labor, complex commercial, construction and international arbitration, selected from panels of pre-screened individuals. They can specify the procedure to be used, including the details of pleading; the possibility of summary resolution on the pleadings or before a hearing; how discovery, if any, will work; how cases are to be presented to the decisionmaker; what the decisionmaker may consider; limitations on how long the process can take; the form of the decision; and remedies. Additionally, they can allocate costs, providing for prepayment of all or some of the cost by one or both parties. They can, to some degree, also allocate decisionmaking responsibility between the private decisionmaker and an enforcing or reviewing court as to the scope (subject matter jurisdiction) of the private forum.

Private dispute resolution such as arbitration offers advantages over traditional government-sponsored dispute resolution because private institutional arrangement can employ whatever modes of communication and recordkeeping the parties wish. For example, there is no legal impediment to writing an arbitration agreement providing that everything, including the hearing itself, be conducted remotely through computer networks. Domestically, under the Federal Arbitration Act, ${ }^{493}$ and under the Uniform Arbitration Act, federal and state courts are obligated to enforce arbitration decisions reached without corruption and within the scope of the arbitration agreement without inquiry into the merits of the underlying dispute. ${ }^{494}$

Arbitration also offers significant advantages in the international context. The United States is not a signatory to any treaty that provides for enforcement of civil money judgments across international boundaries. While the common law doctrine of comity and the enactment of the Uniform Recognition Act ${ }^{495}$ by about half the states, provide a vehicle for enforcing foreign judgments in some circumstances, the prospect of obtaining practical relief through a civil judgment in an international dispute is uncertain. On the other hand, the United States and most other developed

493. 9 U.S.C. $\$ \S 1-16$ (1994).

494. The Uniform Arbitration Act allows a court to vacate an arbitration decision only in rare circumstances. Id. $\S 10$ (listing grounds for order vacating decision: fraud, corruption, arbitrator misconduct and instances where arbitrator exceeded his or her power).

495. See Uniform Recognition Act, supra note 275, at 263. 
countries are parties to the New York Convention. ${ }^{496}$ Under this convention, the courts of the signatories are obligated to enforce international arbitration awards with only the most limited grounds for declining enforcement. Thus, parties to international cyberspace transactions can greatly increase the certainty of dispute resolution by entering into an international arbitration agreement.

Of course, private dispute resolution, as described in this paper, is a contractual matter. A third party, for instance in a tort context, cannot be obligated to arbitrate under an agreement between two others. Nevertheless, this limitation may be more apparent than real in cyberspace. For one thing, the purported third party actually may be a party to contract terms specified in advance by service providers, much as the America Online terms of service constitute the contents of the contract between America Online and a subscriber. There is no reason that the same idea cannot work in a less commercial context, as when a World Wide Web server specifies "terms of service" on a Web page and makes it clear that a user of that page agrees to be bound by those terms of service. Such terms of service can provide for arbitration. While a consumer might seek to avoid the conclusion that she is a party to the contract on the grounds that she had no bargaining power or did not have actual knowledge of the announced terms, existing case law-both substantive contract and forum selection law-disfavors such arguments. Moreover, even if a third party were not bound to submit a dispute to arbitration, the arbitration arrangement could include a mechanism for making the arbitration forum available on a voluntary basis to the third party. If the arbitration alternative were perceived as fair, cheap and quick, many third parties would resort to it instead of going to court.

It is appropriate for those interested in the healthy development of cyberspace to begin putting some of these ideas into practice. In particular, it is practical to define a class of intellectual property, personal privacy and consumer protection (and possibly defamation, intentional infliction of emotional distress or intentional interference with contract) disputes that would be within the scope of a particular arbitration mechanism. Also, interested persons can begin drafting a master or model arbitration agreement, defining how the procedure would work, including all of those procedural elements identified above. In particular, the drafters can

496. M.J. Bowman \& D.J. Harris, Multilateral Treaties: Index and CurRENT STATUS 230-31 (1984 \& Supp. 1995) (indicating 95 parties to New York Convention, including U.S., France, Japan, United Kingdom, Germany and Canada). 
explain in some detail how these procedural elements would be accommodated through electronic networking.

A comprehensive arbitration agreement for cyberspace disputes should include prominent notice to third parties with clear procedures for allowing them to opt into the arbitration mechanism. In so doing, the best features of Magnuson-Moss ${ }^{497}$ consumer arbitration could be used, and the worst features avoided. ${ }^{498}$

\section{B. United States Court for Cyberspace}

To solve the third party problem inherent in arbitration, most mechanisms rely on finding some kind of contractual obligation to participate in arbitration. Of course, this can arise after the third party is involved in a dispute under the incentives discussed above. Alternatively, a person appearing to be a third party actually may be a second party in the sense that he or she may have consented to arbitrate by the mere act of entering cyberspace. Both of these theories for dealing with tort claims, however, are limited. The former is limited by the willingness of the disputant to submit to arbitration. The second is limited by the persuasiveness of the implied contract formation against a reluctant disputant, and by the existance of a "notice of consent to arbritrate" on the Internet.

Another, admittedly more speculative, possibility is for the U.S. Congress to reinvigorate the idea of extraterritorial domicile, used most notably in the operation of the United States Court for China. ${ }^{499}$ The Congress could enact legislation setting up a "United States District Court for the District of Cyberspace," which would have jurisdiction for all claims arising in cyberspace over anyone entering cyberspace. There are at least three problems with this approach, however. First, the jurisdiction of the United States Court for China was based on U.S. citizenship rather than on mere physical presence in China. ${ }^{500}$ Second, to the extent that cyber-

497. See 15 U.S.C. $\S \S 2301-12$ (1994) (providing consumers with option to resort to informal dispute settlement procedures for consumer complaints).

498. Craig v. Hyundai Motor Am., Inc., No. 94-5372, 1995 WL 380072, at *3 (E.D. Pa. June 26, 1995) (awarding attorney's fees for successful arbitration under Magnuson-Moss Act); Lipham v. General Motors Corp., 665 So.2d 190, 192 (Ala. 1995) (filing lawsuit after nonbinding Magnuson-Moss arbitration failed).

499. See David J. Bederman, Extraterritorial Domicile and the Constitution, 28 VA. J. INT'L L. 451, 460-70 (1988) (discussing United States Court for China). The author appreciates the suggestion from David Straite, Villanova Law School Class of 1996, which led to this analysis.

500. Act of June 30,1906 , ch. 3934, $\S \S 2,4,34$ Stat. 814; see also Bederman, supra note 499 , at $462 \& \mathrm{n} .50$ (noting that "the Court for China operated like any other federal district court in the United States," except that its jurisdiction was 
space extends far beyond U.S. borders, the U.S. Congress lacks jurisdiction to prescribe under international law. ${ }^{501}$ Third, entry into cyberspace is an amorphous concept, and no doubt would engender innumerable disputes as to whether venue is appropriate in the new cyberspace court or in a regular district or state court.

Implementation of a United States Court for Cyberspace would differ somewhat depending on whether its jurisdiction was strictly national. If the court had only national jurisdiction, it would be available for claims, for example, by citizens of Vermont against citizens of Florida involving Internet communication moving through servers in Virginia, Missouri and Oregon. Absent some new forum, priviate or statutory, such a dispute might be litigated in state or federal court in Vermont, Florida or any of the states involved, with the attendant uncertainty and inconvenience. To reduce such problems, the Congress could establish a new Article III court ${ }^{502}$ with removal jurisdiction over any claims arising in cyberspace.

The Seventh Amendment entitlement to jury trial in civil cases $^{503}$ is a potentially serious problem, but at least for initial consideration, juries should be allowed and they could be "cyber-juries." 504 The new court would have its own procedure that would be entirely electronic. Obviously, this would necessitate development of an entirely new set of procedural rules, although the basic attributes of procedure familiar under the Federal Rules of Civil Procedure could be adapted reasonably easily to the electronic context, including electronic filing, electronic service, with an e-mail return receipt used for proof of service, electronic interrogatories, production of documents, and requests for admission, electronic pre-trial orders, electronic hearings and electronic judgments. The only procedural features not easily accommodated by current modes of Internet communication are oral depositions and live

limited to "civil cases against American citizens residing in China . . . and . . . crimes committed by its citizens residing there").

501. But of. Dainese v. Hale, 91 U.S. 13, 15 (1875) (holding consular jurisdiction constitutional in "Pagan and Mahometan countries" provided that such jurisdiction is created pursuant to treaty and U.S. law); see also Bederman, supra note 499 , at 461 (noting that extraterritorial judicial authority was found constitutional).

502. An Article I court also could be established, but would be less useful because it could not be given jurisdiction over private disputes such as defamation and invasion of privacy likely to arise in cyberspace. See Northern Pipeline Constr. Co. v. Marathon Pipe Line Co., 458 U.S. 50 (1982).

503. U.S. ConST. amend. VII ("In Suits at common law, ... the right of trial by jury shall be preserved ....").

504. A "cyber-jury" could be impaneled through the Internet and would participate electronically. 
presentations of witnesses. While these could be done by video conferencing, a procedure limited to currently available applications on the Internet simply could dispense with them..$^{505}$

In effect, then, the United States Court for Cyberspace would be a new alternative forum that could be elected by either party to a cyberspace dispute and would substitute electronic procedure for a conventional procedure. No doubt, privately developed processes are superior, and a statute establishing the new court could contain placatory language encouraging parties to submit to privately developed arbitration following the Virtual Magistrate model. Indeed, a new version of Rule 12 could emphasize party consideration of such alternatives.

In the international context, the notion of a congressionally established cyber-court becomes more difficult and much more controversial. These paragraphs sketch the most ambitious possibility as a starting point for further analysis and discussion. The Congress would enact a statute establishing a United States Court for Cyberspace having jurisdiction over all disputes arising in cyberspace in which one of the parties is a U.S. citizen or in which either party elects to litigate in the new court. Of course, merely because Congress gives a new tribunal jurisdiction does not necessarily oust foreign courts of jurisdiction, and one could expect continuing controversy over whether judgments of the cyber-court would be recognized by foreign courts.

The international acceptability of the new court could be increased by appointing foreign judges to it, rather like the constitutional court of Bosnia. If the new court is to have Article III powers as a matter of American constitutional law, all of its judges must have life tenure and be subject to Senate confirmation. ${ }^{506}$ On the other hand, there is nothing on the face of Article III that forecloses appointment of foreign citizens to judicial positions. ${ }^{507}$

What superficially appears to be an extraordinary extraterritorial assertion of U.S. power could be made more acceptable by emphasizing that the new court is meant simply to fill the gap left by the inability of international arbitration to bind third parties, and

505. Whether there would be procedural due process or Seventh Amendment problems presents interesting questions for further analysis.

506. See U.S. CoNST. art. III, $\$ 1$ ("The Judges, both of the supreme and inferior Courts, shall hold their Offices during good Behaviour .... Courts considered to be territorial courts (or "legislative courts"), however, have as their source of authority Article IV, $\S 3$, not Article III, and the judges would not have life tenure. United States v. Starling, 171 F. Supp. 47, 49, 54 (D. Alaska 1959).

507. Obviously, this matter deserves further analysis and consideration. 
the absence of other international mechanisms. The Congress could commit itself to abolish the new court at such time as international machinery is established under U.N. auspices or otherwise. Of course, if the court were to be abolished, the foreign judges still would enjoy the right to receive their salaries, assuming the court is an Article III court. While the questions of judicial tenure, international acceptability and jury accommodation are certainly serious, ${ }^{508}$ a U.S. Court for Cyberspace, tailored to the realities of the GII, almost completely vitiates the personal jurisdiction problems discussed above. This advantage, combined with the benefit of having at least some judges who would acquire a sophisticated understanding of the nature of cyberspace disputes, makes a cyber-court, especially domestically, an interesting possibility worth pursuing further.

\section{Development and Application of Private Rules for the GII}

Choice of law includes more possibilities than just the law of different states or nations; increasingly, contracting parties, litigants and courts recognize that private bodies of law are worthy of consideration in choice of law analysis. This is particularly true in international arbitration. Legal disputes arising in the GII almost certainly will involve specialized substantive legal principles. There are a variety of ways in which these principles can be brought to bear in cases decided by arbitrators and judges, but perhaps the most general way is through lex mercatoria. ${ }^{509}$ The principle of lex mercatoria has its roots in the fourteenth and fifteenth centuries in Europe, and represents the customary law of the trade fair. In recent years, after a period of diminished legitimacy, ${ }^{510}$ lex mercatoria has again become attractive as a body of general commercial law to be applied to international disputes, especially in disputes heard by

508. Additionally, choice of law becomes increasingly difficult under the rubric of Erie because cyberspace does not lie in any particular state from which substantive law can be drawn.

509. See ChukwumerJje, supra note 491, at 110-14 (discussing evolution of lex mercatoria from Middle Ages to present).

510. There are both English and American cases which limit lex mercatoria. See National Metro. Bank v. United States, 323 U.S. 454, 456 (1945) (holding that federal statutes supersede law of merchant); President \& Directors of Manhattan Co. v. Morgan, 150 N.E. 594, 598 (N.Y. 1926) (holding that applicable statutes for negotiable instruments override law of merchants); Pan Atl. Ins. Co. v. Pine Top Ins. Co., 3 All E.R. 581, 582-83 (1994) (stating that 1906 statute supplants law of merchants); Container Transp. Int'l Inc. v. Oceanus Mut. Underwriting Ass'n, [1984] Lloyd's Rep. 476, 476 (concluding that statutes may supersede law of merchants). 
arbitrators. ${ }^{511}$

Despite the lower probability that lex mercatoria explicitly would be applied by an American court hearing a purely domestic dispute or by an arbitrator hearing a purely domestic dispute, the doctrine illustrates generally the variety of sources of customary law that are available. Other concrete possibilities include treaties, at least when they have been ratified by most nations; model statutes, at least when they have been widely adopted by legislatures; and standards of good practice adopted by trade bodies. ${ }^{512}$ Beyond that, expert testimony can flesh out generally accepted custom. Thus, lex mercatoria is not conceptually all that different from the use of trade custom to interpret contract provisions. Indeed, the Uniform Commercial Code specifically allows the use of trade custom and the law merchant to interpret commercial contracts. ${ }^{513}$ Lex mercatoria also is recognized as a source of commercial law transcending narrower national concepts. ${ }^{514}$ It is well recognized that almost any legal text requires some interpretation when it is being applied, and that extrinsic evidence is useful in the interpretation process.

Cyberspace needs an appropriate set of substantive doctrines to be applied by arbitrators or others under the lex mercatoria umbrella. For those interested in developing specialized rules for the GII, much can be done by getting interested persons together and writing model statutes and codes of good practice. Existing mechanisms like the Commissioners on Uniform State Laws can be used, or ad hoc forums can be assembled. Such efforts, however, must manage a variety of tensions successfully if they are to influence dispute resolution. First, the broader the scope of the group that agrees to a set of rules or principles, the more influential the rules

511. Chukwumerje, supra note 491 , at 114-15.

512. Id. at 112-13 (explaining sources of customs, usages and uniform law of international trade).

513. U.C.C. § 1-103 (1995) (indicating that law merchant will be used to supplement U.C.C. provisions unless specific U.C.C. provision controls).

514. One of the best examples is Alaska Textile Co. $v$. Chase Manhattan Bank, N.A., 982 F.2d 813 (2d Cir. 1992), in which the court of appeals explained the concept of a letter of credit and its origins in the lex mercatoria as internalized into English common law by Lord Mansfield. Id. at 816. The relations between the beneficiary and issuer of letters of credit are to be determined largely by lex mercatoria as expressed in the uniform customs and practices for documentary credits (UCP) even though it is not "law." Id.; see also Pribus v. Bush, 173 Cal. Rptr. 747, 749 \& n.5 (Cal. Ct. App. 1981) (relying on lex mercatoria to fill in gaps in U.C.C. as to whether endorsement of promissory note effectuated on separate piece of paper was effective to negotiate note and reviewing history of lex mercatoria, or common law of merchants); Mirabile v. Udoh, 399 N.Y.S.2d 869, 870-71 (Civ. Ct. 1977) (relying on lex mercatoria to enforce payment of money order by issuing bank even though payment had been stopped and maker's money refunded). 
or principles are likely to be. But the broader the group, the more difficult forming consensus will be. Second, the more specific the rules or policies, the more likely they will be outcome determinative. Yet increased specificity creates the likelihood that a particular dispute will be outside the scope of the rules, and forming a consensus will be more difficult. Nevertheless, struggling with these tensions is something that legislators and mediators do all the time, and thus the effort may be worthwhile if there is widespread concern about the inappropriateness of existing legal doctrine or about uncertainty because existing legal doctrines are very general.

The same initial drafting efforts can serve a number of different purposes. They can conclude with a private code of good practice to be applied by arbitrators. As another possibility, they may serve as the initial stages of an effort to write an international code of computer crimes. Or, they can provide the initial stages of an effort to write a model statute covering civil and criminal wrongs, to be adopted by national jurisdictions. Such a preliminary private drafting effort need not distinguish at the outset between civil and criminal liability. Instead, the drafters should concentrate on identifying subject matter within the scope of the code, identifying specific rights, duties and privileges, and deciding only at the end of the process where criminal, as opposed to civil, liability is appropriate.

Harmonization in some substantive areas will be easier than in others. There should be little difficulty in agreeing to define as wrongful ${ }^{515}$ conduct covered in the Federal Computer Fraud and Abuse Act ${ }^{516}$ because few legitimate interests are adversely affected by civil actions or criminal prosecutions for such conduct. Computer terrorism ${ }^{517}$ and large-scale international computer financial fraud would fall within the subjects defined by this Act. The area that would probably be next in order of difficulty is intellectual property infringement, not because the controversies over intermediary liability are insubstantial, but because substantial harmonization has already occurred through the GATT Uruguay Round negotiations. Next may be access and disclosure violative of the Electronic Communications Privacy Act (ECPA) ${ }^{518}$.Here, the difficulty will be not with unauthorized access, which significantly over-

515. "Wrongful" in the sense used in the text includes both crimes and civil wrongs such as torts and breaches of contract.

516. 18 U.S.C. \& 1030 (1994).

517. For a further discussion of international computer terrorism, see appendix, infra notes 536-82 and accompanying text.

518. 18 U.S.C. $\S \S 2510-22,2701-11$ (1994). 
laps the Computer Fraud and Abuse Act, but with disclosure by service providers. Nevertheless, because ECPA allows substantial room for a private contract, it may be feasible to agree on a framework like ECPA. Defamation, on the other hand, may not be a source of difficultly because the basic principles for defamation are widely accepted. The standards for intermediary liability, of course, will be much more difficult, as they are even within the United States. Finally, database privacy will be complicated, because of the significant differences between the European Union Directive and U.S. law. ${ }^{519}$ Nevertheless, the need for some degree of harmonization to facilitate trade between the European Union and other countries may make this not entirely beyond reach.

\section{International Courts}

The International Court of Justice (ICJ) is actually an arbitration body, whose jurisdiction is limited to disputes between nationals. Some scholars have suggested initiatives to improve its institutional framework for dealing with a broader range of international legal disputes. ${ }^{520}$ Moreover, at least one commentator has suggested giving the ICJ jurisdiction over international crimes and over state crimes where fugitives have crossed state borders. 521

Currently, an International Criminal Court is being discussed under U.N. auspices. ${ }^{222}$ The world could deal with criminal con-

519. For a discussion of the European Union Directive, see Rosario Imperiali d'Afflitto, European Union Directive on Personal Privacy Rights and Computerized Information, 41 VILL. L. REV. 305 (1996); Robert M. Gellman, Can Privacy Be Regulated Effectively on a National Level? Thoughts on the Possible Need for Intermational Privacy Rules, 41 VILL. L. REv. 129 (1996); Charles R. McManis, Taking TRIPS on the Information Superhighway: International Intellectual Property Protection for Emerging Computer Technology, 41 VILL. L. REv. 207 (1996). Additionally, I foresee harmonization of obscenity law being just as difficult, if not more so.

520. See John H. Barton \& Barry E. Carter, International Law and Institutions for a New Age, 81 GEo. L.J. 535, 547, 560 (1993). Barton and Carter suggest the following: the consideration of a GATT Antitrust Code; binding arbitration in NAFTA; making the judgments of the International Court of Justice (ICJ) enforceable in domestic courts as are arbitration awards under the New York Convention; more flexible procedures for the ICJ; further elaboration of an international common law; acceptance by the United States that rights recognized by the U.S. Constitution or International Human Rights Convention govern the U.S. government when it acts abroad; and the acceptance by the United States that international treaties and executive agreements can be enforced by U.S. domestic courts. Id. at $550,560-61$.

521. See Barbara M. Yarnold, International Fugrtives: a New Role for THE INTERNATIONAL COURT OF JUSTICE 105 (1991).

522. See Madeleine $\mathrm{K}$ Albright, International Law Approaches the Twenty-First Century: A U.S. Perspective on Enforcement, 18 FordHAM INT'L L.J. 1595, 1605 (1995) (reporting Clinton administration interest in International Criminal Court proposal); American Bar Association, American Bar Association Task Force on an Interma- 
duct in the GII by bringing certain types of electronic piracy and computer crimes within the jurisdiction of the court. In addition, problems of international search and seizure, as when the evidence pertinent to a crime in one country is contained on a network server located in another country, can be addressed by broader adoption of legal assistance treaties on the model suggested by the U.N. draft treaty. Extradition treaties need to be modernized as well to include computer crimes within enumerated extraditable offenses. ${ }^{523}$

For this to be a practicable solution, however, computer crimes must be perceived as sufficiently serious to warrant their inclusion in international documents and institutional jurisdictions which heretofore focused primarily on war crimes and terrorism. Certain computer crimes, such as terrorism by means of computer, ${ }^{524}$ or crimes involving computerized financial transactions, might be an appropriate starting point. Moreover, there is a need for further harmonization of substantive criminal law concepts pertaining to computer crimes, both to make transnational jurisdiction over computer crimes acceptable for new international bodies, and to satisfy the dual criminality requirements of both extradition and legal assistance treaties.

Politics is important in determining which alternative will be selected. It is, therefore, useful to assess the likely positions of different groups interested in the development of the GII. In-

tional Criminal Court Final Report, 28 INT'L LAW. 475 (1994) (reporting on annual meeting of ABA which adopted recommendation on International Criminal Court); James Crawford, The ILC Adopts a Statute for an International Criminal Court, 89 AM. J. INT'L L. 404 (1995) (reporting on basic parameters for draft statute developed by International Law Commission); Paul D. Marquardt, Law Without Borders: The Constitutionality of an International Criminal Court, 33 Colum. J. Transnat'l L. 73 (1995) (criticizing analyses of objections to recommendation of permanent international criminal court); Virginia Morris \& M.-Christiane Bourloyannis-Vrailas, The Work of the Sixth Committee at the Forty-Ninth Session of the UN General Assembly, 89 AM. J. INT'L L. 607, 613-14 (1995) (reporting on discussions of recommendation for international criminal court and suggesting that concept might be ripe now for negotiation of treaty establishing such court); Jelena Pejic, The International Criminal Court: Issues of Law and Political Will, 18 Fordham INT'L L.J. 1762, 1762 (1995) (suggesting that international conference of plenipotentiaries may be convened to draft convention on establishing international criminal court in late 1995).

523. But see Senate Hearings, supra note 434, at 4 (prepared statement of Allen J. Kreczko) (noting advantages of dual criminality instead of enumerated-crimes approach and specifically mentioning that dual criminality approach obviates need to renegotiate treaties to include new offenses such as computer-related crimes).

524. Information technology might be the instrument of a terrorist threat aimed at conventional property or person, or a computer system might be the target, for example, if a terrorist threatened to disable or corrupt a system for managing financial transactions. For a further discussion of the criminal arena, see appendix, infra notes 536-82 and accompanying text. 
termediaries, frequently known as "system operators" or "sysops," in the United States, almost always prefer to minimize the legal control of their activities. It is likely that they would oppose any new initiative to develop new international or other machinery to enforce legal obligations against participants in cyberspace. While their real interest might be served by harmonizing and internationalizing the legal machinery, especially if it is done through private mechanisms, it may be difficult to get them to understand their self interests in this regard.

The proponents of new laws to restrict indecent material are likely to oppose the loss of sovereignty they perceive to be associated with international machinery and are most likely to focus their efforts to enact new legislation and to enlist the national prosecutors at the local, state or (at most) national levels. Indeed, the only group with significant political power likely to favor the establishment of new machinery are content originators interested in reducing the incidence of intellectual property infringement. They insisted on the inclusion of the Trade Related Intellectual Property appendix in the Uruguay Round of GATT (TRIPS Agreement), 525 and already have proposed stronger international machinery to enforce intellectual property rights. While they might support the idea of international institutions with broad jurisdiction, they are more likely to concentrate their efforts on specialized copyright enforcement machinery. Involving them in discussions over the proposed international criminal court would be a useful step. Also, broader support for internationalization of computer crimes might be enlisted for initiatives involving financial computer crimes.

\section{E. Harmonizing International Search and Seizure Law}

The most obvious way to harmonize search and seizure law, thus avoiding the kinds of problems described in The Cuckoo's $E g g,{ }^{526}$ is to negotiate additional treaties, along the lines of the judicial assistance treaties reviewed earlier in this Article, to countries not presently covered by them, and making sure that computer crimes are covered.527 This alternative would provide the greatest certainty and the clearest channels for exercise of search and seizure authority. On the other hand, the international treaty neat 207.

525. For a discussion of the TRIPS agreement, see McManis, supra note 519,

526. Clifford Stoll, The Cuckoo's Egg: Tracking A Spy Through the Maze of Computer Espionage (1989). For a further discussion of The Cuckoo's Egg, see supra note 430 and accompanying text.

527. Present U.S. policy is to expand mutual legal assistance treaties. 
gotiation process is slow and, because of differing positions of foreign countries, likely to have spotty effect. ${ }^{528}$

An alternative, though far more controversial, approach would be to exert raw power abroad. When U.S. authorities need evidence from computer facilities located outside the United States, they simply would go and get it. Under Verduga-Urquidez, the exclusionary rule would be inapplicable as long as the target of the search was not a U.S. citizen or resident alien, and therefore the evidence seized could be used in an American prosecution. ${ }^{529}$ This alternative is conceivable theoretically, ${ }^{530}$ but represents bad foreign policy and allows law enforcement authorities to decide what searches are appropriate. Nevertheless, brute force search and seizure in the GII context is not necessarily as intrusive or as expensive as the brute force search and seizure in Verdugo-Urquidez and some other notorious cases. It may be feasible in many instances for computer evidence located abroad to be accessed remotely by law enforcement authority. In some instances, the accessibility would vitiate privacy concerns and thus remove the material from search and seizure law all together. In other instances, some subterfuge or circumvention of security measures might be involved that arguably would be tantamount to a search if conducted under domestic law. It is, therefore, appropriate to understand the legal implications of a brute force search and seizure.

\section{Respective Roles of Civil and Criminal Law}

Differing levels of effectiveness of criminal and civil justice in-

528. See Senate Hearings, supra note 434, at 7 (prepared statement of Allen J. Kreczko) (explaining how some MLATs, such as ones in affect with Argentina, Spain and Uruguay, provide very broad assistance because they do not have dual criminality standards). On the other hand, the treaty with Jamaica contains a requirement that a request make a minimum showing that a criminal offense has been or is likely to be committed in any case in which criminal proceedings have not been instituted, in order to discourage fishing expeditions and to conform international assistance with Jamaican practice. Id.

529. United States v. Verdugo-Urquidez, 494 U.S. 259 (1990). For a discussion of the VerdugaUrquidez opinion, see supra notes 441-52 and accompanying text.

530. While this approach might seem absurd, the Supreme Court has validated kidnapping of suspects in foreign territory, which represents a comparable extension of U.S. power into the borders of a foreign sovereign. See generally Elizabeth Mcjimsey, Note, United States v. Alvarez-Machain: International Governmental Abductions, 41 U. KAN. L. REV. 119 (1993) (discussing governmental abductions of criminal suspects in Canada and Mexico, and reviewing implications of United States v. Alvarez-Machain, 504 U.S. 655 (1992), which held that district court had jurisdiction to try Mexican national who was kidnapped and brought to United States and that extradition treaty did not provide exclusive procedure). 
stitutions call into question the location of the boundary between civil and criminal law. Identifying matters that should fall within the scope of international criminal law requires application of the same policy considerations that influence national legislatures in deciding to criminalize conduct that theretofore had been purely a matter of contract, tort or private property. Ultimately, of course, criminalization of conduct is an intensely political matter and political decisionmaking is not always rational in the analytical sense. Nevertheless, it is useful to identify the factors that suggest criminalization. At the very least, they represent a framework within which political debate can proceed. Conduct should be criminalized when the costs of enforcing private rights infringed by that conduct are so high that persons injured by the conduct will not, as a practical matter, pursue legal remedies. Additionally, criminalization is appropriate when conduct jeopardizes the security of political institutions or economic infrastructures.

The first criterion, the high cost of enforcing private rights, can be subdivided into three elements: causation difficulties personal jurisdiction difficulties and difficulties enforcing judgments against assets. Thus, vandalism to a worldwide financial network would likely go unremedied if victims would have difficulty (1) establishing a causal link between their injury and the vandal's conduct, (2) establishing personal jurisdiction in courts convenient to them and (3) enforcing civil judgments against assets belonging to a vandal. In such a scenario, a strong case would exist for criminalizing the vandal's conduct.

The second criterion, risk to national or economic security, is most controversial and difficult to define. Conduct infringing the security of state institutions can be defined so broadly as to include simple political criticism. Moreover, conduct that threatens the institutions of one state may advance the interests of another state. Nevertheless, it is inevitable that nations will define as criminal certain conduct satisfying the first branch of this criterion, and thus the criterion cannot be ignored in developing a list of international crimes. The second branch of this criterion may engender less controversy but is imprecise in its boundaries. The traditional international crime of piracy warranted criminalization because it threatened the economic infrastructure of maritime commerce. International financial terrorism and large scale international financial fraud qualifies for criminalization on similar grounds. Beyond that, conduct that threatens the digital communications infrastructure should qualify for criminalization. This includes damaging 
routing tables or flooding the Internet with packets so as to prevent or to impede the movement of legitimate traffic. Moreover, such conduct also satisfies the first criterion because the probable difficulty of establishing causation with respect to individualized injury and of obtaining personal jurisdiction over the actor represents large transaction costs for enforcing private rights.

The vagueness of the criteria for criminalization substantially mirrors the vagueness of the empirical dividing line between crimes and civil wrongs. ${ }^{531}$ A pragmatic distinction between civil and criminal justice is the most appropriate one for defining new international crimes-and for explaining current definitions. Criminal justice involves the expenditure of public resources on detection, investigation, apprehension and prosecution; civil justice relies on private resources for the same purposes. Criminal justice involves incarceration as a potential remedy and justifies significant interference with the liberty of the accused, pending trial; civil justice relies upon economic sanctions. Criminal justice imposes penalties without regard to proof of loss occasioned by the wrongful conduct; civil justice (except for punitive damages) imposes economic sanctions only to the extent necessary to compensate victims for proven loss.

There is another alternative for responding to the dispute characteristics that otherwise would justify criminalization: establish an administrative agency with enforcement power. Consider consumer fraud, for example. It may be the case that someone would fraudulently offer services or products through the GII. The small amounts of money involved might make any particular defrauded consumer an unlikely plaintiff in a breach of contract or fraudulent misrepresentation action, and the prospects of such a civil action would be even less likely as the costs of litigation go up, as they surely would given the personal jurisdiction, service of process and choice of law problems discussed above. Practically speaking, no rational actor would retain foreign counsel and sue in a foreign court over a twenty-dollar fraud. Applicable class action rules also may make it difficult or impossible to aggregate victims into a feasible plaintiff class.

At the same time, however, criminalization may be unlikely, because the problem is not serious enough to warrant the attention of policymakers in a wide variety of countries or because the details of

531. See International Union, United Mine Workers v. Bagwell, 114 S. Ct. 2552, 2557 (1994) (discussing ambiguous distinction between criminal and civil contempt penalties for violating injunctions). 
the universal crime are difficult to agree on. In this situation, the most appropriate institutional solution may be the establishment of a specialized investigatory and enforcement institution authorized to seek relief for victims or to seek sanctions against the wrongdoer, or both. Such an institution could be public or private, national or international. While one is tempted to think in terms of a federal agency such as the Federal Trade Commission or a state agency such as the consumer-fraud unit of a state attorney general's office, many other possibilities exist. Just as private organizations modeled on ASCAP and BMI can be useful to enforce copyright in cyberspace, ${ }^{532}$ so also may such a private mechanism be appropriate to police consumer fraud. Nor need such an institution be strictly national in character. It could be international, established under the auspices of the United Nations, the World Trade Organization (if GATT is expanded to encompass consumer fraud in the services area) or some entirely new arrangement.

The institution's functions could include suing on behalf of one or more victims, ${ }^{533}$ or it could have the authority to enforce new duties established by statute. ${ }^{534}$ The institution could investigate apparent wrongdoing through the tools available in civil procedure, or it could exercise new investigatory powers granted by statute. It would make appropriate contacts with foreign governments and courts to arrange for service of process and generally prosecute the civil action. It similarly would undertake appropriate action to enforce any judgment. If arbitration were available as a forum, the institution could utilize arbitration just as it could utilize litigation in the courts where the defendant or plaintiff is located. Obviously, the point of such an arrangement is not to extend jurisdiction beyond what it otherwise would be or to tilt the criminalization question one way or another. Rather, the purpose would be to deal with the transaction costs of enforcement so as to create a realistic prospect of legal response to the wrongdoing.

\section{Conclusion}

The availability of new Internet technology does not automatically change legal doctrine. It may, however, change the incidence

532. See Henry H. Perritt, Jr., Property in Cyberspace, - U. ChI. Legal F. (forthcoming 1996).

533. See, e.g., Pa. Stat. Ann., tit. 43, $\$ 260.8$ (West 1992) (granting Pennsylvania Secretary of Labor authority to institute prosecutions and actions for alleged violations of Pennsylvania Wage Payment and Collection Law).

534. New statutory duties obviously would require a higher level of international agreement among governments. 
of cases falling on one side or the other of the lines drawn by legal doctrine. This may, in turn, lead to changes in the law. Clearly, World Wide Web technologies make it easier for someone to stay outside a jurisdiction and do harm inside the jurisdiction. At the same time, they also make it easier for the actor to remain relatively passive and to rely on someone else, perhaps in the same jurisdiction as the victim, to be the real cause of the victim's harm.

The technology does not change the likelihood that in-forum assets will exist, although by facilitating remote action, it may actually decrease the percentage of controversies in which in-forum assets exist. If one distributes a print publication, it is more likely that one will have a warehouse or other facility for inventory and copies in various jurisdictions than if one publishes by the World Wide Web server. Further, the GII does not impact the likelihood that a defendant will be physically present in the jurisdiction, except that by facilitating remote action, it increases the percentage of cases in which a defendant need not come to a jurisdiction or be nearby to act so as to cause harm. Finally, the technology makes communication tantamount to service of process in remote places much easier, although the law of service of process is adapting slowly to recognize electronic methods as good service. Absent revolutionary changes in property concepts, technology makes no difference in the susceptibility of its hardware to execution or forfeiture. ${ }^{535}$

Realizing the potential of the GII requires evolution of private and public international institutions so that the rules for allocating responsibility can be enforced effectively even against harmful transactions that cannot be localized to any particular state. Much uncertainty with respect to civil dispute resolution can be resolved by working out international arbitration agreements that not only would obligate suppliers of information and information infrastructure to arbitrate their disputes, but also would make the arbitration mechanism available to the third parties claiming injury from GII activities. Such an arbitration mechanism should include clear choice of law rules obligating arbitrators to apply trade custom and codes of good practice developed by industry bodies.

535. It would be interesting to speculate, however, about how plausibly modest changes in concepts of intangible property, for example intellectual property, might make it easier to execute against property interests of wrongdoers outside the jurisdiction. For example, one obtaining a judgment against $A$, a citizen of country $X$, might be entitled to execute against the intellectual property of $A$ located in Virginia. In effect, execution of the judgment would extinguish access copyright and transfer it to the judgment creditor. This would be, in some sense, comparable to garnishment except that a garnishee need not be found within the jurisdiction. 
The criminal arena is more difficult to deal with because private arbitration cannot supplant criminal law, and criminal jurisdiction is even more localized than civil jurisdiction. Nevertheless, broadened concepts of extraterritorial application of national criminal law, accompanied by formal and informal efforts to harmonize substantive law of computer crimes, may be used to insure against significant criminal activity involving the GII falling through the cracks. Over the longer run, it is appropriate to consider defining certain serious types of GII crimes, such as those involving computer terrorism, intellectual property infringement and large scale financial fraud or sabotage, as international crimes and granting jurisdiction over them to the proposed International Criminal Court.

This Article concludes that for cyberspace disputes, fewer changes are needed in civil jurisdiction than in criminal jurisdiction. Because international arbitration awards are nearly universally enforceable under the New York Convention, parties interested in providing a framework for meaningful relief in cyberspace can begin working on a comprehensive arbitration agreement to cover the most likely types of international disputes in cyberspace. As a part of that private framework, the parties can provide for the application of a specialized body of rules; these rules can also be developed through private institutions. There remain two problems, however, with this proposal. First, the existance of potential claimants who are not parties to the arbitration agreement, and second, potential wrongdoers who deliberately place themselves in jurisdictions not obligated to enforce arbitration awards. The third-party problem can be handled to some degree by making arbitration fair, well known and available on a consensual basis to third parties. Another solution is a U.S. Court for Cyberspace, an idea deserving of further examination. The second problem can be solved to some degree by recognizing the utility of enforcing judgments, including arbitration awards against obligations and including service obligations owed by persons within the reach of a sovereign obligated to enforce the judgment or arbitration award.

Finally, in the criminal arena, the need for physical presence of one subject to criminal trial, the lack of universal status for computer crimes and the unevenness of the extradition framework present several problems. These problems can best be addressed by making sure that at least some of the more serious computer crimes are brought within the jurisdiction of the proposed International 
Criminal Court now under discussion in the U.N. and supported by the American Bar Association. The greater difficulty of solving criminal jurisdiction problems, compared with civil jurisdiction problems, might actually militate in favor of the practical decriminalization of some harmful activities. 
XI. Appendix: International Computer Terrorism and the INFORMATION INFRASTRUCTURE ${ }^{536}$

\section{A. The Lure of Technology and the Willingness to Use It}

Extremist groups resort to political violence when they lack the power to achieve political objectives through nonviolent legal means. In an effort to attract the attention of the public, terrorists perpetrate their acts with the media at the forefront of their strategy, a calculus based on the assumption that access to the communication structure is directly related to power. ${ }^{537}$ The Global Information Infrastructure (GII) has the potential to be more pervasive than any other existing media or communications network; its value to the publicity-seeker is obvious. The GII, however, will also support financial and commercial transfers for consumers, businesses and countries, private and commercial information transfers (including research and academic pools), civil and regional infrastructure control and support, and governmental operations. These functions of the GII would make ideal targets for disrupting commercial transactions, upsetting social order and inciting fear; as it is integrated into larger global information designs, the value of the GII as a political target grows exponentially.

Considering that computers have become ubiquitous in modern society, it is not surprising that terrorists have occasionally targeted computer systems. For instance, a computer virus found at Hebrew University in Israel is thought to have been developed by the PLO. ${ }^{538}$ In Japan, groups have attacked the computerized control systems for commuter trains, paralyzing one major city for hours. ${ }^{539}$ Indeed, the Italian Red Brigade's manifesto specifies the destruction of computer systems and installations as an objective for "striking at the heart of the state." ${ }^{540}$ Terrorism is a rapidly evolving and responsive phenomenon: effective terrorist technology and tactics are sensitive to their target political cultures and have

536. This section was written by Neal A. Pollard, National Security Analyst, Strategic Assessment Center of Science Applications International Corporation (SAIC); B.A. (Political Science), B.S. (Mathematics), 1993, Oklahoma University; M.Litt. (International Security Studies), 1995, St. Andrews University, Scotland; $\mathrm{Ph} . \mathrm{D}$. candidate (International Relations), Georgetown University.

537. See Alex P. Schmid \& JanNy de GraAf, Violence as Communication: InSURGent TERRorISM AND THE WESTERn News MEDIA 9 (1982) (“[T] errorism and mass communication are linked .... Without communication there can be no terrorism.").

538. Phillip Fites et al., The Computer Virus Crisis 63 (1992).

539. Id.

540. Id. 
evolved at a pace commensurate with dominant military, commercial and social technologies. ${ }^{541}$

It stands to reason that as technology becomes more cost-effective to terrorists-that is, its availability and potential for disruptive effects rise while its financial and other costs go down-terrorists will become more technologically oriented in tactics and strategies. Twenty years ago, terrorist experts recognized that increasing societal reliance upon technology changes the nature of the threat posed by terrorists:

Commercial aircraft, natural gas pipelines, the electric power grid, offshore oil rigs, and computers storing government and corporate records are examples of sabotageprone targets whose destruction would have derivative effects of far higher intensity than their primary losses would suggest. ... Thirty years ago terrorists could not have obtained extraordinary leverage. Today, however, the foci of communications, production, and distribution are relatively small in number and highly vulnerable. ${ }^{542}$

International organized crime syndicates, particularly Asian syndicates, already use a spectrum of computer crimes, networks and fraud to support their activities. ${ }^{543}$ The Japanese Yakuza, Chinese secret societies and Vietnamese gangs operating in immigrant communities throughout the world incorporate computer technology as they collaborate with Latin American drug cartels (and in turn teach the new Central Asian and Transcaucasus gangs) on a wide range of efforts, even including launching their own satellite to ensure more secure communications. ${ }^{544}$ Computer crime could

541. For perspectives on how terrorist strategies are sensitive to evolving social and media cultures, see Terrorism and the Media (David Paletz \& Alex Schmid eds., 1992); see also Bruce Hoffman, Responding to Terrorism Across the TechNOLOGICAL SPECTRUM 30 (1994) (implying that "amateurization" of terrorism, resurgence of ethno-religious terrorism and evolution of "professional" terrorism have evolved fairly commensurately with diffusion or diminishing of centralized power in regions experiencing terrorism, and progressive accessibility of technology (both information technology as well as military technology) to general public).

The incorporation of information technology into the military-industrial complex, as well as the design of information warfare strategies, increases the attractiveness of computer technology to the terrorist. In the final days of the Cold War, NATO allies took seriously the premise that as warfare grows more electronic and dependent upon information technology, the vulnerabilities and risks of sabotage grow. Gerald Segal, Asians in Cyberia, WASH. Q., Summer 1995, at 13.

542. Grant Wardlaw, Political Terrorism 26 (1989) (quotation omitted).

543. Segal, supra note 541, at 13.

544. Id. 
well be the nexus that solidifies effective cooperation between international terrorism and global organized crime, particularly as criminal syndicates begin to operate in areas that are rife with political violence campaigns, such as in the former Soviet Union. Such areas of political instability provide an anarchical "order vacuum" which inhibits effective law enforcement. ${ }^{545}$

Computer technology offers new opportunities to terrorists with the above strategic concerns: in pursuing this modus operandi, a terrorist organization can reap low-risk, highly visible payoffs by attacking computer systems. Electronic vulnerabilities are often harder to guard than "traditional" vulnerabilities to terrorist attack, and countering governmental computer counter-terrorist measures would likely result in less loss of life. Unfortunately, Information Technology (I.T.) does not offer the same utility to states as it does to terrorists. Although the Soviet Union and other Communist authoritarian states believed in the Orwellian power of information technology to manage citizenry, there is much evidence suggesting that fundamentally, information technology empowers individuals and groups, threatening large centers of power. ${ }^{546}$ Therefore, the GII becomes the ideal tool for a terrorist campaign of propaganda and social destabilization, as "the small bands of extremists and irreconcilables that have always existed may become an increasingly potent force." ${ }^{547}$

\section{B. Defining Computer Terrorism: Tools and Targets}

Political terrorism is the systematic, deliberate use of actual or threatened physical violence toward non-military, non-governmental or internationally protected persons, in order to incite public fear and to destabilize society, and thus to intimidate or to coerce a population or policy toward a preconceived political objective. Computer terrorism is the nexus between criminal computer fraud

545. For a discussion of political instability and its effect on law enforcement, see Scott Anderson, Making a Killing: The High Cost of Peace in Northern Ireland, HARPER's, Feb. 1994, at 45-54 and Scott Anderson, Looking for Mr. Yaponchik: The Rise and Fall of a Russian Mobster in America, HARPER's, Dec. 1995, at 40-51.

546. Segal, supra note 541, at 5. It is important to note that democratic societies and free markets find uses for Information Technology (I.T.) which are decentralized in structure and application. Indeed, one reason I.T. flourishes in free-market democracies is because of its tendency to decentralize power. It will be interesting to observe what role I.T. plays when nations such as China reconcile free-market capitalism with totalitarianism.

547. Brian Michael Jenkins, International Terrorism: A New Mode of Conflict, in International Terrorism and WOrLd Security 13, 28 (D. Carlton \& C. Schaerf eds., 1975). 
or abuse, and the physical violence of political terrorism. Particularly in a legal sense, however, computer terrorism can be the intentional abuse of a computer system, network or component toward an end that supports or facilitates a terrorist campaign or action; in this case, the computer abuse would not necessarily result in direct violence against humans, although it may still incite fear.

Most terrorism scholars, when defining "political terrorism," would include physical violence as a necessary component; thus, many acts of criminal computer abuse would not be considered terrorist, if they do not result in direct physical violence. Adequately defining "political terrorism," however, is the Holy Grail of political violence scholarship. The semantic vacuum of a universally accepted comprehensive definition leaves room for considering computer abuse as a possible new facet of terrorist activity, provided that such abuse (1) is perpetrated to create a general climate of fear among a population; (2) contributes toward or facilitates physical violence against civilians, whether real or implied; (3) is in pursuit of a preconceived political objective; and (4) is intended for a wider audience. ${ }^{548}$ Indeed, to ignore computer abuse as a political crime, simply for the sake of academic purity, is impractical and dangerous.

In a computer society, there are two general methods by which a terrorist might employ a computer: when the computer is a target itself, or when it is the tool of a larger operation. The first method implies that a terrorist would target a computer system for sabotage, either electronic or physical, thus destroying or disrupting the system itself and any systems (computer or otherwise) dependent upon the targeted computer, and denying system availability. The second method, using the computer as a tool rather than as a target, implies that a terrorist would manipulate and exploit a computer system, alter or steal data, or force the computer to perform a function for which it was not meant, denying system integrity or confidentiality.

Societies and corporations are increasingly embedding computer information and communication systems within their infrastructures, presenting more numerous and diverse vulnerabilities to terrorists and criminals. Although it lacks the doomsday shadow of bio-chemical terrorism or the cataclysmic roar of nuclear terrorism, our increasingly computer-based society promises to be a fertile

548. See Anthony Clark Arend \& Robert J. Beck, International Law and THE USE OF FORCE 141 (1993) (enumerating similar characteristics). 
ground for terrorist tactical operations, ${ }^{549}$ perhaps more dangerous because of the little attention it receives in computer security analyses. 550 Nevertheless, the lives and physical security of citizens are becoming increasingly dependent upon mission-critical computer systems, such as those that operate mass transit systems, air traffic control systems, nuclear facilities, emergency telecommunications, electric power, hospitals and water supplies. ${ }^{551}$ The destruction or temporary denial of computer system control over these essential services would have tragic effects, compounded by the fear and panic incited by a terrorist attack.

The presence of computer systems in society also presents the danger of exploitation. The replacement of cash by credit and electronic funds transfer will open new oportunities for extortion. ${ }^{552}$ Furthermore, computer fraud, in the scale that large banks currently report monthly in their "losses to computer error or abuse" column, could fund a terrorist campaign without the money trail that leads back to a sponsor who would otherwise incur international sanctions or retaliation. ${ }^{553}$ Electronic funds transferred through a network of international banks makes money laundering easier than ever before. ${ }^{554}$ Terrorists can take advantage of the free flow of information in formulating their propaganda, tactics and strategies against a system, influential corporation or society, in pursuit of economic or political objectives, and societies with freedom of expression are particularly vulnerable to a systematic propaganda campaign embedded within public multimedia broadcasts.

Data terrorism is even more subtle. This involves pursuing

549. Richard Charles Clark, Technological Terrorism 145 (1980).

550. This lack of attention is perhaps due to the fact that most computer crimes are committed for monetary gain or pleasure, rather than for political objectives. See Bengt Angerfelt, Computer Crimes: A Study of Different Types of Offenses and Offenders, in IT SecurtT: The Need for International CoOperation (Proceedings of the Eighth IFIP International Conference, May, 1992) 463, 465-73 (Guy Gable \& William J. Caelli eds., 1993).

551. Clark, supra note 549, at 146.

552. Richard Clutterbuck, Terrorism, Drugs, \& Crime in Europe After 1992 114-16 (1990).

553. In one case of computer fraud in Singapore, $\$ 1.2$ million was untraceably lost in 49 seconds. Chew Teck Soon, ASEAN - Computer Crime and Corrective Action: A Status Report, in IT SeCurTr: The NeEd for International CoOperation, supra note 550 , at 23,27 . This is merely one instance. There are no valid statistics on losses to computer crime; annual losses have been reported ranging from $\$ 143$ million to $\$ 41$ billion. Donn B. Parker, Seventeen Information Security Myths Debunked, in Compurer SecurTt and Information INTEGRTTY (Proceedings of the Sixth IFIP International Conference, May, 1990) 363, 363 (Klaus Dittrich et al., eds., 1991).

554. Clutterbuck, supra note 552, at 182. 
political goals by manipulating public behavior under specific circumstances, causing public misinterpretation of data through selectively falsified information. ${ }^{555}$ Computer-controlled manifests for arms shipments or nuclear consignments could quietly-and quite untraceably-be rerouted through the efforts of a single person..$^{556}$ Additionally, some government systems are no safer electronically than commercial systems. ${ }^{557}$ The possibilities of espionage or access to police, intelligence and operations files are a significant threat. One of the more spectacular cases of illegal access was a sixteen year-old British "hacker" with the Internet name "Datastream," who acquired certain of South Korea's nuclear secrets through the Griffith Air Force Base in New York. ${ }^{558} \mathrm{He}$ also obtained information on North Korea's missile firing sites, aircraft design and U.S. agents in North Korea. In the end, over one million government passwords were compromised. ${ }^{559}$ Activities such as this can do more than support terrorism or contribute to social instability; they can affect regional balances of power.

\section{Terrorist Strategy and Political Character}

Digital globalization and the GII may endow global computer and telecommunications systems with elements of political authority as well as with the ability to influence cultures, ${ }^{560}$ which could present such systems as potential "strategic" targets, rather than simply the "tactical" targets mentioned above. Global corporations are integrating the planet in the course of doing international business, and the extraordinary digital machine has embedded itself into our cities, societies and commerce. No political ideology or economic theory, however, has yet evolved to explain or to explore its implications. ${ }^{561}$ Digital technology continues to outpace political and economic policy and may perhaps even contribute to an erosion of state sovereignty as leaders cannot make policy regarding

555. F. Bertil Fortrie, IT Crime: An Intelligence Report, in IT Security: The NeEd fOr INTERNATIONAL COOPERATION, supra note 550, at 325, 329.

556. Richard Hackworth, Contingency Planning: Managing the External Impacts of System Security Failures, in COMPUTER SECURITY AND INFORMATION INTEGRITY, supra note 553 , at $181,183$.

557. Clutterbuck, supra note 552, at 115.

558. Segal, supra note 541, at 12.

559. Id.

560. This thesis is explored in Slavko Splichal et al., Information Society and Crvil Society (1994).

561. For a cross-section of social, political, economic and technical perspectives of digital globalization, see Joshua Meyrowitz, No Sense of Place (1985), Darrell Delamaide, The New Superregions of Europe (1994) and Richard Barnet \& John Cavanagh, Global Dreams (1994). 
the activity of "foreign" corporations when those corporations have already easily and fluidly permeated national borders. ${ }^{562}$

As state sovereignty is transformed, huge urban centers rise in international importance, and various non-governmental organizations and multi-national corporations gain degrees of political influence, computer information transfer systems will acquire more direct roles in political and economic dynamics. Political malcontents then will form strategies against institutions that have political character. Digital information systems are the infrastructures that support the globalization efforts of non-governmental organizations, multi-national corporations and other international institutions. Thus, it stands to reason that extremist groups opposed to such efforts would target these systems for the political targets they represent, the organizations whose critical day-to-day workings they support, and the direct and indirect effects that disrupting such systems would have on regional policy, commerce, civil security and order, and social infrastructures.

\section{Target Value}

People will always be the most effective targets for terrorists. Yet a terrorist usually would rather scare-and thus influencepeople than kill them. This is most efficiently accomplished by attacking targets that affect the largest number of people, thus attracting publicity. An example of such an attack is the April 10, 1992, IRA bombing in the Square Mile of London: ${ }^{563}$ The attack killed three people, but its intent was not to kill. It was an attack at the financial center of Europe, causing a severe effect-electronic, financial and psychological-on the world's business community.

If the terrorist views political violence as a form of mass communication, attacking an information infrastructure may eliminate the need to incorporate the "traditional" media industry as an intermediary in the terrorist strategy. Systems within the GII make ideal targets for generating publicity for a number of reasons. First, the GII acquires its political character precisely because of the number of humans it can touch: in theory either bringing them together, or alienating them and even provoking political instability. Second, digital communication's pervasiveness in industrial society makes it easily accessible. Finally, our increasing social and commercial reliance upon digital technology casts its accessibility as a vulnerability

562. Barnet \& CaVANaGH, supra note 561, at 19.

563. Alan Reed, Computer Disasters: The Impact on Business in the 1990s, in IT SeCurity: The NeEd for International CoOperation, supra note 550, at 13, 17. 
to personal security and civil order. When one considers the importance of the social and commercial functions that are supported by interconnected computer systems, our reliance upon such systems means the damage done in disrupting a networked system would far outweigh the effort spent in disruption. Additionally, due to the ease of access, little risk is posed to the perpetrator.

In addition to these advantages of targeting computer systems, there is the psychological impact on users. The "user" of the computer is rarely familiar with security aspects, but represents the vast majority of those directly interacting with the computer. Indeed, the competition in the computer industry to build faster, more "user-friendly" systems usually places effective but slow and complex security measures at a disadvantage, especially when they do not produce immediate returns on investment. ${ }^{564}$ Even those who do implement extensive computer security systems often fail to close the gap between security theory and security practice. System managers who religiously follow the most advanced electronic security programs occasionally fail to account for the human factor and are thus prone to a dangerous Maginot Line mentality. ${ }^{565}$

\section{E. Policy and Legislation: European Lessons in International Cooperation}

International computer crime involves issues that the law is barely equipped to grasp. ${ }^{566}$ Internationally, law has had an equally difficult history in confronting political crimes. ${ }^{567}$ With the possibility of computer terrorists seeking political objectives, legal regimes must be formulated that effectively deal, on an international scale, with politically motivated computer abuse, destruction or the physical violence of computer terrorism. Regulatory measures that seek to counter computer terrorism should address the value of information as a coveted product, as well as detection and investigation of such crimes. More importantly, however, such measures

564. Donald Davies, Information Security-Theory and Practice, in INFORMATION SECuRITY (Proceedings of the Seventh IFIP International Conference, May, 1991) 462 (D.T. Lindsay \& W.L. Price eds., 1992).

565. An example is in the British House of Commons: one system there carries a program which regularly prompts the user to change his or her password. Users were instructed simply to add a " 1 " onto the end of their passwords each time, thus eliminating the pesky need to memorize yet another password.

566. M.R. Jones, Dealing with Compruter Abuse-The Need for an International Approach, in IT SecurtT: The NeEd for InTERnational CoOperation, supra note 550 , at 475 . 901.

567. Abraham Sofaer, Terrorism and the Law, Foreign AfF., Summer 1986, at 
must be constructed mindful of the international nature of both computer crime and political terrorism. Although such international treaties and regimes result from national efforts, ${ }^{568}$ such efforts can be modeled on existing international structures, with the intent to integrate and to evolve within international cooperative arrangements.

Targets of political crime can be "hardened" and risks averted, by a politically responsible information infrastructure policy. We should guide the construction and connection of digital information systems, recognizing that computer crime can indeed enter the arena of political crime. Such a policy would concentrate security measures on the value of information systems and the product they carry, rather than focusing only on the mechanisms of protection. This security analysis would yield the potential value of the system to the strategies and tactics of politically motivated computer abuse, as well as the system's "political character," or its ability to influence masses of people.

Effectively legislating against computer terrorism will mean the union of all the legislative difficulties inherent in proscribing computer crime with those encountered in proscribing political crime. Countering computer crime involves an area of law that is presently ill-equipped to deal with the nature and range of offenses, ${ }^{569}$ because technological innovation thwarts a traditional regulatory regime which has become divorced from technological and commercial realities. One must also bear in mind that political crimes differ from other crimes in that objectives and gains are occasionally abstract and difficult to determine, and the perpetrators are seldom the sole "beneficiaries." For this reason, motives behind political crimes are often difficult to understand by those excluded from the extremist's views. Furthermore, complications arise in legislating against political crimes on an international scale, since laws proscribing political crimes are subjective opinions of the indigenous political system which fostered them.

To this union of obstacles will be added the further difficulties of detection and investigation, as much computer crime goes unnoticed until its effects are apparent. Furthermore, many of these crimes go unreported, particularly in the commercial sector, so as

568. Jones, supra note 566 , at 489.

569. A good example is the area of data privacy. See, e.g., Wayne Madsen, Data Privacy: Legislation and Intelligence Agency Threats, in COMPUTER SECURTY AND INFORMATION INTEGRTTY, supra note 553, at 297. 
not to embarrass or to erode consumer confidence. 570 . While it is not difficult to detect the bombing of a computer installation, an undetected or unreported illegal funds transfer or arms consignment re-routing would confound attempts to counter the act, to establish sponsorship, to investigate and prosecute the perpetrators, and-in the case of foreign sponsorship-to censure the sponsor government.

The regulatory task at hand requires extensive international cooperation. In legislation countering computer crime as well as international terrorism, the territorial principle cannot be the key determinant of jurisdiction. The principle of universality would certainly be more relevant, finding precedents in international law proscribing crimes such as maritime piracy, genocide, slave trading and hijacking. ${ }^{571}$ International cooperation demands clear definitions of what is criminal at the national and international levels, as well as international coordination of deterrent and repressive measures. ${ }^{572}$ It is still incumbent upon national governments, however, to pass appropriate legislation and to seek effective international agreements before such an international cooperative structure can be realized. ${ }^{573}$

The European Union is the ideal forum in which to pioneer such international initiatives, in light of its tested unifying mechanisms, its degree of industrialization of the member states, and the articulated intentions of member states and the European Union as a whole to build an information infrastructure. The E.U. countries have the most ambitious program of information infrastructure development, reflecting the call for electronic integration to facilitate real economic and political integration. ${ }^{574}$ Having proposed a $\$ 150$ billion project that will rival or exceed the United States' National Information Infrastructure (NII), the European Union intends to meet the demands of a strengthening economic union for more efficient, powerful and versatile information technology systems. ${ }^{.575}$ The E.U. slice of the GII will resemble other regional contributions in communication growth, personal computer proliferation,

570. Parker, supra note 553, at 364.

571. Crimes such as these, although perpetrated by individuals, are frequently the product of a conspiracy or group, with a legal personality somewhere between individuals and nation-states. Anthony Clark Arend, Address at American Bar Association Conference on Terrorism and National Security (Oct. 19, 1995).

572. Jones, supra note 566, at 487.

573. Id. at 489.

574. G-7 Information Society Conference Theme Paper (presented in Brussels, Feb. 24, 1994).

575. Id. 
greater connectivity, newer technology and digital integration of voice, data, video and graphics technology. ${ }^{576}$

The European Union will face unique problems. Member states do not have the luxury, as the United States does, of formulating national legislation without carefully considering its place within an international framework. This fact, and the sheer proposed size of the E.U. Information Society, means that E.U. solutions could be ideally internationalized, providing a good model on which other countries can construct their NII policies and procedures. Unfortunately, the European Union itself has far to go. Despite the E.U.'s initiatives, Europe must accommodate different languages, different laws, and, in some cases, drastically different judicial systems. The potential risks posed in digital globalization, including the vulnerability to political violence, will only be exacerbated by the legal, political, social and economic problems that will certainly complicate the process of future unionization.

Traditional political borders will not lose all relevance within globalized digital systems, as they can be employed as "tripwires" to assist in the geographical tracking, apprehension and prosecution of computer criminals. The Schengen countries 577 of the European Union lack even these modest barriers. Terrorists targeting or using computers can exploit areas still under the province of individual state sovereignty within the European Union (such as intelligence gathering, arms and nuclear materials control, encryption standards and the military complex) while finding safe haven in the free movement across borders throughout Western Europe. After possible full unionization, or as the Schengen Accord gains signatories, terrorists will need to penetrate only one frontier to access half a continent populated by varied peoples and cultures, including many immigrants who look beyond E.U. borders to their homeland.

These problems inherent in the European Union will have analogies common to any globalization initiative. Currently, the Organization of Economic Cooperation and Development (OECD), the Council of Europe and the U.N. all advocate international cooperation in legislating against computer and political crimes, and such cooperation would extend to deterring crime to

576. $I d$.

577. The Schengen Accord of 1985 provides for the total abolition of personal checks at common national borders among signatory states. Schengen Accord of 1985, 30 I.L.M. 68 (1991). 
the extent permitted under applicable national laws and treaties. ${ }^{578}$ These deterrence measures would include better systems for frontier checks and searches, pooling information and intelligence, raising international awareness of national preventative measures, smoother extradition procedures, national prosecution of foreign judgments in cases where extradition is impossible, and harmonization of laws addressing computer and political crimes. ${ }^{579}$ Together, these proposals help to close national legal loopholes that so often render treaties and conventions impotent. ${ }^{580}$

Changes are also needed in financial and commercial lawsespecially in the G-7 and other wealthy industrialized countries-to confront the spectrum of computer abuse available to criminals, political or otherwise. These changes include responsible law enforcement access to digital transfers, encryption registration and key escrow, and other regulatory measures designed to counter computer exploitation by terrorists and organized criminals. Effective ideas have been proposed within the European Union, but were thwarted by the simple fact that many E.U. countries are eager to retain as many vestiges of national sovereignty as possible. One example is a German vision for Europol: a law-enforcement organization that would combine the current communications and intelligence functions of Interpol with the territorial enforcement and apprehension powers of national police forces in Europe. Unfortunately, the court that would provide the legislative foundation of Europol-the European Court of Justice (ECJ) -is still too racked by political turf battles among member states to achieve the legal power of consensus needed to make Europol an effective law enforcement body. ${ }^{581}$ Until this transnational court becomes acceptable as a criminal court, efforts at true international integration will be as ceremonial and impotent as existing European legal regimes to counter international terrorism. ${ }^{582}$

To be most effective, law should take on the same dimensions as the actors it seeks to address. The Internet, however, has no geographical bounds, no formal political structure, no cultural con-

578. Jones, supra note 566 , at 487 .

579. Id.

580. This impotence is perhaps best embodied in the European Convention for the Suppression of Terrorism (ECST), a Council of Europe legal regime specifically constructed to close loopholes in previous treaties and conventions to counter terrorism. Clutterbuck, supra note 552, at 123. Unfortunately, the Convention did little to close loopholes, and even created its own. Id.

581. Sofaer, supra note 567, at 902 .

582. Id. at 901-02. 
straints; actually, no one is sure exactly how many people access it or who pays for it. Its technology has intractably embedded itself into our cities, societies and commerce, but no political ideology or economic theory has yet evolved to explain or explore its implications. Such a global machine has almost incomprehensible dimensions, connecting all the facets and flaws of mankind. Indeed, digital globalization may be the first human effort that is truly international in scope and intent, and it presents a potent opportunity in the evolution of the international legal system. Therefore, terrorism targeting the GII is also necessarily global in character. Perhaps in the future, supranational organizations will be in place to better combat this threat. As the current legal order has as its base the sovereignty of the nation-state, however, international coordination is vital to combating computer terrorism. 